\title{
Methyl lodide Sorption by Reduced Silver Mordenite
}

R. D. Scheele

L. L. Burger

C. L. Matsuzaki

June 1983

Prepared for the U.S. Department of Energy under Contract DE-AC06-76RLO 1830

Pacific Northwest Laboratory Operated for the U.S. Department of Energy by Battelle Memorial Institute 


\title{
DISCLAIMER
}

This report was prepared as an account of work sponsored by an agency of the United States Government. Neither the United States Government nor any agency thereof, nor any of their emplayees, makes any warranty, express or: implied, or assumes any legal liability or responsibility for the accuracy, completeness, or usefulness of any information, apparatus, product, or process disclosed, or represents that its use would not infringe privately owned rights. Reference herein to any specific commercial product, process, or service by trade name, trademark, manufacturer, or otherwise, does not necessarily constitute or imply its endorsement, recommendation, or favoring by the United States Government or any agency thereof. The views and opinions of authors expressed herein do not necessarily state or reflect those of the United States Government or any agency thereof.

\author{
PACIFIC NORTHWEST LABORATORY \\ operated by \\ BATTELLE \\ for the \\ UNITED STATES DEPARTMENT OF ENERGY \\ under Contract DE-AC06-76RLO 1830
}

\begin{tabular}{|c|c|}
\hline \multirow{2}{*}{\multicolumn{2}{|c|}{ Printed in the United States of America }} \\
\hline & \\
\hline National Technical Intormation Service & Available from \\
\hline \multirow{3}{*}{\multicolumn{2}{|c|}{$\begin{array}{l}\text { United States Department of Commerce } \\
5285 \text { Port Royal Road } \\
\text { Springfield, Virginia } 22761\end{array}$}} \\
\hline & \\
\hline & \\
\hline \multirow{2}{*}{\multicolumn{2}{|c|}{$\begin{array}{l}\text { Nis Price Codes } \\
\text { Microfiche A01 }\end{array}$}} \\
\hline & \\
\hline \multicolumn{2}{|c|}{ Printed Copy } \\
\hline & Price \\
\hline Pages & Codes \\
\hline $001-025$ & $\mathrm{~A} 02$ \\
\hline $026-050$ & $\mathrm{~A} 03$ \\
\hline $051-075$ & $\mathrm{~A} 04$ \\
\hline $076-100$ & A05 \\
\hline $101-125$ & A06 \\
\hline 126.150 & $A 07$ \\
\hline $151-175$ & $\mathrm{~A} 08$ \\
\hline $176-200$ & $A 09$ \\
\hline 207.225 & $A 010$ \\
\hline $226-250$ & A011 \\
\hline 251.275 & $\mathrm{~A} 012$ \\
\hline $276 \cdot 300$ & $A 013$ \\
\hline
\end{tabular}




\section{4}

PNL -4489

UC -70

METHYL IODIDE SORPTION BY

REDUCED SILVER MORDENITE
R. D. Scheele
L. L. Burger
C. L. Matsuzaki

June 1983

Prepared for the U.S. Department of Energy under Contract DE-AC06-76RL0 1830 


\section{CONTENTS}

ACKNOWLEDGMENTS $\ldots \ldots \ldots \ldots \ldots \ldots \ldots \ldots \ldots \ldots \ldots \ldots \ldots \ldots \ldots \ldots \ldots \ldots \ldots \ldots \ldots \ldots$

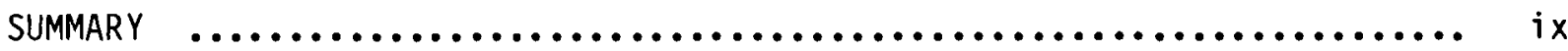

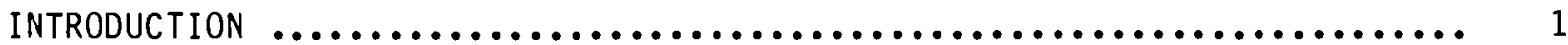

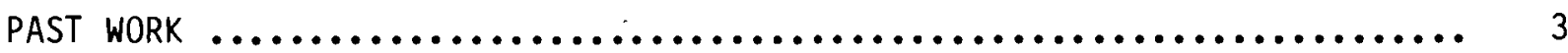

FACTORS INFLUENCING IODINE SORPTION $\ldots \ldots \ldots \ldots \ldots \ldots \ldots \ldots \ldots \ldots \ldots \ldots \ldots$

ZEOLITE STRUCTURE $\ldots \ldots \ldots \ldots \ldots \ldots \ldots \ldots \ldots \ldots \ldots \ldots \ldots \ldots \ldots \ldots \ldots \ldots$

MOLECULAR SIEVE EFFECTS $\ldots \ldots \ldots \ldots \ldots \ldots \ldots \ldots \ldots \ldots \ldots \ldots \ldots \ldots \ldots \ldots \ldots$

HYDROGEN PRETREATMENT OF AgZ $\ldots \ldots \ldots \ldots \ldots \ldots \ldots \ldots \ldots \ldots \ldots \ldots \ldots \ldots \ldots \ldots$

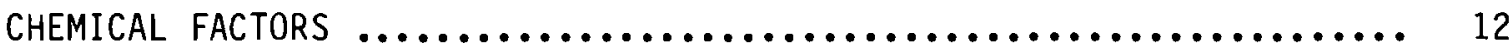

Iodine Sorption $\ldots \ldots \ldots \ldots \ldots \ldots \ldots \ldots \ldots \ldots \ldots \ldots \ldots \ldots \ldots . \ldots . \ldots . \ldots$

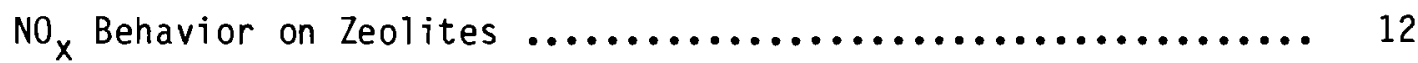

Thermodynamic Considerations $\ldots \ldots \ldots \ldots \ldots \ldots \ldots \ldots \ldots . \ldots \ldots$

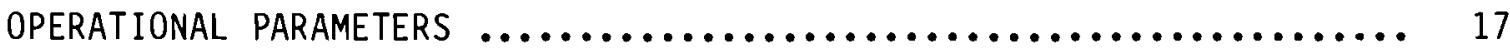

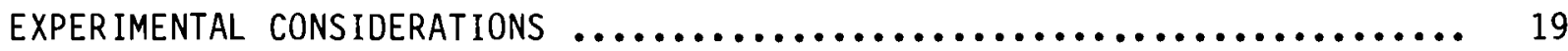

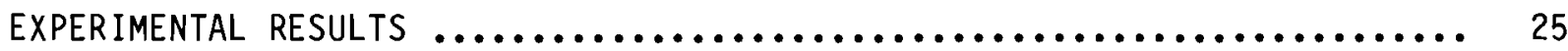

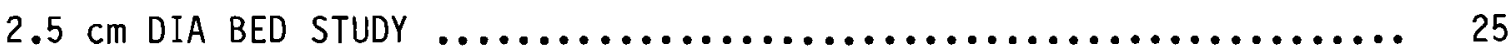

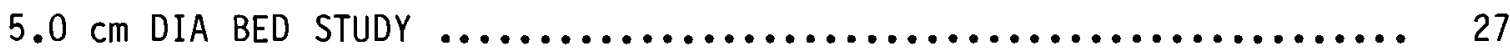

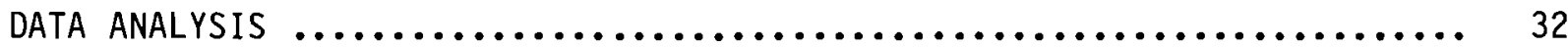

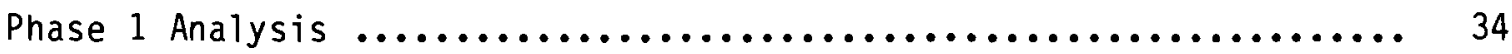

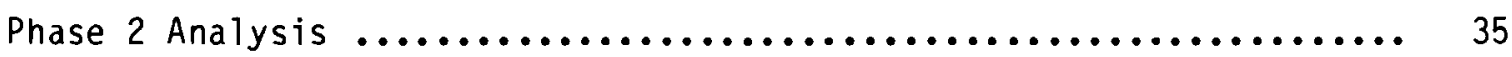

CONCLUSIONS AND RECOMMENDATIONS $\ldots \ldots \ldots \ldots \ldots \ldots \ldots \ldots \ldots \ldots \ldots \ldots \ldots \ldots \ldots$

REFERENCES $\ldots \ldots \ldots \ldots \ldots \ldots \ldots \ldots \ldots \ldots \ldots \ldots \ldots \ldots \ldots \ldots \ldots \ldots \ldots \ldots \ldots . \ldots \ldots \ldots$

APPENDIX A $-\mathrm{CH}_{3}$ I LOADING CURVES $\ldots \ldots \ldots \ldots \ldots \ldots \ldots \ldots \ldots \ldots \ldots \ldots \ldots \ldots \ldots \ldots$ 
$\underline{\text { FIGURES }}$

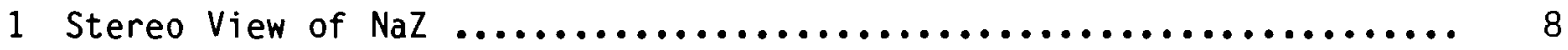

2 Scanning Electron Micrograph of Iodine-Loaded $\mathrm{Ag}^{\circ} \mathrm{Z}, \ldots \ldots \ldots \ldots \ldots, 11$

3 Experimental Apparatus for $\mathrm{CH}_{3} \mathrm{I}$ Capture by Silver Mordenite $\ldots . . . .20$

4 Phase 1 Analysis: The Effect of Temperature on $\mathrm{CH}_{3} \mathrm{I}$ Capture by $\mathrm{Ag}^{\circ} \mathrm{Z}$ at Face Velocities of 3.75 and $15 \mathrm{~m} / \mathrm{min} \ldots \ldots \ldots \ldots \ldots \ldots \ldots \ldots \ldots . \ldots . \ldots . \ldots$

5 Phase 1 Analysis: The Effect of Face Velocity on $\mathrm{Ag}^{\circ} \mathrm{Z}$ at 86

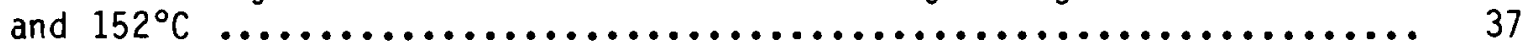

6 Phase 1 Analysis: The Effect of $\mathrm{NO}$ on $\mathrm{CH}_{3} \mathrm{I}$ Capture by $\mathrm{Ag}^{\circ} \mathrm{Z}$ at Face Velocities of 3.75 and $15.0 \mathrm{~m} / \mathrm{min} \ldots \ldots \ldots \ldots \ldots \ldots \ldots . \ldots . \ldots . \ldots . \ldots$

7 Phase 1 Analysis: The Effect of $\mathrm{NO}_{2}$ on $\mathrm{CH}_{3} \mathrm{I}$ Capture by $\mathrm{Ag}^{\circ} \mathrm{Z}$

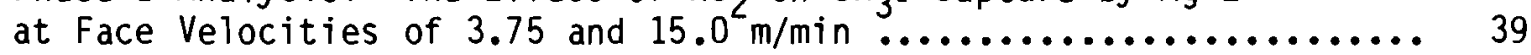

8 Phase 2 Analysis: The Effect of Temperature on $\mathrm{CH}_{3} \mathrm{I}$ Capture

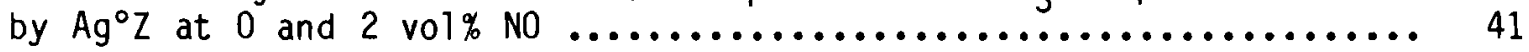

9 Phase 2 Analysis: The Effect of $\mathrm{NO}$ on $\mathrm{CH}_{3}$ I Capture by $\mathrm{Ag}^{\circ} \mathrm{Z}$ at Face Velocities of 3.75 and $15.0 \mathrm{~m} / \mathrm{min} \ldots \ldots \ldots \ldots \ldots \ldots \ldots . \ldots . \ldots . \ldots . \ldots$

10 Phase 2 Analysis: The Effect of $\mathrm{NO}_{2}$ on $\mathrm{CH}_{3} \mathrm{I}$ Capture by $\mathrm{Ag}^{\circ} \mathrm{Z}$

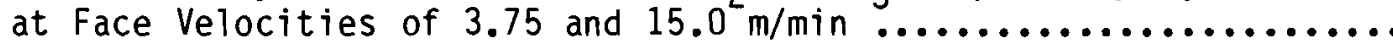

11 Phase 2 Analysis: The Effect of Temperature on $\mathrm{CH}_{3} \mathrm{I}$ Capture by $\mathrm{Ag}^{\circ} \mathrm{Z}$ at Face Velocities of 3.75 and $15.0 \mathrm{~m} / \mathrm{min} \ldots \ldots \ldots \ldots \ldots \ldots$

12 Phase 2 Analysis: The Effect of Face Velocity on $\mathrm{CH}_{3}$ I Capture by $\mathrm{Ag}^{\circ} \mathrm{Z}$ at 85,152 , and $200^{\circ} \mathrm{C}$ 


\section{TABLES}

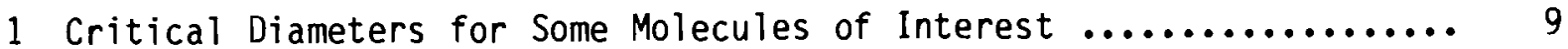

2 Reaction Free Energies for Some Possible Reactions in $\mathrm{Ag}^{\circ} \mathrm{Z}$........ 14

3 Operating Parameters for $2.5 \mathrm{~cm}$ Dia Bed $\ldots \ldots \ldots \ldots \ldots \ldots \ldots \ldots \ldots \ldots . \ldots \ldots$

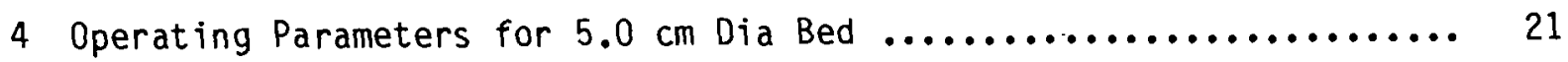

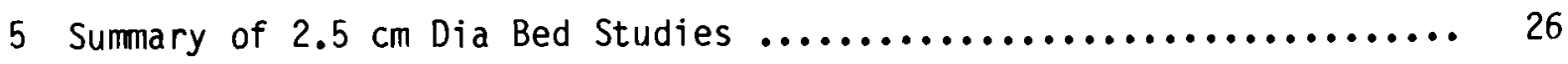

6 Summary of $5.0 \mathrm{~cm}$ Dia Bed Studies $\ldots \ldots \ldots \ldots \ldots \ldots \ldots \ldots \ldots \ldots \ldots \ldots . \ldots \ldots$

7 Summary of Iodine Loading by Bed Segment $\ldots \ldots \ldots \ldots \ldots \ldots \ldots \ldots \ldots$

8 Full Model ANOVA for Phase 1 Analysis ..................... 33

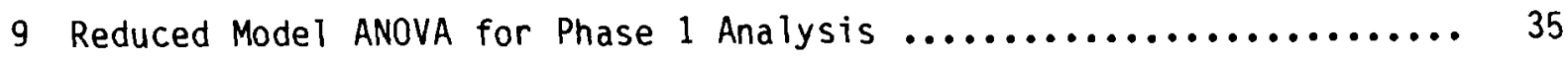

10 Reduced Model ANOVA for Phase 2 Analysis ................... 40 


\section{ACKNOWLEDGMENTS}

We would like to thank G. F. Piepel and M. W. Bowen for their help in designing the experimental plan and performing the statistical analysis of the data, F. T. Hara and A. W. Lautensleger for their analytical help, L. D. Maki for typing the report, and S. E. King for her editorial advice. 
.

.

$\therefore$ 


\section{SUMMARY}

At the Pacific Northwest Laboratory (PNL), we performed two sets of experiments to determine the effects of pertinent operational parameters and gas compositions on organic radioiodine [in particular methyl iodide $\left(\mathrm{CH}_{3} \mathrm{I}\right)$ ] capture by silver mordenite $(\mathrm{AgZ})$. In the first set of experiments, we studied the effects of 1) hydrogen pretreatment of AgZ, 2) change in particle size of $\mathrm{AgZ}$, and 3) the presence of water in the gas phase. In the second set of experiments we evaluated on a semi-quantitative basis the effects of nitric oxide ( $\mathrm{NO}$ ), nitrogen dioxide $\left(\mathrm{NO}_{2}\right)$, superficial face velocity, and temperature on $\mathrm{CH}_{3} \mathrm{I}$ capture by reduced (hydrogen pretreated) silver mordenite $\left(\mathrm{Ag}^{\circ} \mathrm{Z}\right)$.

These studies have shown that $\mathrm{AgZ}$, especially $\mathrm{Ag}^{\circ} \mathrm{Z}$, is an effective trap for $\mathrm{CH}_{3} \mathrm{I}$. However, its effectiveness varies with changes in operational parameters and is affected by other gases found in the process off gas of a nuclear reprocessing plant. Optimum trapping efficiency was achieved with $\mathrm{Ag}^{\circ} \mathrm{Z}$ rather than $\mathrm{AgZ}, 20-40$ mesh $\mathrm{Ag}^{\circ} \mathrm{Z}$ rather than $0.16 \mathrm{~cm}$ extrudate, moisture in the gas stream, higher temperatures up to $200^{\circ} \mathrm{C}$, absence of $\mathrm{NO}$, and lower superficial face velocities down to $3.75 \mathrm{~m} / \mathrm{min}$. Additionally, $\mathrm{CH}_{3} \mathrm{I}$ can be converted to elemental iodine $\left(\mathrm{I}_{2}\right)$ in the presence of $\mathrm{NO}$ or $\mathrm{NO}_{2}$ by controlling the operational parameters. Since $\mathrm{I}_{2}$ is easier to trap than organic iodides, this should improve trapping efficiency. 
, 


\section{INTRODUCTION}

Radioiodine arises from the generation of electricity by nuclear power. Because iodine-131 has such a short half-life ( 8 days), its release must be controlled for only 200 days. Iodine-129, however, with a half-life of $1.6 \times$ $10^{7}$ years, is still present in significant amounts at 200 days. The primary control point for radioiodine in the nuclear fuel cycle is at a nuclear fuel reprocessing plant (FRP). The principal release form is elemental iodine $\left(I_{2}\right)$; however, organic iodides are produced by reactions with organic contaminants in the dissolver off-gas and vessel vent systems. The predominant compound formed by these reactions is methyl iodide $\left(\mathrm{CH}_{3} \mathrm{I}\right)$, which may amount in some systems to several percent of the total iodine in the process off gas (POG).

Various technologies have been developed for the capture of radioiodine. Included in these are caustic scrubbing, mercuric nitrate-nitric acid scrubbing, hyper-azeotropic nitric acid (20-22 M) scrubbing, and sorption by silvercontaining solids. With each the organic iodides are trapped with varying degrees of success. One of the more promising technologies is capture by hydrogen-reduced silver mordenite $\left(\mathrm{Ag}^{\circ} \mathrm{Z}\right)$, which has been demonstrated by Thomas et al. (1977) to trap $I_{2}$ more efficiently than ionic silver mordenite (AgZ).

This report describes the results of an evaluation of the effects of selected dissolver off-gas constituents, temperature, and face velocity on the capture of $\mathrm{CH}_{3} \mathrm{I}$ by $\mathrm{Ag}^{\circ} \mathrm{Z}$. 


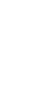




\section{PAST WORK}

Few workers have evaluated $\mathrm{Ag}^{\circ} \mathrm{Z}$ as a trapping agent for volatilized iodine species. $\mathrm{Ag}^{\circ} \mathrm{Z}$ was initially suggested and evaluated at the Idaho National Engineering Laboratory (INEL) for elemental iodine capture. Thomas et al. (1977) found that $\mathrm{Ag}^{\circ} \mathrm{Z}$ was superior to $\mathrm{AgZ}$ in its capacity for $\mathrm{I}_{2}$ removal. This was confirmed by our studies (Wiemers 1978; Wiemers and Scheele 1979; Scheele, Matsuzaki, and Burger 1981; Scheele 1981). Following this work, Oak Ridge National Laboratory (ORNL) also began a program to evaluate $\mathrm{Ag}^{\circ} \mathrm{Z}$ as a trap for organic iodides (Jubin 1980, 1982).

In INEL's final document on their silver mordenite studies, Murphy, Staples, and Thomas (1977) described their results on elemental iodine removal by $\mathrm{Ag}^{\circ} \mathrm{Z}$ :

- Elemental iodine loading of $\mathrm{Ag}^{\circ} \mathrm{Z}$ is about twice that of $\mathrm{AgZ}$; loadings of $171 \pm 17 \mathrm{mg} I / \mathrm{g} \mathrm{Ag}^{\circ} \mathrm{Z}$ are possible from simulated dissolver off-gas streams (DOG).

- NO has a positive effect on iodine loading.

- $\mathrm{NO}_{2}$ has a negative effect on iodine loading.

- Water vapor up to $2.4 \times 10^{-3}$ mole $\mathrm{H}_{2} \mathrm{O} / \mathrm{L}$ has little or no effect on iodine loading.

- Temperatures between 100 and $250^{\circ} \mathrm{C}$ have little or no effect on iodine loading.

INEL workers used a $5 \mathrm{~cm}$ dia $\times 15 \mathrm{~cm}$ deep bed of 10-20 mesh $\mathrm{Ag}^{\circ} \mathrm{Z}$, a face velocity of $15 \mathrm{~m} / \mathrm{min}$, a bed temperature of $150^{\circ} \mathrm{C}$, an iodine concentration of $1.2 \times 10^{-5} \mathrm{~mole} / \mathrm{L}$, and a termination retention factor (RF) of $10^{3}$ to $10^{4}$. The $\mathrm{Ag}^{\circ} \mathrm{Z}$ was prepared by batch treatment at $500^{\circ} \mathrm{C}$ for 24 hours. They prepared $\mathrm{AgZ}$ by ion exchange of sodium mordenite ( $\mathrm{NaZ}$ ).

In the early work performed by $\mathrm{PNL}$, we studied the effects of carrier gas composition, temperature, and zeolite pretreatment on $\mathrm{CH}_{3} \mathrm{I}$ capture by $\mathrm{AgZ}$ with these results: 
- $\mathrm{CH}_{3} \mathrm{I}$ capture was equivalent with either nitrogen or air as the carrier gas.

- Increasing the temperature from 100 to $200^{\circ} \mathrm{C}$ improved $\mathrm{CH}_{3} \mathrm{I}$ capture.

- $\mathrm{Ag}^{\circ} \mathrm{Z}$ was more efficient than $\mathrm{AgZ}$ in capturing $\mathrm{CH}_{3} \mathrm{I}$.

- The presence of water $\left(5 \times 10^{-4}\right.$ vs $4.3 \times 10^{-6}$ mole $\left.\mathrm{H}_{2} \mathrm{O} / \mathrm{L}\right)$ in the gas phase improved $\mathrm{CH}_{3} \mathrm{I}$ capture.

- Dimethyl ether was detected as one of the reaction products in the column effluent.

Work at $\mathrm{ORNL}$ on $\mathrm{CH}_{3} \mathrm{I}$ capture by $\mathrm{Ag}^{\circ} \mathrm{Z}$ has been described by Jubin (1980, 1982). He used $5 \mathrm{~cm}$ dia $\times 10$ to $15 \mathrm{~cm}$ deep beds of $0.16 \mathrm{~cm}$ dia extrudate, a $10 \mathrm{~m} / \mathrm{min}$ face velocity, bed temperatures ranging from 83 to $275^{\circ} \mathrm{C}$, a typical $\mathrm{CH}_{3} \mathrm{I}$ concentration of $7 \times 10^{-6}$ mole $\mathrm{CH}_{3} \mathrm{I} / \mathrm{L}$, and a termination $\mathrm{RF}$ of $10^{3}$. He prepared his own AgZ by ion exchange of $\mathrm{NaZ}$ and also obtained commercially prepared AgZ from Ionex Corporation. He typically generated the $\mathrm{Ag}^{\circ} \mathrm{Z}$ by treatment with $4.5 \% \mathrm{H}_{2}-\mathrm{Ar}$ at $200^{\circ} \mathrm{C}$ for 24 hours.

A summary of Jubin's conclusions regarding $\mathrm{CH}_{3} \mathrm{I}$ capture by $\mathrm{Ag}^{\circ} \mathrm{Z}$ is given below:

- $\mathrm{Ag}^{\circ} \mathrm{Z}$ is a more efficient trap for $\mathrm{CH}_{3} \mathrm{I}$ than $\mathrm{AgZ}$; loadings up to 127 $\mathrm{mg} I / g \mathrm{Ag}^{\circ} \mathrm{Z}$ are possible.

- $\mathrm{CH}_{3} \mathrm{I}$ concentration and the presence of $\mathrm{NO}$ and/or $\mathrm{NO}_{2}$ have no effect.

- Moist air up to $2 \times 10^{-3}$ mole $\mathrm{H}_{2} \mathrm{O} / \mathrm{L}$ improves iodine capture.

- Higher temperatures up to $225^{\circ} \mathrm{C}$ improve loading.

- Higher temperatures increase the length of the mass transfer zone; at $150^{\circ} \mathrm{C}$ it was 5 to $7.5 \mathrm{~cm}$; at $200^{\circ} \mathrm{C}$ it was $>10 \mathrm{~cm}$.

- Higher temperatures $\left(200\right.$ to $500^{\circ} \mathrm{C}$ ) and longer exposure times (24 or 48 hours) for reduction by $100 \% \mathrm{H}_{2}$ increase the size of the metallic silver nodules formed and reduce loading capacity. 
- When using $\mathrm{Ag}^{\circ} \mathrm{Z}$ produced at higher temperatures, higher loadings were reached with glass filter housings than with stainless steel housings.

- Partially exchanged $\mathrm{Ag}^{\circ} \mathrm{Z}$ improved silver utilization. 
.

. 


\section{FACTORS INFLUENCING IODINE SORPTION}

The sorption of elemental iodine or organic iodides by $\mathrm{Ag}^{\circ} \mathrm{Z}$ from the POG is a complex process whose chemistry is poorly understood. Furthermore, this sorption process can be affected by several operational factors, physical characteristics of $\mathrm{Ag}^{\circ} \mathrm{Z}$, and several constituents of the POG. Several of these are discussed below.

\section{ZEOLITE STRUCTURE}

One of the more important factors is the zeolite itself. For this study only silver mordenite made from the synthetic sodium mordenite Zeolon was used; $\mathrm{NaZ}$ is a high silica zeolite of nominal composition $\mathrm{Na}_{2} \mathrm{O} \cdot \mathrm{Al}_{2} \mathrm{O}_{3} \cdot 10$ $\mathrm{SiO}_{2} \cdot 6 \mathrm{H}_{2} \mathrm{O}$ (Breck 1974). Figure 1 presents a stereo view of its structure. There are two sets of channels. The main ones, which are $6.7 \times 7.0 \AA$, i.e. $7 \AA$ in pore size, are linked in the same plane by small pockets having apertures of $3.6 \AA$ (Breck 1974). The effective pore sizes could be changed slightly by substituting $\mathrm{Ag}$ for $\mathrm{Na}$. The pore size limits access to the interior of the $\mathrm{AgZ}$. In order for iodine to be sorbed it must pass through the pore openings, and its ability to enter the pores is limited by its molecular size or kinetic diameter. For example, $I_{2}$ has a kinetic diameter of $5 \AA$ (see Table 1), and we estimate that $\mathrm{CH}_{3} \mathrm{I}$ has a kinetic diameter of $\sim 6 \AA$ [extrapolating Kennard's (1938) value for $\mathrm{CH}_{3} \mathrm{Br}$. For these iodine species, mordenite may be one-dimensional; i.e., the molecule may not be able to enter the small channels.

Although blockage of the main channels is common in natural mordenites as a result of impurities or crystal faults, it does not appear to be a problem with the synthetic material Zeolon ${ }^{\otimes}$ Of the eight $\mathrm{Na}$ atoms of the unit cell, four are in small cavities and four randomly situated in the large channels. Al1 are apparently replaceable with $\mathrm{Ag}$ ions; however, they are obviously not equally accessible. We discuss other considerations for using $\mathrm{AgZ}$ and $\mathrm{Ag}^{\circ} \mathrm{Z}$ in a document on the recycling of $\mathrm{AgZ}$ by hydrogen reduction (Burger and Scheele 1982).

- Trademark of the Norton Company. 


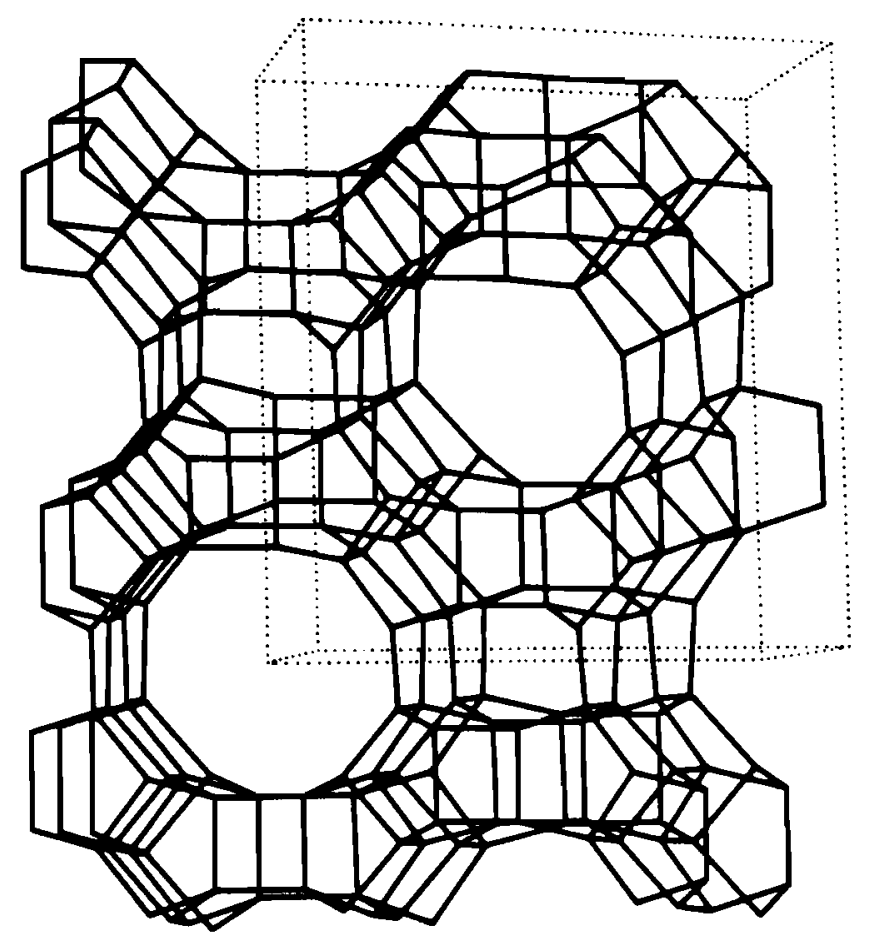

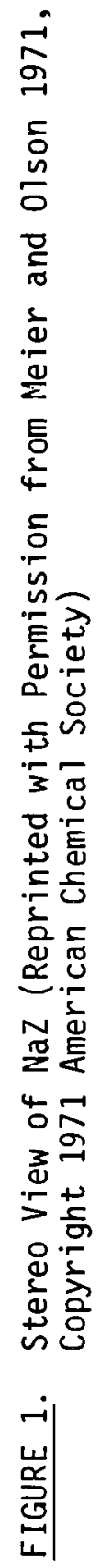

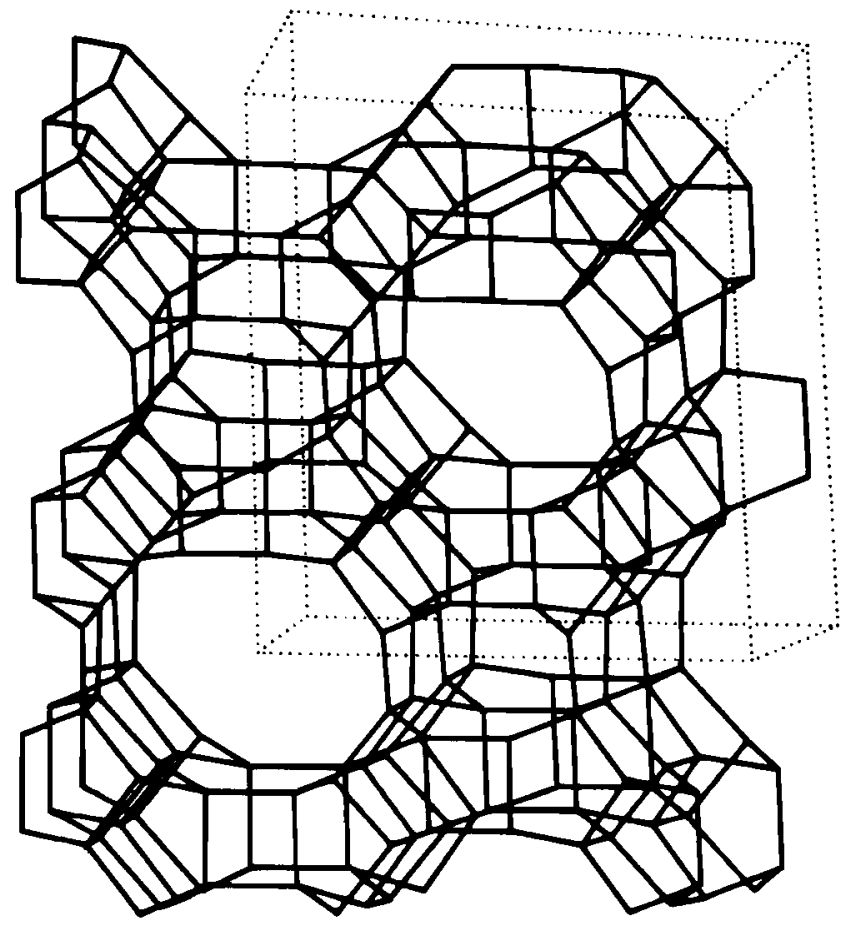


TABLE 1. Critical Diameters for Some Molecules of Interest Critical Diameter, $\AA$

\begin{tabular}{|c|c|c|c|c|c|}
\hline Molecule & Breck (a) & $\begin{array}{l}\text { Hirsch- } \\
\text { felder }(b)\end{array}$ & $\begin{array}{l}\text { Glasstone }(c) \\
\text { (Diffusion) }\end{array}$ & $\begin{array}{l}\text { Glasstone }(c) \\
\text { (Viscosity) }\end{array}$ & Kennard (d) \\
\hline $\mathrm{Ar}$ & 3.40 & 3.42 & & & \\
\hline $\mathrm{H}_{2} \mathrm{O}$ & 2.65 & & & & 4.60 \\
\hline $\mathrm{CO}_{2}$ & 3.3 & 3.9 & 4.38 & 4.60 & 4.59 \\
\hline $\mathrm{O}_{2}$ & 3.46 & 3.5 & 3.64 & 3.61 & 3.61 \\
\hline $\mathrm{N}_{2}$ & 3.64 & 3.7 & 3.84 & 3.75 & 3.75 \\
\hline NO & 3.17 & 3.5 & & & \\
\hline $\mathrm{N}_{2} \mathrm{O}$ & 3.3 & 3.8 & & & \\
\hline $\mathrm{Cl}_{2}$ & 3.2 & 4.1 & & & \\
\hline $\mathrm{Br}_{2}$ & 3.5 & 4.3 & & & \\
\hline $\mathrm{I}_{2}$ & & 5.0 & 4.6 & & \\
\hline $\mathrm{HCl}$ & & & 2.86 & & 4.46 \\
\hline $\mathrm{HBr}$ & & & 3.16 & & \\
\hline $\mathrm{HI}$ & & 4.1 & 3.50 & & \\
\hline $\mathrm{CH}_{4}$ & & 3.8 & 3.2 & & 4.14 \\
\hline $\mathrm{CH}_{3} \mathrm{OH}$ & & 3.6 & & & \\
\hline $\mathrm{CH}_{3} \mathrm{Cl}$ & & 3.4 & & & \\
\hline $\mathrm{CH}_{3} \mathrm{Br}$ & & & & & 5.85 \\
\hline $\mathrm{H}_{2}$ & 2.89 & & 2.72 & 2.74 & 2.74 \\
\hline
\end{tabular}

\footnotetext{
(a) Breck (1974).

(b) Hirschfelder, Curtiss, and Bird (1954).

(c) Glasstone and Bell (1946).

(d) Kennard (1938).
}

\section{MOLECULAR SIEVE EFFECTS}

One of the major industrial uses of zeolites is as a molecular sieve. Different gaseous molecules introduced into a column of zeolite will behave differently within the bed due to their size. Some will pass easily through the pore opening and others will not. The latter molecules will leave the bed first. Table 1 presents some critical diameters for several molecules, some 
present in our system. Of the major constituents, the largest molecules of interest are $\mathrm{I}_{2}$ and $\mathrm{CH}_{3} \mathrm{I}$; there may also be small concentrations of higher organic iodides. The other molecules in our system such as the components of air $\left(\mathrm{N}_{2}, \mathrm{O}_{2}, \mathrm{Ar}, \mathrm{CO}_{2}\right.$, and $\left.\mathrm{H}_{2} \mathrm{O}\right)$ are all smaller than the large aperture, and several are smaller than the small aperture. Ignoring electrostatic effects or chemical reactions, their size allows them to enter and leave at will. This is also true for $\mathrm{NO}$ and probably $\mathrm{NO}_{2}$, both of which are present in the POG. I 2 and $\mathrm{CH}_{3} \mathrm{I}$ will be only slightly hindered in entering and leaving the large pores. It appears that sieving effects of the zeolite will be by the small pores.

Thus all of the molecules in the POG will be free to enter the large pores and potentially be adsorbed or react with the silver within the large pores. Access to the silver in the small pores will be limited to the smaller molecules such as $0_{2}$ and NO. Adsorption or the presence of different compounds within the pores could reduce the ability of $\mathrm{Ag}^{\circ} \mathrm{Z}$ or $\mathrm{AgZ}$ to sorb iodine species by limiting their access into the pore and to the reactive silver sites. The adsorption of water, however, could enhance iodine sorption by mobilizing silver ions in a micro-solution within the zeolite's pores; this effect should be most influential in the ionic form, AgZ. Water may, of course, take part in the chemical reactions.

HYDROGEN PRETREATMENT OF AgZ

It should be mentioned that particles of silver are scattered throughout the $\mathrm{Ag}^{\circ} \mathrm{Z}$. (See Figure 2, which is a scanning electron micrograph of iodineloaded $\mathrm{Ag}^{\circ} \mathrm{Z}$.) During reduction, the silver migrates from the pores and agglomerates, forming particles up to 2 um dia (Coleman and Scheele 1981; Danie1, Coleman, and Scheele 1980). Thus, much of the silver is not contained within the zeolite pores. The extent of silver migration and the size of these agglomerates will depend on a number of factors, including water content at the time of reduction, and the temperature and time for reduction (Minachev and Isakov 1976). Our studies indicate that the $I_{2}$ is preferentially absorbed in these Ag particles rather than in the zeolite matrix. Therefore, the silver 


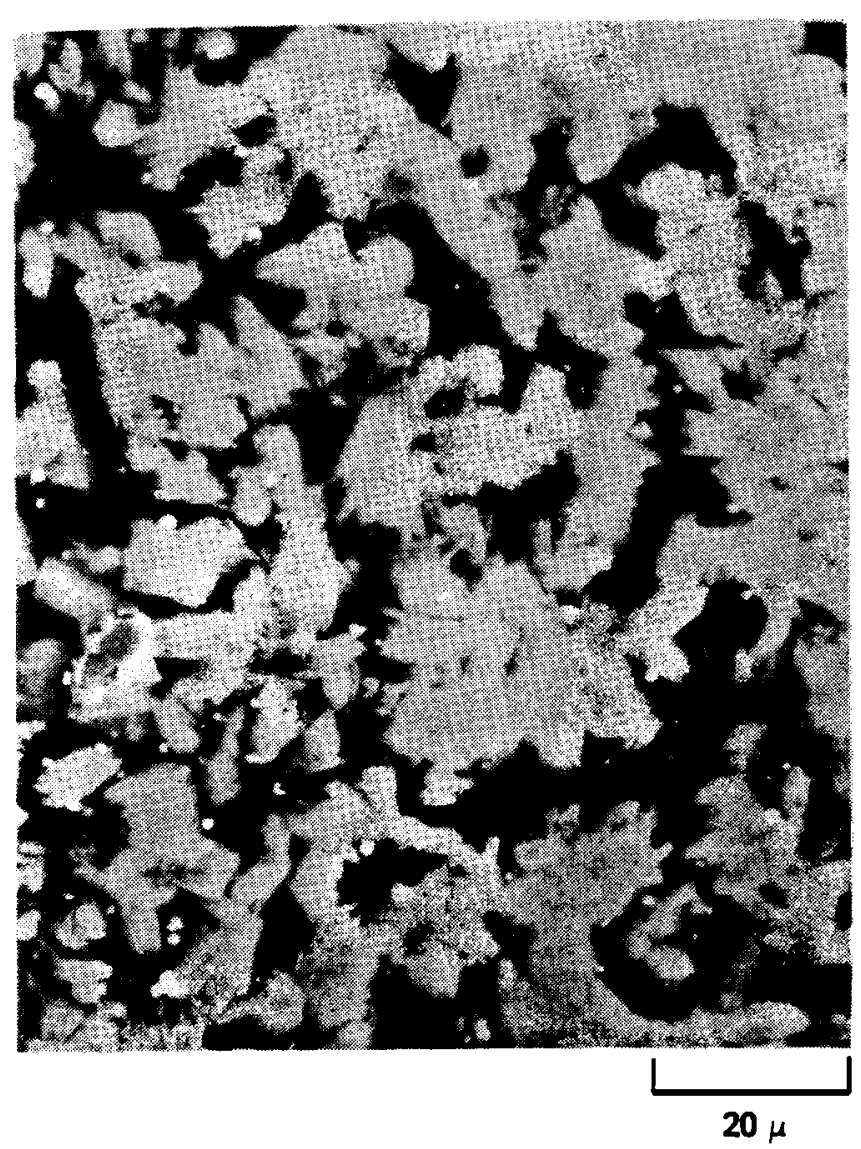

FIGURE 2. Scanning Electron Micrograph of Iodine-Loaded $\mathrm{Ag}^{\circ} \mathrm{Z}$

should be more accessible to the $\mathrm{I}_{2}$ in $\mathrm{Ag}^{\circ} \mathrm{Z}$ than in $\mathrm{AgZ}$, provided that the $\mathrm{Ag}$ particles are not too big.

Jubin's (1982) work indicates that the hydrogen reduction conditions and exposure time used for preparing $\mathrm{Ag}^{\circ} \mathrm{Z}$ affect the ability of $\mathrm{Ag}^{\circ} \mathrm{Z}$ to capture $\mathrm{CH}_{3} \mathrm{I}$. The longer the hydrogen pretreatment and the higher the temperature, the poorer the $\mathrm{CH}_{3} \mathrm{I}$ sorption. Jubin attributes this to the larger particle size of $\mathrm{Ag}$ metal formed at the more extreme conditions. In other work (Burger and Scheele 1982), we found erratic trapping behavior for $\mathrm{I}_{2}$ during repeated loading and hydrogen reduction cycles. 
CHEMICAL FACTORS

In addition to the factors just discussed, a large number of competing chemical reactions can occur among the reactive components in the zeolite and in the POG which could affect $\mathrm{I}_{2}$ retention by $\mathrm{AgZ}$ or $\mathrm{Ag}^{\circ} \mathrm{Z}$.

Iodine Sorption (Previous Studies)

Donner and Tamberg $(1971,1972)$ studied the reaction between $\mathrm{CH}_{3} \mathrm{I}$ and silver zeolite type $X(A g X)$ and found that methanol and dimethyl ether were formed. The following reactions were proposed:

$$
\begin{aligned}
& \mathrm{CH}_{3} \mathrm{I}+\mathrm{H}_{2} \mathrm{O}+\mathrm{Ag}^{+}+\mathrm{AgI}+\mathrm{CH}_{3} \mathrm{OH}+\mathrm{H}^{+} \\
& \mathrm{CH}_{3} \mathrm{I}+\mathrm{CH}_{3} \mathrm{OH}+\mathrm{Ag}^{+}+\mathrm{AgI}+\mathrm{CH}_{3} \mathrm{OCH}_{3}+\mathrm{H}^{+}
\end{aligned}
$$

In their earlier paper they also report that when $\mathrm{C}_{2} \mathrm{H}_{5} \mathrm{I}$ is sorbed by $\mathrm{AgX}$, diethyl ether forms, suggesting a similar sorption mechanism with ethanol as an intermediate.

We performed some preliminary work on the chemistry of $\mathrm{I}_{2}$ and $\mathrm{CH}_{3} \mathrm{I}$ sorption by silver containing sorbents. Differential scanning calorimetry (DSC), thermogravimetric analysis (TGA), scanning electron microscopy (SEM) coupled with $x$-ray fluorescence elemental analysis, and ESCA-Auger spectroscopy were used to characterize iodine sorption reactions and their products and/or to determine the stability of $\mathrm{I}_{2}$ on the silver sorbents. The results of these studies were discussed in Burger and Scheele (1981) and Scheele and Burger (1981).

NO Behavior on Zeolites

Since $\mathrm{NO}$ and $\mathrm{NO}_{2}$ are reactive species, their behavior when adsorbed by zeolites could significantly affect how well iodine is sorbed. Breck (1974) referenced several works on $\mathrm{NO}$ or $\mathrm{NO}_{2}$ adsorption by zeolites. These are discussed in the following.

Addison and Barrer (1955) reported that NO disproportionates upon adsorption in $\mathrm{Ca}$ - and $\mathrm{Na}-\mathrm{rich}$ forms of chabazite, faujasite, mordenite, and a synthetic zeolite with mordenite-like molecular sieve properties. Chao and 
Lumsford (1971a, 1971b) found also that NO, upon adsorption by zeolite Y, disproportionates. They reported the following disproportionation reaction:

$$
4 \mathrm{NO}+\mathrm{N}_{2} \mathrm{O}+\mathrm{N}_{2} \mathrm{O}_{3}
$$

Studying $\mathrm{CaY}, \mathrm{NaY}, \mathrm{HY}$, and decationized $\mathrm{Y}$ zeolites at room temperature, Chao and Lumsford identified the adsorbed species $\mathrm{N}_{2} \mathrm{O}, \mathrm{NO}_{2}{ }^{+}, \mathrm{N}_{2} \mathrm{O}_{3}, \mathrm{NO}_{3}{ }^{-}$, a nitrito complex, and nitrite. The final products were $\mathrm{N}_{2} \mathrm{O}$ and $\mathrm{NO}_{2} \cdot$ At low temperatures $\mathrm{N}_{2} \mathrm{O}_{2}$, NO, and disproportionation products were found.

Kasai and Bishop (1972) used electron spin resonance (ESR) spectroscopy to study $\mathrm{NO}$ adsorption on $\mathrm{NaY}, \mathrm{BaY}$, and $\mathrm{ZnY}$ and found that the initial spectra were broad and poorly defined, but after the samples had stood for several days, the spectra became sharp and well defined. They concluded that $\mathrm{N}_{2} \mathrm{O}_{3}$ was initially formed by disproportionation, but it ionized due to the internal field of the zeolite.

Pietzak and Wood (1970) found $\mathrm{NO}_{2}$ adsorbed in calcium zeolite type $X$ (CaX) exhibited hindered motion. Adsorbed $\mathrm{N}_{2}$ molecules (about 11 per cavity) are essentially dimerized. The single $\mathrm{NO}_{2}$ molecule surrounded by several $\mathrm{N}_{2} \mathrm{O}_{4}$ molecules is shielded from interacting with surface cations.

Thermodynamic Considerations

Several potential reactions and their free energies are presented in Table 2. The first set of reactions (1 through 16) are potential iodine absorption reactions. The next set (17 through 22 ) are reactions between oxides of nitrogen and metallic silver which would compete with iodine sorption; note that $\mathrm{NO}$ in reaction 17 could reduce $\mathrm{Ag}_{2} \mathrm{O}$, which may be present in partially reduced $\mathrm{Ag}^{\circ} \mathrm{Z}$. However, the subsequent reactions in the table suggest oxidation to $\mathrm{Ag}_{2} \mathrm{O}$ or $\mathrm{Ag}^{+}$as predominant. The third set (23 through 30 ) are reactions between $\mathrm{AgI}$, the optimum silver-iodine species for retention, and the oxides of nitrogen. Included are reactions with such species as $\mathrm{N}_{2} \mathrm{O}_{3}$ and $\mathrm{N}_{2} \mathrm{O}_{4}$, which may be adsorption products of $\mathrm{NO}$ and $\mathrm{NO}_{2}$.

Many reactions in set $I$ are thermodynamically favorable for $\mathrm{I}_{2}$ or $\mathrm{CH}_{3} \mathrm{I}$ capture by $\mathrm{Ag}^{\circ} \mathrm{Z}$ or $\mathrm{AgZ}$. The iodine species produced are $\mathrm{AgI}$ or $\mathrm{AgIO}_{3}$. In 
TABLE 2. Reaction Free Energies for Some Possible Reactions in $\mathrm{Ag}^{\circ} \mathrm{Z}$

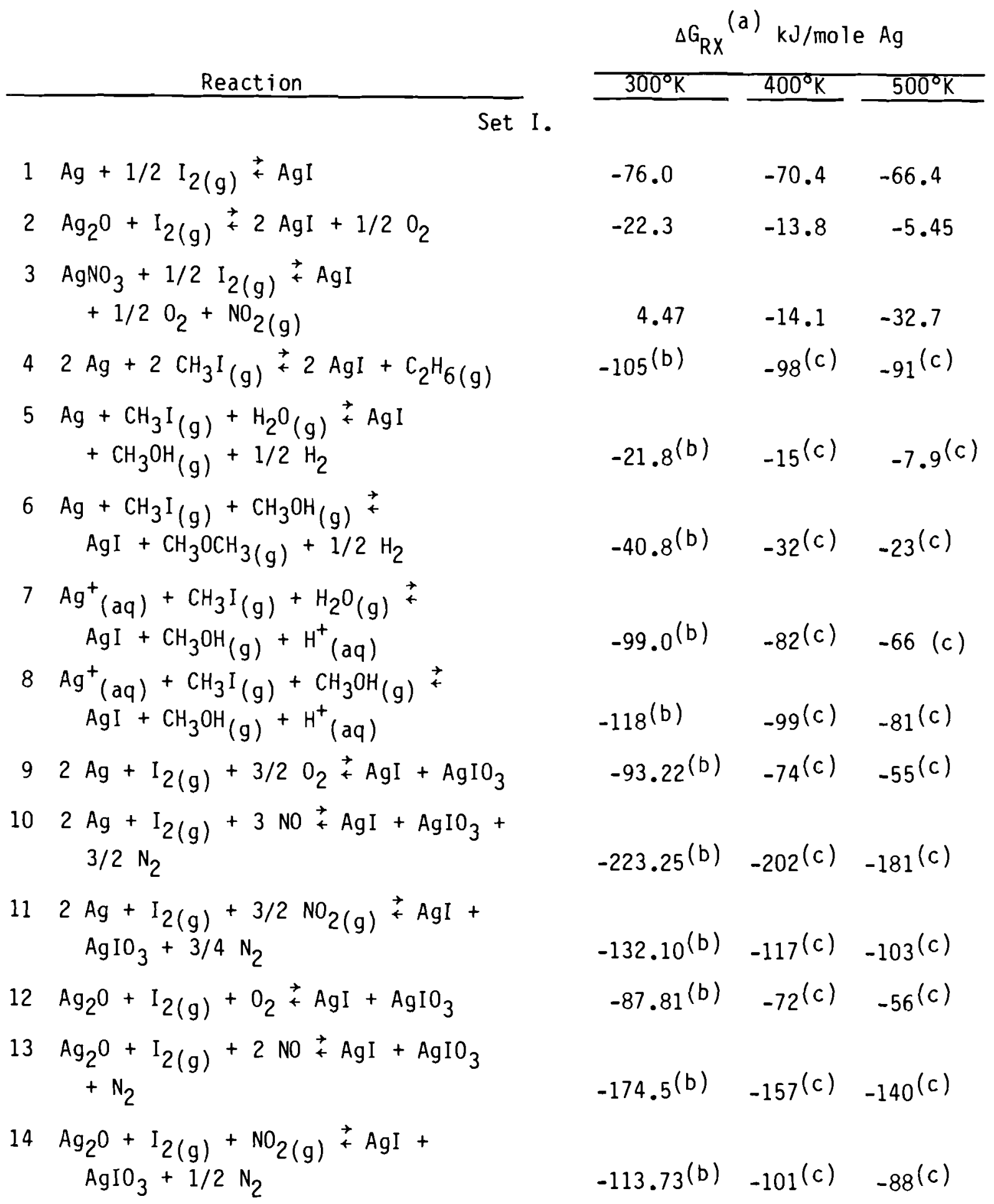


TABLE 2. (contd)

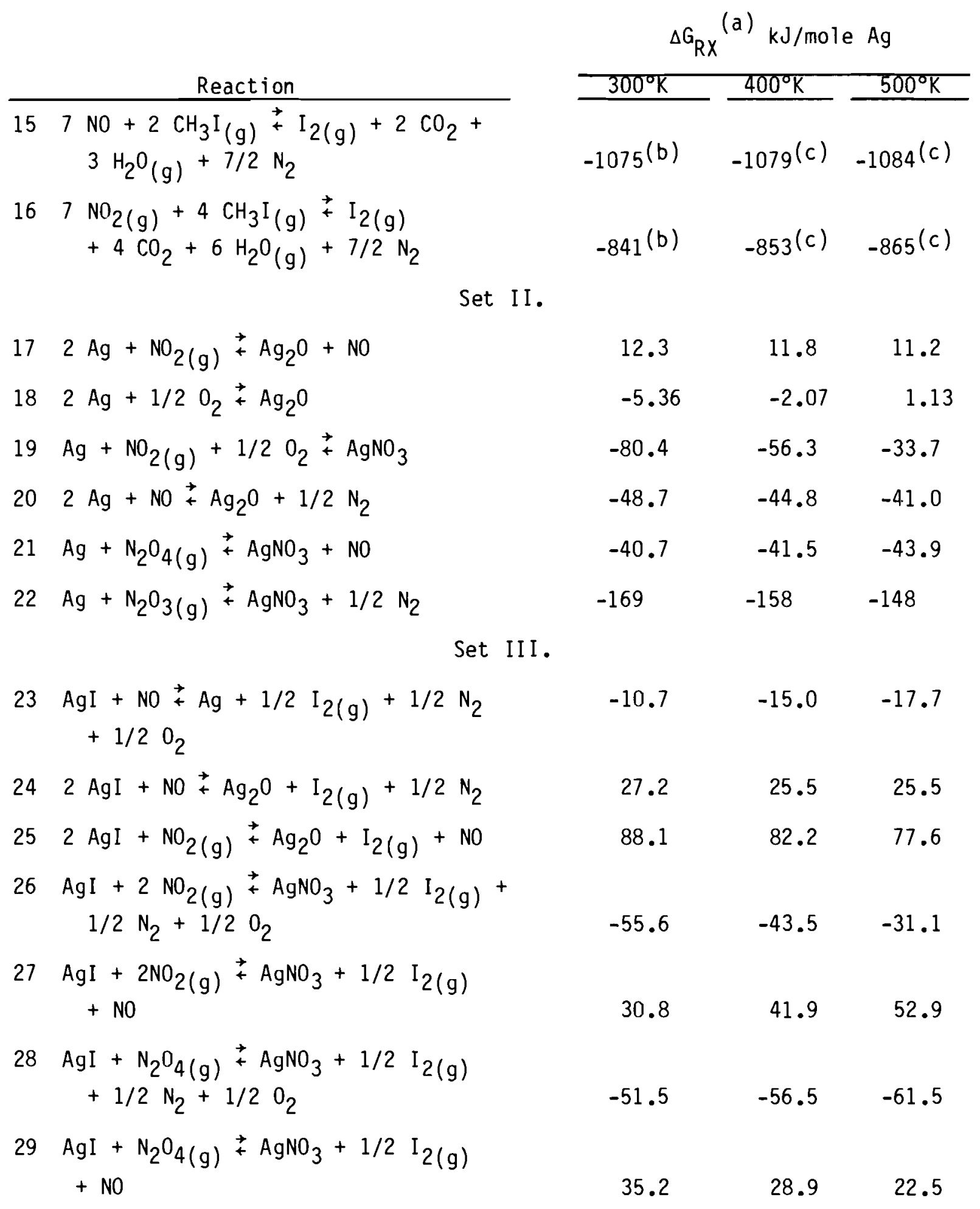


TABLE 2. (contd)

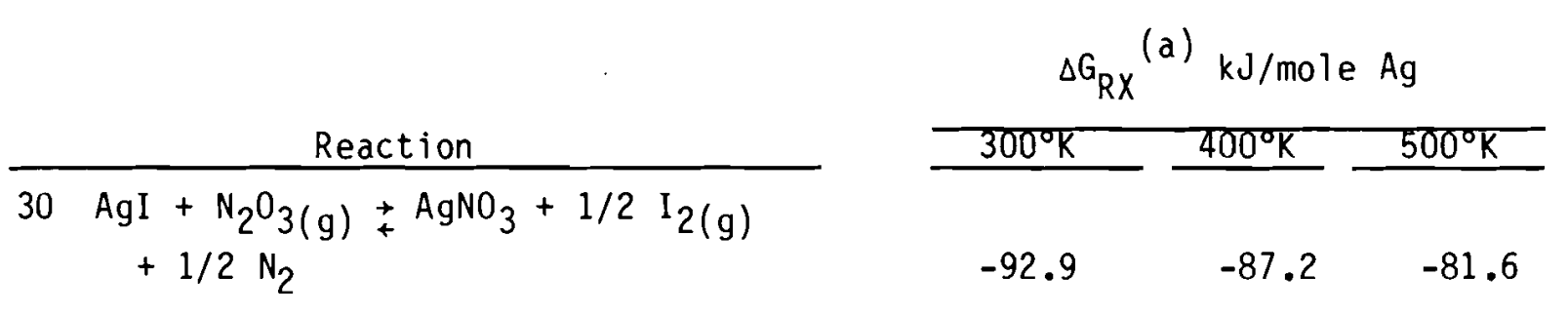

(a) Calculated based on data from Barin and Knacke (1973) or Barin, Knacke, and Kubaschewski (1977), except as noted.

(b) Calculated based on data for $298^{\circ} \mathrm{K}$ from Latimer (1956).

(c) Calculated using equation $\Delta G=\Delta H+A T$.

other work (Burger and Scheele 1981), sorbed $I_{2}$ was released at temperatures lower than the decomposition or volatilization temperatures of either compound, suggesting the presence of a silver-iodine complex.

The first set of reactions show that $\mathrm{NO}$ and $\mathrm{NO}_{2}$ enhance the $\mathrm{I}_{2}$ capture process, but in the second section the general impact of $\mathrm{NO}$ or $\mathrm{NO}_{2}$ is detrimental. It is obvious that the presence of $\mathrm{NO}_{x}$ greatly complicates zeolite chemistry. In the second section we find that $\mathrm{NO}_{2}$ endothermically oxidizes $\mathrm{Ag}$ to $\mathrm{Ag}_{2} \mathrm{O}$, which has a less energetically favored reaction with $\mathrm{I}_{2}$; however, if NO is also present in the gas stream, this oxidation will not occur. Murphy, Staples, and Thomas (1977) attributed the positive effect of NO and the negative effect of $\mathrm{NO}_{2}$ on $\mathrm{I}_{2}$ capture to this reaction. However, in another case, No will exothermically oxidize $\mathrm{Ag}$ to $\mathrm{Ag}_{2} \mathrm{O}$ (reaction 20). The remaining reactions in the second set of reactions are all exothermic and should all compete with iodine sorption reactions; note that the silver products will also react with $\mathrm{I}_{2}$.

In the third set of reactions, there are several which favor release of $I_{2}$ from AgI. Again, the oxides of nitrogen tend to destabilize iodine retention. Two reactions presented in Table 1 show oxidation of $\mathrm{CH}_{3} \mathrm{I}$ by $\mathrm{NO}$ and $\mathrm{NO}_{2}$ to form $\mathrm{I}_{2}$. Both reactions are strongly exothermic and should improve trapping efficiency, since $\mathrm{I}_{2}$ is more easily trapped than $\mathrm{CH}_{3} \mathrm{I}$. 
Not considered in this analysis is the presence of other halogen species such as $\mathrm{Cl}_{2}$ or $\mathrm{Br}_{2}$, which could displace trapped iodine. Strachan (1978) analyzed some old iodine absorbers (silver reactors) from the Hanford Purex Plant and found that they were loaded principally with $\mathrm{Cl}$.

OPERATIONAL PARAMETERS

Other factors affecting iodine sorption are operational parameters of the $\mathrm{Ag}^{\circ} \mathrm{Z}$ bed. These include $\mathrm{Ag}^{\circ} \mathrm{Z}$ particle size, temperature, and four factors which are closely interrelated: face velocity, bed diameter, bed length, and residence time.

A smaller particle size $\mathrm{Ag}^{\circ} \mathrm{Z}$ would be expected to be more efficient because of both increased surface area and a smaller diffusion path. The free volume does not change appreciably, nor does gas flow; i.e., the flow is expected to be laminar for the particle sizes and flows used here. This was verified by measurement of flow-pressure drop.

The effect of temperature will depend on what the controlling reactions are: they may be physical, e.g., diffusion and/or adsorption and have a relatively low activation energy, $E_{a}$; or chemical, with much higher $E_{a}$ values. In any case, we would expect them to be linear with respect to $\exp (-1 / T)$.

Bed diameter and length are interrelated with face velocity and residence time. In this study, we ignored the potential effects of bed sizing and residence time and arbitrarily selected a bed diameter and a length to exceed the expected mass tranfer zone, thus lumping these factors into one variable, superficial face velocity. Face velocity would be expected to have a linear effect if there is no change in mechanism.

The factors selected for study were presence of $\mathrm{NO}$, presence of $\mathrm{NO}_{2}$, temperature, and superficial face velocity. The experimental program was selected to determine which factors affected $\mathrm{CH}_{3} \mathrm{I}$ sorption. 

EXPERIMENTAL CONSIDERATIONS

We performed two sets of experiments, the first using a $2.5 \mathrm{~cm} \mathrm{dia} \times 15 \mathrm{~cm}$ deep bed, and the second using a $5.0 \mathrm{~cm}$ dia $\times 18.0 \mathrm{~cm}$ deep bed. The basic system is diagrammed in Figure 3 . The operating conditions for each experiment are presented in Table 3 and Table 4, respectively. The containers for the mordenite and other glass components in the system were borosilicate glass. Other materials used in construction were stainless steel and plastic tubing. The plastic (Teflon and Tygon ${ }^{\circledR}$ ) tubing was restricted to locations upstream from the heaters.

To insure constant temperature throughout the bed, three heat tapes were used, and the bed insulated with a ceramic fiber blanket. Thermocouples were placed in each bed segment. Initially, we used proportional temperature controllers. Later, a small laboratory computer monitored and controlled bed segment temperatures. In addition to temperature monitoring and control, the computer also initiated experiments and monitored and recorded other experimental conditions such as flow rates and dew point.

We pretreated each bed with air for 16 hours at the operating temperature. This insured an equilibrium water content and silver oxidation state.

Gas tanks containing $\sim 4 \times 10^{-4}$ mole $\mathrm{CH}_{3} \mathrm{I} / \mathrm{L} \mathrm{N} \mathrm{N}_{2}$ were prepared and used as the $\mathrm{CH}_{3} \mathrm{I}$ source. The influent $\mathrm{CH}_{3} \mathrm{I}$ concentration used in our experiments was $1.3 \times 10^{-5}$ moles $\mathrm{CH}_{3} \mathrm{I} / \mathrm{L}$. The $\mathrm{CH}_{3} \mathrm{I}$ concentration varied with each individual tank so it was necessary to adjust flows based on standard analyses made prior to each run.

$\mathrm{NO}_{2}$ was prepared by reacting 1 part $\mathrm{NO}$ with 9 parts $\mathrm{O}_{2}$ in a $1 \mathrm{~L}$ or $3 \mathrm{~L}$ holdup flask. For the experiments with NO experiments, the NO conversion to $\mathrm{NO}_{2}$ by reaction with air was minimized by introducing the NO just prior to the top of the mordenite bed.

Teflon is a trademark of E. I. du Pont de Nemours \& Co.

(B) Tygon is a trademark of the Norton Company. 


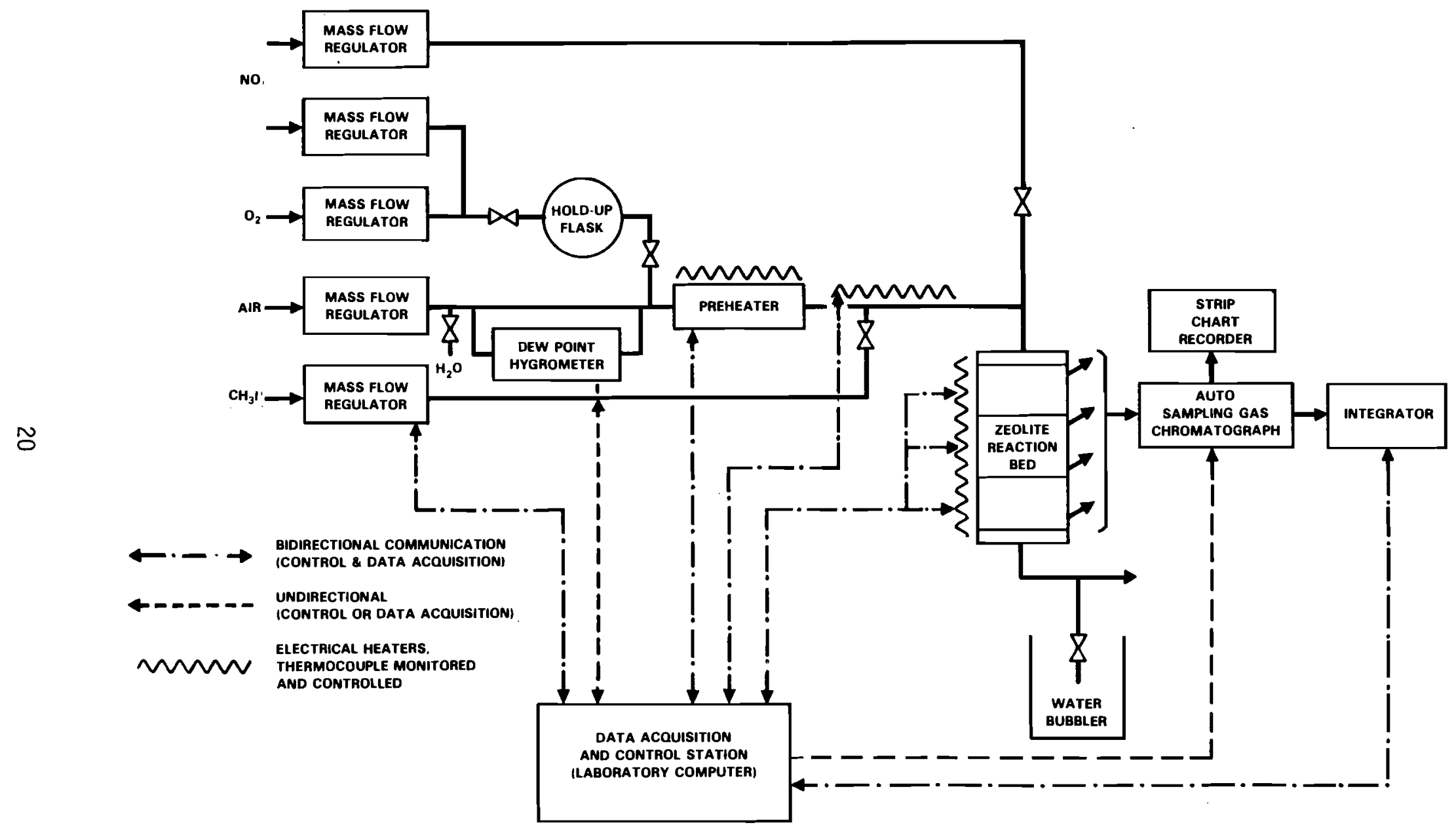

FIGURE 3. Experimental Apparatus for $\mathrm{CH}_{3} \mathrm{I}$ Capture by Silver Mordenite ( $\mathrm{AgZ}$ or $\mathrm{Ag}^{\circ} \mathrm{Z}$ ) 
TABLE 3. Operating Parameters for $2.5 \mathrm{~cm} \mathrm{Dia} \mathrm{Bed}$

\begin{tabular}{|c|c|}
\hline Bed length, cm & 15 \\
\hline Bed diameter, $\mathrm{cm}$ & 2.54 \\
\hline Bed material & $\mathrm{AgZ}$ or $\mathrm{Ag}^{\circ} \mathrm{Z}$ \\
\hline Particle size & $\begin{array}{l}20-40 \text { mesh or } \\
\text { diameter ext }\end{array}$ \\
\hline Bed temperature, ${ }^{\circ} \mathrm{C}$ & 110,150 , or \\
\hline Face velocity, $\mathrm{m} / \mathrm{min}$ & 7.5 \\
\hline Carrier gas & Air \\
\hline $\begin{array}{l}\mathrm{CH}_{3} \mathrm{I} \text { concentration, mole/L } \\
\mathrm{H}_{2} \mathrm{O} \text { concentration, mole/L }\end{array}$ & $1.3 \times 10^{-5}$ \\
\hline Laboratory air & $\sim 5 \times 10^{-4}$ \\
\hline Tank air & $4 \times 10^{-6}$ \\
\hline NO concentration, mole/L & 0 or $8 \times 10^{-4}$ \\
\hline $\mathrm{NO}_{2}$ concentration, mole/L & 0 or $8 \times 10^{-4}$ \\
\hline
\end{tabular}

TABLE 4. Operating Parameters for $5.0 \mathrm{~cm}$ Dia Bed

\begin{tabular}{|c|c|}
\hline Bed length, cm & 18 \\
\hline Bed diameter, cm & 5.08 \\
\hline Bed material & $\mathrm{Ag}^{\circ} \mathrm{Z}$ \\
\hline Particle size & $10-16$ mesh \\
\hline Bed temperature, ${ }^{\circ} \mathrm{C}$ & $86,116,152$, or 200 \\
\hline Face velocity, $\mathrm{m} / \mathrm{min}$ & $3.75,7.5$, or 15 \\
\hline Carrier gas & Air \\
\hline $\mathrm{CH}_{3} \mathrm{I}$ concentration, mole/L & $1.3 \times 10^{-5}$ \\
\hline $\mathrm{H}_{2} \mathrm{O}$ concentration, mole/L & $\sim 5 \times 10^{-4}$ \\
\hline NO concentration, mole/L & ${ }_{4 \times 10^{-4}}^{5.2} \times 10^{-5}$ or \\
\hline $\mathrm{NO}_{2}$ concentration, mole/L & $0,2.6 \times 10^{-5}$ or \\
\hline
\end{tabular}


We used laboratory air with a nominal water content of $\sim 5 \times 10^{-4}$ mole $\mathrm{H}_{2} \mathrm{O} / \mathrm{L}$ as our air source. In a few early experiments, we used tank air having a water content of $4 \times 10^{-6}$ mole $\mathrm{H}_{2} \mathrm{O} / \mathrm{L}$. The laboratory air was pumped using an oilfree pump. In preliminary tests with the $5 \mathrm{~cm}$ dia bed, we used an oil lubricated pump. However, oil was observed in the delivery lines. Since this could contaminate the mordenite bed, we switched to completely oil-free components.

The AgZ was procured from Ionex Corporation presized. The AgZ used in the $2.5 \mathrm{~cm}$ dia bed was 20-40 mesh and $0.16 \mathrm{~cm}$ dia extrudate, while in the $5.0 \mathrm{~cm}$ dia bed we used 10-16 mesh (one experiment used 20-40 mesh). The $\mathrm{Ag}^{\circ} \mathrm{Z}$ was prepared by heating the $\mathrm{AgZ}$ at $300^{\circ} \mathrm{C}$ in a dry $\mathrm{N}_{2}$ stream for 3 to 4 hours followed by heating at $500^{\circ} \mathrm{C}$ in flowing $\mathrm{H}_{2}$ for 24 hours.

A gas chromatograph with an auto-sampling valve measured the $\mathrm{CH}_{3} \mathrm{I}$ concentration in the influent and bed segment effluents (see figure 3). For the $2.5 \mathrm{~cm}$ dia bed, samples were taken of the influent and after each $5.0 \mathrm{~cm} \mathrm{seg-}$ ment. For the $5.0 \mathrm{~cm}$ diameter bed, samples were taken of the influent, after the first $8.0 \mathrm{~cm}$, and then after each of the remaining two $5 \mathrm{~cm}$ bed segments. We used a $2 \mathrm{~m}$ Pora-Pak QS ${ }^{\otimes} 80 \times 100$ mesh column at $200^{\circ} \mathrm{C}$ with a he flow of $100 \mathrm{~mL} / \mathrm{min}$. This gave a $\mathrm{CH}_{3} \mathrm{I}$ retention time of 7.5 minutes. A photoionization detector with a $10.5 \mathrm{eV}$ lamp was used. A normal sampling cycle for the entire bed required 50 minutes. Methy 1 iodide standards were run prior to and after each experiment.

When $\mathrm{NO}$ or $\mathrm{NO}_{2}$ was present, some or all of the $\mathrm{CH}_{3} \mathrm{I}$ was converted to $\mathrm{I}_{2}$. We monitored $I_{2}$ progress through the bed using tissue paper dipped in a starch solution. When $I_{2}$ was present, the paper turned the characteristic bluepurple color of the starch-iodine complex. This method allowed us to detect an RF of $\sim 100$.

We used the integrated input $\mathrm{CH}_{3} \mathrm{I}$ to calculate the average bed loading. For selected experiments, each bed segment was analyzed by F. T. Hara and A. W. Lautensleger of PNL using $x$-ray fluorescence to determine the iodine loadings.

Drademark of Waters Associates, Inc. 
Species other than $\mathrm{NO}, \mathrm{NO}_{2}$ or $\mathrm{CH}_{3} \mathrm{I}$ were detected in the off gas. While determination of other chemical species was beyond the scope of this project, possibilities are dimethyl ether or methanol, as mentioned earlier. 


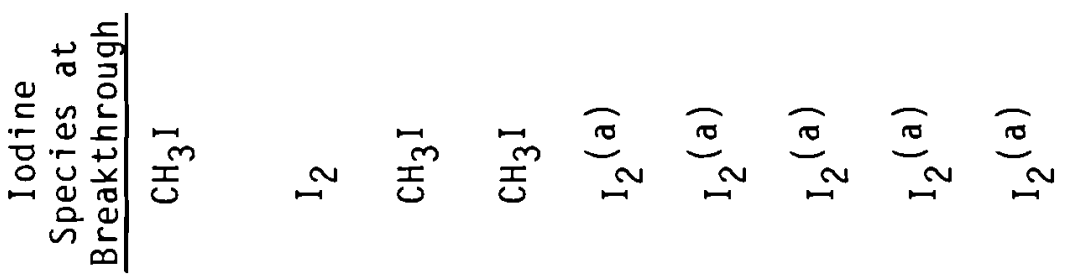

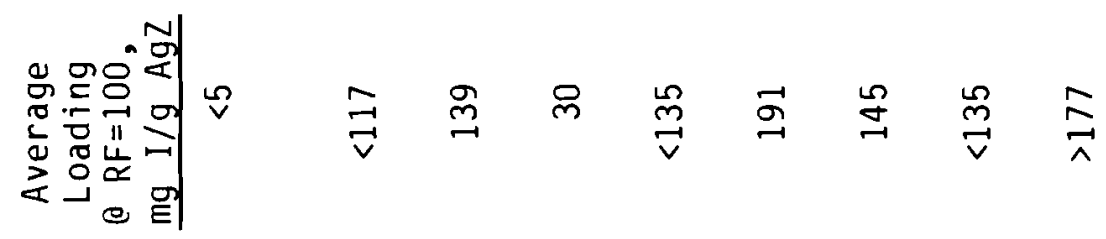

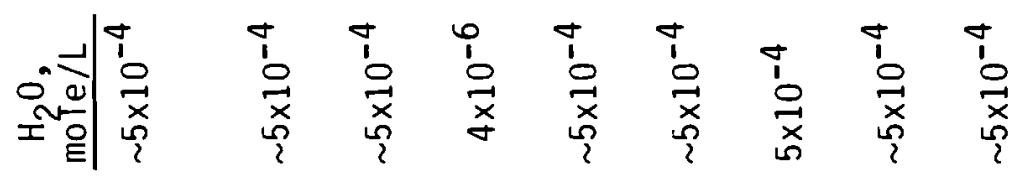

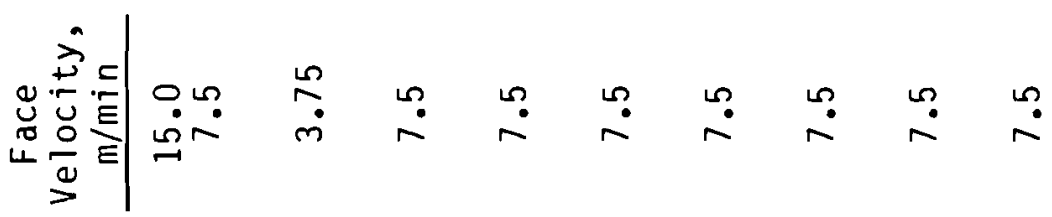

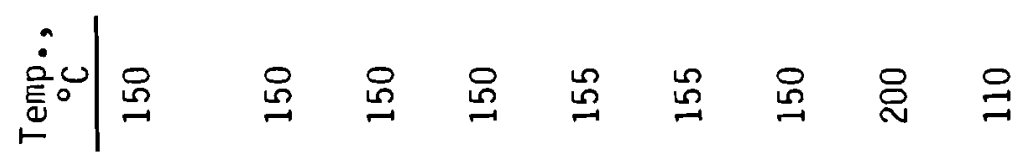

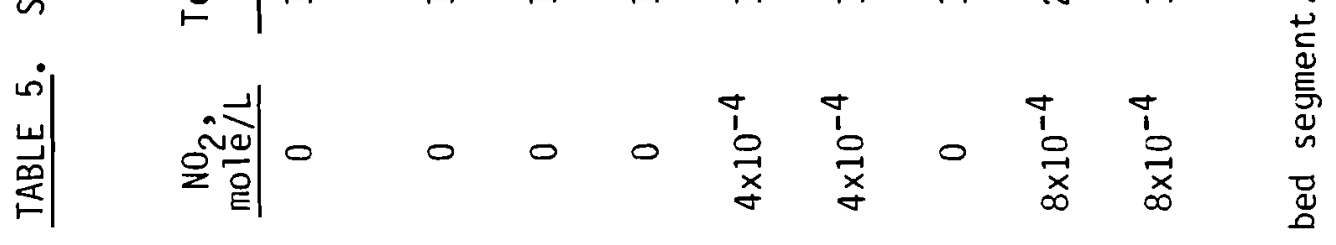

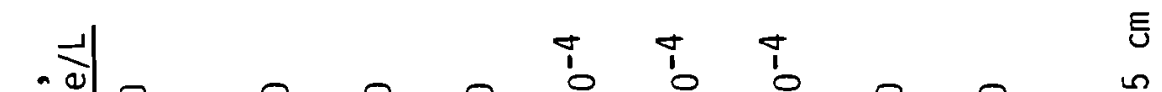

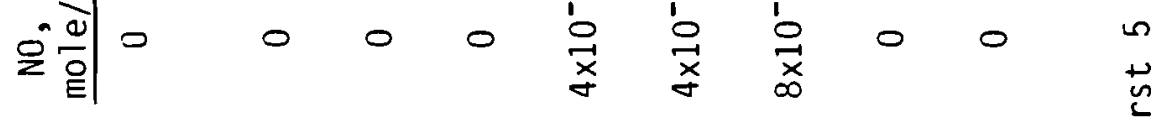

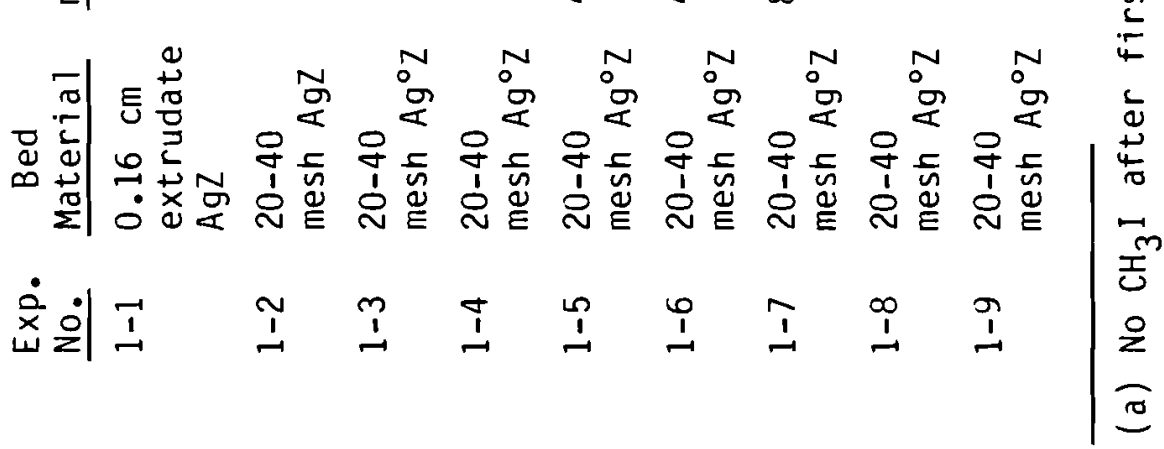




\section{EXPERIMENTAL RESULTS}

Initial plans were to use a $2.54 \mathrm{~cm}$ dia $\times 15 \mathrm{~cm}$ deep bed of 20-40 mesh $\mathrm{Ag}^{\circ} \mathrm{Z}$ to evaluate the effects of temperature, $\mathrm{NO}$, and $\mathrm{NO}_{2}$ on $\mathrm{CH}_{3} \mathrm{I}$ capture using a statistical experimental design $\left(2^{3}\right.$ factorial). After some preliminary work (experiments 1-1 through 1-6) and the first three runs of the experimental design (1-7 through 1-9), it was determined that a larger bed and larger mesh size would give more significant results for process design. We increased the bed size to $5.0 \mathrm{~cm}$ dia $\times 18 \mathrm{~cm}$ deep and the particle size to 10-16 mesh. Based on our work with the $2.5 \mathrm{~cm}$ dia bed, we expanded this experimental design to include a fourth variable, superficial bed velocity. Four experiments (2-1 through 2-4) were performed to measure variability before beginning the statistically designed experimental program (experiments 2-6 through 2-28).

\section{$2.5 \mathrm{~cm}$ DIA BED STUDY}

The experimental parameters and results for the small bed are presented in Table 5. Appendix Figures $\mathrm{A} .1$ and $\mathrm{A} .2$ present $\mathrm{CH}_{3} \mathrm{I}$ concentration in the influent and effluents for each $5 \mathrm{~cm}$ bed segment as a function of average bed loading for experiments $1-3$ and 1-4.

For the other experiments, measurement of $\mathrm{CH}_{3} \mathrm{I}$ concentrations was impossible because $\mathrm{CH}_{3} \mathrm{I}$ was converted to $\mathrm{I}_{2}$ in the first bed segment. In comparing these and subsequent data, it may be noted that the maximum theoretical loading, assuming $\mathrm{AgI}$, is about $225 \mathrm{mg} \mathrm{I} / \mathrm{g}$ zeolite.

From these preliminary studies, several observations can be made:

- If $\mathrm{NO}$ or $\mathrm{NO}_{2}$ was present, the $\mathrm{CH}_{3} \mathrm{I}$ was converted to $\mathrm{I}_{2}$ for $\mathrm{Ag}^{\circ} \mathrm{Z}$; this conversion also occurred for $\mathrm{AgZ}$ at a face velocity of 3.75 $\mathrm{m} / \mathrm{min}$ in the absence of $\mathrm{NO}_{\mathrm{X}}$.

- If there was very little water in the gas stream $\left(4 \times 10^{-6} \mathrm{~mole} / \mathrm{L}\right)$, the trapping efficiency of $\mathrm{Ag}^{\circ} \mathrm{Z}$ was significantly reduced (compare experiments $1-3$ and 1-4). 


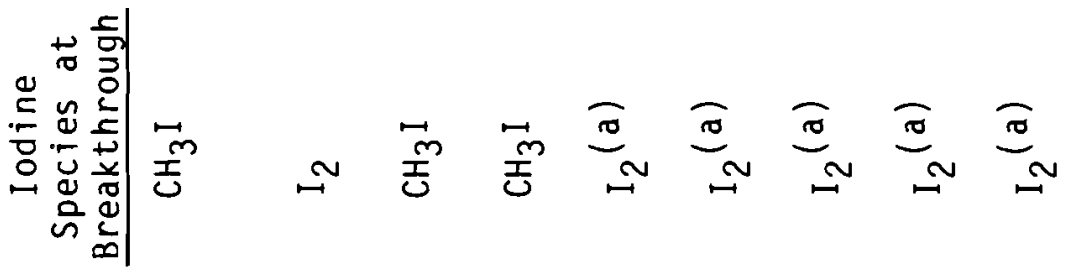

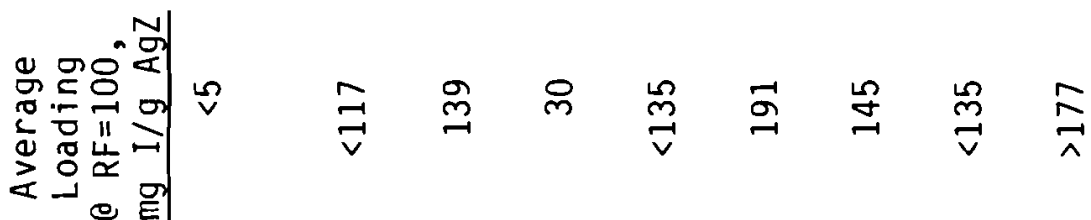

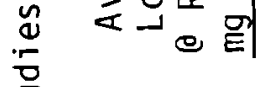

壳

品

$\frac{\pi}{0}$

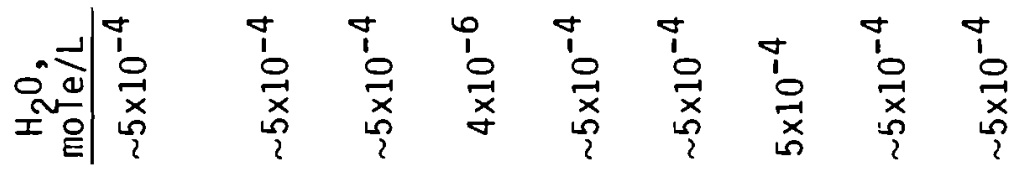

E

$\ddot{\sim}$

4

它

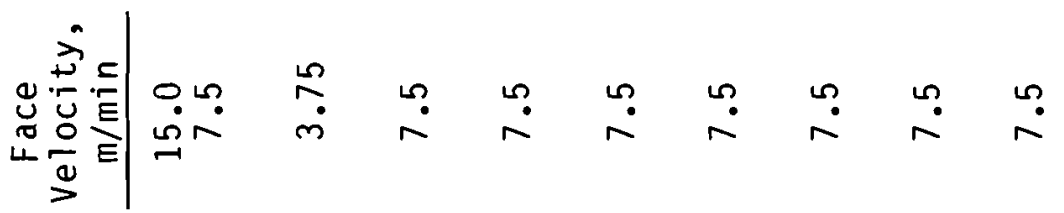

高0|윰

品

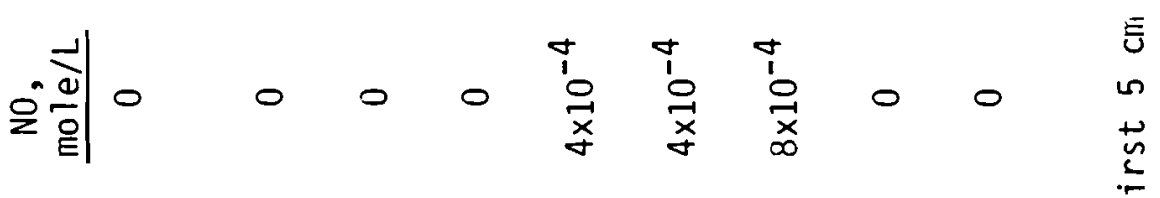

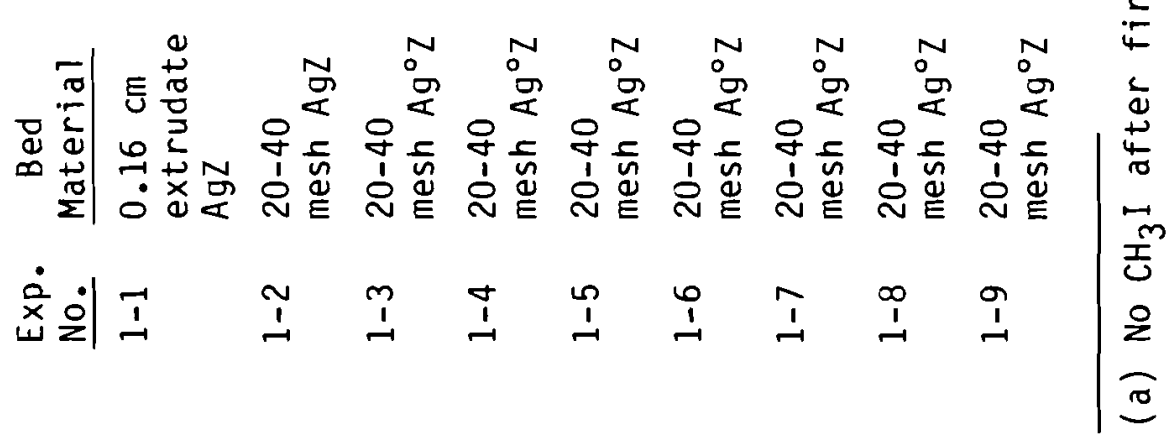


- Larger mordenite particles, $0.16 \mathrm{~cm}$ dia extrudate, had a poorer trapping efficiency than 20-40 mesh material.

- $\mathrm{AgZ}$ was less efficient than $\mathrm{Ag}^{\circ} \mathrm{Z}$ even at a lower face velocity (compare experiments $1-2$ and $1-3$ ).

- The presence of $\mathrm{NO}$ and/or $\mathrm{NO}_{2}\left(\mathrm{NO}_{x}\right)$ had mixed effects on the loading efficiency; experiments 1-3 and 1-5 appear to have comparable loadings, while experiment $1-6$ had a much greater loading under identical conditions.

- Temperature had mixed effects on loading.

Because all of the experiments in the statistical experimental plan were not completed, the individual effects of temperature, $\mathrm{NO}$, and $\mathrm{NO}_{2}$ were confounded, and thus it was difficult to extract any conclusions about any one of these individual effects from this set of data.

\section{0-cm DIA BED STUDY}

The apparent importance of face velocity suggested that we include it as a parameter. With the help of G. F. Piepel of PNL we set up a $2^{4}$ factorial design with 4 replicates of the center of the hypercube. The replicates are needed to provide an estimate of pure (random) error. In an attempt to have linear response variables, we transformed the temperature and the $\mathrm{NO}$ and $\mathrm{NO}_{2}$ concentrations. The temperature variable $x_{T}=\exp (-1 / T)$ is based on the Arrhenius equation, $k=A \exp \left(-E_{a} / T\right)$, where $k$ is the reaction rate, $A$ is the frequency factor, $E_{a}$ is the activation energy, and $T$ is temperature in degrees Kelvin.

For the $\mathrm{NO}$ and $\mathrm{NO}_{2}$ transformation variables we assumed that they reacted with $\mathrm{CH}_{3} \mathrm{I}$ as shown in equations (15) and (16) in Table 2. The $\mathrm{NO}_{x} / \mathrm{CH}_{3} \mathrm{I}$ ratios are roughly 4 and 2 , respectively. We therefore adopted the transformations

$$
x_{N O}=\left(\frac{[N O]}{-4.1 \times 10^{-4}}\right)^{1 / 4} \text { and }
$$




$$
x_{\mathrm{NO}_{2}}=\left(\frac{\left[\mathrm{NO}_{2}\right]}{4.1 \times 10^{-4}}\right)^{1 / 2}
$$

The constant $4.1 \times 10^{-4}$ is the maximum concentration employed in moles/L, and is equivalent to about 1 vol\%.

The experimental conditions, average iodine loading at breakthrough $(R F=100)$, and the iodine species found in the effluent are presented in Table 6. The first four runs 2-1 through 2-4 (Figures A.3 through A.6) were made to measure variability. The parametric study included experiments $2-5$ through 2-24. The high temperature experiments were 2-25 through 2-28. Figures A.5 through A.26 are plots of $\mathrm{CH}_{3} \mathrm{I}$ concentration in the influent, effluent from the first $8 \mathrm{~cm}$ bed segment, and the next two $5 \mathrm{~cm}$ bed segments as a function of average bed loading. In some figures the $8 \mathrm{~cm}$ bed segment was divided into 3 and $5 \mathrm{~cm}$ bed segments. (Figures are not presented for Experiments 2-9, 2-13, and 2-25 because their $\mathrm{CH}_{3} \mathrm{I}$ was converted to $\mathrm{I}_{2}$ ).

In this set of experiments performed using a larger bed and particle size, we did not typically see total conversion of all of the $\mathrm{CH}_{3} \mathrm{I}$ to $\mathrm{I}_{2}$ in the presence of $\mathrm{NO}_{X}$ as we did with the smaller particle size $\mathrm{Ag}^{\circ} \mathrm{Z}$. We did, however, see total conversion in 2-10 and 2-13, both at $150^{\circ} \mathrm{C}$ and $3.75 \mathrm{~m} / \mathrm{min}$ face velocity, one with $\mathrm{NO}_{x}$ absent and the other with $\mathrm{NO}_{x}$ present. Total conversion did occur at $200^{\circ} \mathrm{C}$ in the presence of $\mathrm{NO}_{x}$, independent of face velocity. Particle size does affect the efficiency of the $\mathrm{CH}_{3}$ I conversion to $\mathrm{I}_{2}$ on a silver mordenite bed.

Table 7 presents the results of several confirmatory $x$-ray fluorescence analyses performed by F. T. Hara and A. W. Lautensleger of PNL. In some cases the loading was not terminated at breakthrough, so the final materials contained more iodine than presented in Table 4. To extrapolate bed segment loadings at an RF of 100 , the ratio of the final average loading to the timebased average loading at an RF of 100 was found, and the final loading of each bed segment was divided by this ratio. To illustrate the accuracy of the analysis, the time-based final loading is also presented. 
TABLE 6. Summary of $5.0 \mathrm{~cm} \mathrm{Dia} \mathrm{Bed} \mathrm{Studies}$

\begin{tabular}{|c|c|c|c|c|c|c|}
\hline $\begin{array}{l}\text { Exp. } \\
\text { No. }\end{array}$ & $\begin{array}{l}\text { No), } \\
\text { mole/L }\end{array}$ & $\begin{array}{r}\mathrm{NO}_{2} \\
\mathrm{~mol} \mathrm{e} / \mathrm{L} \\
\end{array}$ & $\begin{array}{c}\text { Temp., } \\
{ }^{\circ} \mathrm{C} \\
\end{array}$ & $\begin{array}{c}\text { Face } \\
\text { Velocity, } \\
\text { m/min } \\
\end{array}$ & $\begin{array}{l}\text { Average } \\
\text { Loading } \\
0 \mathrm{RF}=100 \\
\mathrm{mg} 1 / \mathrm{g} \mathrm{Ag} \mathrm{Z}\end{array}$ & $\begin{array}{c}\text { Iodine } \\
\text { Spectes at } \\
\text { Breakthrough }\end{array}$ \\
\hline $2-1$ & 0 & 0 & 116 & 15.0 & 25 & $\mathrm{CH}_{3} \mathrm{I}$ \\
\hline $2-2$ & 0 & 0 & 116 & 15.0 & 15 & $\mathrm{CH}_{3} \mathrm{I}$ \\
\hline $2-3$ & 0 & 0 & 116 & 15.0 & 29 & $\mathrm{CH}_{3} \mathrm{I}$ (No $\mathrm{I}_{2}$ detected) \\
\hline $2-4$ & 0 & 0 & 116 & 15.0 & 22 & $\mathrm{CH}_{3} \mathrm{I}$ (No $\mathrm{I}_{2}$ detected) \\
\hline $2-5$ & $5.2 \times 10^{-5}$ & $2.6 \times 10^{-5}$ & 116 & 7.5 & 38 & $\mathrm{CH}_{3} \mathrm{I}\left(\mathrm{I}_{2}\right.$ at $\left.3 \mathrm{~cm}\right)$ \\
\hline $2-6$ & $4.1 \times 10^{-4}$ & 0 & 152 & 15.0 & 19 & $\mathrm{Cl}_{3} \mathrm{l}$ (No $I_{2}$ detected) \\
\hline $2-1$ & 0 & 0 & 86 & 15.0 & $<7$ & $\mathrm{CH}_{3} \mathrm{I}$ (No $I_{2}$ detected) \\
\hline $2-8$ & $4.1 \times 10^{-4}$ & $4.1 \times 10^{-4}$ & 152 & 15.0 & 63 & $\mathrm{CH}_{3} \mathrm{I}\left(\mathrm{I}_{2}\right.$ at $\left.13 \mathrm{~cm}\right)$ \\
\hline $2-9$ & 0 & $4.1 \times 10^{-4}$ & 152 & 3.75 & 127 & $\mathrm{I}_{2}$ (No $\mathrm{CH}_{3} \mathrm{I}$ detected) \\
\hline $2-110$ & u & u & 152 & 3.75 & 157 & $\mathrm{CH}_{3} \mathrm{I}$ and $\mathrm{I}_{2}$ \\
\hline $2-11$ & $5.2 \times 10^{-5}$ & $2.6 \times 10^{-5}$ & 116 & 7.5 & 97 & $\mathrm{CH}_{3} \mathrm{I}\left(\mathrm{I}_{2}\right.$ at $\left.13 \mathrm{~cm}\right)$ \\
\hline $2-12$ & ) & $4.1 \times 10^{-4}$ & 86 & 3.75 & 25 & $\mathrm{CH}_{3} \mathrm{I}\left(\mathrm{I}_{2}\right.$ at $\left.3 \mathrm{~cm}\right)$ \\
\hline $2-13$ & $4.1 \times 10^{-4}$ & $4.1 \times 10^{-4}$ & 152 & 3.75 & 93 & $\mathrm{I}_{2}$ (No $\mathrm{CH}_{3} \mathrm{I}$ detected) \\
\hline $2-14$ & $4.1 \times 10^{-4}$ & 0 & 86 & 3.75 & 32 & $\mathrm{CH}_{3} \mathrm{I}$ ( $\mathrm{NO} \mathrm{I}_{2}$ detected) \\
\hline $2-15$ & $4.1 \times 10^{-4}$ & $4.1 \times 10^{-4}$ & 86 & 3.75 & 21 & $\mathrm{CH}_{3} \mathrm{I}$ (No $\mathrm{I}_{2}$ detected) \\
\hline $2-16$ & $4.1 \times 10^{-4}$ & 0 & 86 & 15.0 & 15 & $\mathrm{CH}_{3} \mathrm{I}$ ( $\mathrm{No} \mathrm{I}_{2}$ detected) \\
\hline $2-17$ & $5.2 \times 10^{-5}$ & $2.6 \times 10^{-5}$ & 116 & 7.5 & 105 & $\mathrm{CH}_{3} \mathrm{I}\left(\mathrm{I}_{2}\right.$ at $\left.3 \mathrm{~cm}\right)$ \\
\hline $2-18$ & 0 & 0 & 152 & 15.0 & 47 & $\mathrm{CH}_{3} \mathrm{I}$ ( $\mathrm{No} \mathrm{I}_{2}$ detected) \\
\hline $2-19$ & 0 & $4.1 \times 10^{-4}$ & 152 & 15.0 & 55 & $\mathrm{CH}_{3} \mathrm{I}\left(\mathrm{I}_{2}\right.$ at $\left.13 \mathrm{~cm}\right)$ \\
\hline $2-20$ & 0 & 0 & 86 & 3.75 & 71 & $\mathrm{CH}_{3} \mathrm{I}$ (No $\mathrm{I}_{2}$ detected) \\
\hline $2-21$ & 0 & $4.1 \times 10^{-4}$ & 86 & 15.0 & 15 & $\mathrm{CH}_{3} \mathrm{I}$ ( $\mathrm{No} \mathrm{I}_{2}$ detected) \\
\hline $2-22$ & $4.1 \times 10^{-4}$ & $4.1 \times 10^{-4}$ & 86 & 15.0 & 6 & $\mathrm{CH}_{3} \mathrm{I}$ (No $\mathrm{I}_{2}$ detected) \\
\hline $2-23$ & $4.1 \times 10^{-4}$ & 0 & 152 & 3.75 & 91 & $\mathrm{CH}_{3} \mathrm{I}$ and $\mathrm{I}_{2}$ \\
\hline $2-24$ & $5.2 \times 10^{-5}$ & $2.6 \times 10^{-5}$ & 116 & 7.5 & 47 & $\mathrm{CH}_{3} !\left(\mathrm{I}_{2}\right.$ at $\left.13 \mathrm{~cm}\right)$ \\
\hline $2-25$ & $4.1 \times 10^{-4}$ & $4.1 \times 10^{-4}$ & 200 & 3.75 & 76 & $I_{2}\left(\right.$ No $\mathrm{CH}_{3} \mathrm{I}$ detected) \\
\hline $2-26$ & 0 & 0 & 200 & 3.75 & 217 & $\mathrm{I}_{2}$ and $\mathrm{CH}_{3} I$ \\
\hline $2-27$ & 0 & 0 & 200 & 15.0 & 169 & $\mathrm{I}_{2}$ and $\mathrm{CH}_{3} \mathrm{I}$ \\
\hline $2-28$ & $4.1 \times 10^{-4}$ & $4.1 \times 10^{-4}$ & 200 & 15.0 & 88 & $\mathrm{I}_{2}$ (No $\mathrm{CH}_{3} \mathrm{I}$ detected) \\
\hline
\end{tabular}


TABLE 7. Summary of Iodine Loading by Bed Segment

\begin{tabular}{|c|c|c|c|c|}
\hline $\begin{array}{l}\text { Exp. } \\
\text { No.. } \\
\end{array}$ & Bed Segment (a) & $\begin{array}{l}\text { Estimated (b) } \\
\text { Iodine Loading } \\
\text { at an } \mathrm{RF}=100 \text {, } \\
\mathrm{mg} \mathrm{I/g} \mathrm{Ag} \mathrm{Z} \\
\end{array}$ & $\begin{array}{c}\text { Measured Iodine }(\mathrm{c}) \\
\text { Loading at End } \\
\text { of Loading, } \\
\mathrm{mg} \mathrm{I} / \mathrm{g} \mathrm{Ag} Z \\
\end{array}$ & $\begin{array}{c}\text { Time Calculated } \\
\text { Iodine Loading at } \\
\text { Experiment End, } \\
\mathrm{mg} \mathrm{I/g} \mathrm{Ag} \mathrm{Z} \\
\end{array}$ \\
\hline \multirow[t]{5}{*}{$2-5$} & $1 \mathrm{~A}$ & 59 & 139 & \\
\hline & $1 B$ & 60 & 141 & \\
\hline & 2 & 33 & 80 & \\
\hline & 3 & 8 & 19 & \\
\hline & Ave & 38 & 90 & 85 \\
\hline \multirow[t]{5}{*}{$2-11$} & $1 A$ & 108 & 137 & \\
\hline & 1B & 126 & 160 & \\
\hline & 2 & 114 & 144 & \\
\hline & 3 & 44 & 56 & \\
\hline & Ave & 97 & 123 & 127 \\
\hline \multirow[t]{5}{*}{$2-17$} & $1 A$ & 150 & 173 & \\
\hline & $1 B$ & 143 & 164 & \\
\hline & 2 & 90 & 104 & \\
\hline & 3 & 55 & 63 & \\
\hline & Ave & 105 & 121 & 112 \\
\hline \multirow[t]{5}{*}{$2-24$} & $1 A$ & 71 & 142 & \\
\hline & $1 \mathrm{~B}$ & 72 & 145 & \\
\hline & 2 & 36 & 71 & \\
\hline & 3 & 18 & 36 & \\
\hline & Ave & 47 & 94 & 95 \\
\hline \multirow[t]{5}{*}{$2-25$} & $1 \mathrm{~A}$ & & 75 & \\
\hline & $1 B$ & & 91 & \\
\hline & 2 & & 122 & \\
\hline & 3 & & 82 & \\
\hline & Ave & $76^{(d)}$ & 94 & 76 \\
\hline
\end{tabular}


TABLE 7. (contd)

\begin{tabular}{|c|c|c|c|c|}
\hline $\begin{array}{l}\text { Exp. } \\
\text { No. }\end{array}$ & Bed Segment (a) & $\begin{array}{l}\text { Estimated }(\mathrm{b}) \\
\text { Iodine Loading } \\
\text { at an } \mathrm{RF}=100 \text {, } \\
\mathrm{mg} \mathrm{I} / \mathrm{g} \mathrm{Ag} \mathrm{Z} \\
\end{array}$ & $\begin{array}{c}\text { Measured Iodine }(\mathrm{c}) \\
\text { Loading at End } \\
\text { of Loading, } \\
\mathrm{mg} \mathrm{I} / \mathrm{g} \mathrm{Ag} \mathrm{Ag}^{\circ} \\
\end{array}$ & $\begin{array}{l}\text { Time Calculated } \\
\text { Iodine Loading at } \\
\text { Experiment End, } \\
\mathrm{mg} \mathrm{I} / \mathrm{g} \mathrm{Ag} \mathrm{g}^{\circ} \\
\end{array}$ \\
\hline \multirow[t]{5}{*}{$2-26$} & $1 \mathrm{~A}$ & 221 & 232 & \\
\hline & $1 B$ & 219 & 230 & \\
\hline & 2 & 219 & 230 & \\
\hline & 3 & 212 & 223 & \\
\hline & Ave & 217 & 228 & 250 \\
\hline \multirow[t]{5}{*}{$2-27$} & $1 \mathrm{~A}$ & 189 & 216 & \\
\hline & $1 B$ & 174 & 199 & \\
\hline & 2 & 177 & 202 & \\
\hline & 3 & 144 & 164 & \\
\hline & Ave. & 169 & 193 & 240 \\
\hline \multirow[t]{5}{*}{$2-28$} & $1 \mathrm{~A}$ & & 116 & \\
\hline & 1B & & 108 & \\
\hline & 2 & & 100 & \\
\hline & 3 & & 62 & \\
\hline & Ave & $88^{(d)}$ & 94 & 88 \\
\hline
\end{tabular}

(a) The bed, when removed, was segmented as $1 \mathrm{~A}$, top $3 \mathrm{~cm}$; $1 \mathrm{~B}$ next $5 \mathrm{~cm} ; 2$, next $5 \mathrm{~cm}$; and 3 , next $5 \mathrm{~cm}$.

(b) Estimated loading was calculated for each segment by multiplying the measured iodine content on that segment by the ratio of the timecalculated total bed average to the measured total bed average.

(c) Determined by $X$-ray fluorescence analysis.

(d) Experiment stopped at RF $=100$. Time-calculated loading at end. Segment loading should be same as $X$-ray analysis.

Inspection of the loadings by bed segment shows mass transfer zones ranging from $10 \mathrm{~cm}$ (experiment 2-5) to less than $5 \mathrm{~cm}$ (experiment 2-26).

As mentioned earlier, the maximum theoretical loading, assuming $\mathrm{AgI}$ as the product, is $225 \mathrm{mg} \mathrm{I} / \mathrm{g} \mathrm{AgZ}$. Experiment $2-26$, loaded at $200^{\circ} \mathrm{C}$ in the absence of $\mathrm{NO}_{x}$, has nearly the maximum theoretical loading. 
DATA ANALYSIS

A statistical analysis of the results was performed by $W$. M. Bowen of PNL. To determine whether a variable affected $\mathrm{CH}_{3} \mathrm{I}$ capture, an extensive analysis of variance (ANOVA) was performed using a statistical computer package.

An ANOVA (e.g., Table 8) attempts to analyze the variation found for a dependent variable (response) by attributing portions of the response variation to independent variables (sources). There are two basic sources of response variation: 1) random or pure error variation, caused by factors which are not or cannot be controlled; and 2) variations caused by changes in the levels of the source variables which were controlled in the experiment.

The theory and methodology of ANOVA is too complex to be discussed here, so we will only provide a brief explanation in general terms. For further information, reading Snedecor and Cochran (1980) is suggested.

ANOVA partitions the total variability in the response variable into portions attributable to each independent variable. The Sum of Squares (SS) or Mean Square (MS) for each independent variable is a measure of the portion of the total variability accounted for by the effect of the independent variable on the response variable. To determine whether the effect of this independent variable is statistically significant, its MS is divided by the Mean Square due to experimental error (MSE). When there is no effect, this ratio follows the $F$ distribution. When there is an effect, the ratio will tend to be larger than an $F$ distributed variable. Thus, the ratio is compared with a value obtained from a Table of the $F$ distribution. The independent variable has a statistically significant effect if the ratio exceeds the table value. The significance level reported in the ANOVA table is the probability of being wrong in concluding that the independent variable actually has an effect beyond variations due to experimental error. Thus, a small significant level provides greater confidence in concluding that there actually is an effect.

The analysis was performed in two phases. The first (Phase 1) analyzed the data from experiments 2-5 to 2-24. The second (Phase II) added the results 
TABLE 8. Full Model ANOVA for Phase 1 Analysis

Source

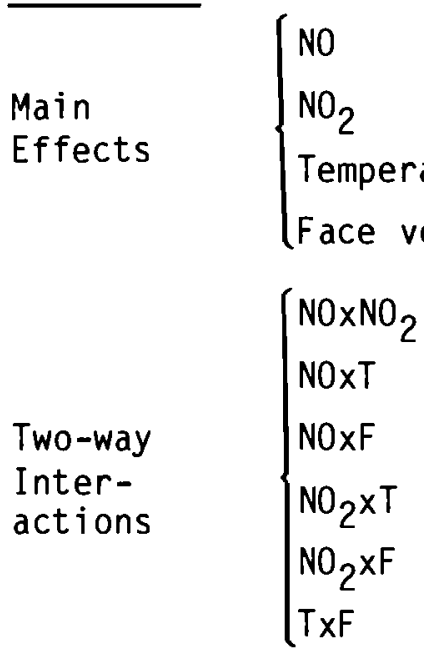

Three-way
Inter-
actions $\quad\left\{\begin{array}{l}\mathrm{NO}^{\mathrm{NONO}} \mathrm{N}_{2} \times \mathrm{T} \\ \mathrm{NO} \mathrm{NO}_{2} \times \mathrm{F} \\ \mathrm{NO} \times \mathrm{T} \times \mathrm{F} \\ \mathrm{NO}_{2} \times \mathrm{T} \times \mathrm{F}\end{array}\right.$

Four-way

Inter-

action

$\mathrm{NO} \times \mathrm{NO}_{2} \times \mathrm{T} \times \mathrm{F}$
Degrees Sum of Variance Significance

1

$72.3<1$

$13225.0 \quad 11.35 \quad 0.05$

$9506.3 \quad 8.16 \quad 0.10$

$462.3<1$

$361.0<1$

$930.3<1$

$90.3<1$

$1156.0<1$

$1980.3 \quad 1.70$

$156.3<1$

$144.0<1$

$\begin{array}{rrr}1 & 90.3<1 \\ 1 & 36.0<1 \\ 1 & 196.0<1\end{array}$

$\begin{array}{rrr}1 & 90.3<1 \\ 1 & 36.0<1 \\ 1 & 196.0<1\end{array}$

$\begin{array}{rrr}1 & 90.3<1 \\ 1 & 36.0<1 \\ 1 & 196.0<1\end{array}$

$\begin{array}{lrr}1 & 90.3 & <1 \\ 1 & 36.0 & <1 \\ 1 & 196.0 & <1\end{array}$

Lack-of-fit

$1155.0<1$
3495

MSE $=1165$

from the experiments (2-25 through 2-28) performed at $200^{\circ} \mathrm{C}$. The results of each phase were similar, as discussed in detail below. Temperature and face velocity had the greatest effects, NO had a lesser effect, and $\mathrm{NO}_{2}$ had no effect. The highest iodine loadings were obtained at higher temperatures, lower face velocities, and in the absence of NO. Complex interactions were found between the different independent variables; i.e., the effect of one variable is affected by the level of another variable. 
Phase 1 Analysis

Initially an ANOVA was performed to test the significance of the 4 main factors, 6 two-way interactions, 4 three-way interactions, and 1 four-way interaction, and to test for lack-of-fit. A statistically significant main effect indicates that the corresponding factor had a linear effect on the response variable, which is average bed loading at an RF of 100. A significant two-way interaction means that the effect of one variable depends on the level of a second variable and vice versa. The same applies to the three-way and four-way interactions. The lack-of-fit test indicates whether any of the factors had other than simple linear effects.

The results of the initial ANOVA, which are presented in Table 8, indicate that lack-of-fit, the three-way and four-way interactions are not significant. Thus, these could be "pooled" with pure experimental error to provide an improved estimate of pure experimental error and a reduced model tested by ANOVA.

The reduced ANOVA results are presented in Table 9. We find that the temperature $(T)$ and superficial face velocity (F) have significant main effects, and that they interact (TXF symbolizes the interaction of temperature and face velocity). These linear effects and interactions are illustrated in Figures 4 and 5 . In the figures the mean bed loadings appear in parentheses.

Figure 4 indicates that bed loading increases with increasing temperature, and this increase is greater at low face velocity. However, the relative loadings $\left[L\left(T_{2}\right) / L\left(T_{1}\right)\right]$ are not very different, being slightly greater at the high velocity. The nature of the interdependence of $F$ and $T$, as seen in Figures 4 and 5, is unclear. From the low loadings at the lower temperature, it is apparent that the silver sites are effectively blocked; i.e., the $\mathrm{CH}_{3} \mathrm{I}$ residence time is not adequate at either flow rate.

The main effect of $\mathrm{NO}$ and the two-way interactions of $\mathrm{NOXF}$ and $\mathrm{NO}_{2} \times \mathrm{F}$ were significant at the 0.25 level. Figures 6 and 7 show the effects of $\mathrm{NO}$ and $\mathrm{NO}_{2}$ at the two levels of face velocities, respectively. The introduction of NO reduced the mean loading; this effect was greater at $3.75 \mathrm{~m} / \mathrm{min}$ than at $15 \mathrm{~m} / \mathrm{min}$. As discussed in the Phase 2 section, it appears that $\mathrm{NO}$ blocked, 
TABLE 9. Reduced Model ANOVA for Phase 1 Analysis

\begin{tabular}{|c|c|c|c|c|}
\hline Source & $\begin{array}{l}\text { Degrees } \\
\text { of Freedom }\end{array}$ & $\begin{array}{l}\text { Sum of } \\
\text { Squares }\end{array}$ & $\begin{array}{l}\text { Variance } \\
\text { Ratio } \\
\end{array}$ & $\begin{array}{c}\text { Significance } \\
\text { Level }\end{array}$ \\
\hline NO & 1 & 1681.0 & 2.87 & 0.25 \\
\hline $\mathrm{NO}_{2}$ & 1 & 72.3 & $<1$ & \\
\hline Temperature (T) & 1 & 13225.0 & 22.57 & 0.005 \\
\hline Face Velocity (F) & 1 & 9506.3 & 16.23 & 0.005 \\
\hline $\mathrm{NO} \times \mathrm{NO}_{2}$ & 1 & 462.3 & $<1$ & \\
\hline NOXT & 1 & 361.0 & $<1$ & \\
\hline $\mathrm{NO} \times \mathrm{F}$ & 1 & 930.3 & 1.59 & 0.25 \\
\hline $\mathrm{NO}_{2} \times \mathrm{T}$ & 1 & 420.2 & $<1$ & \\
\hline $\mathrm{NO}_{2} \times \mathrm{F}$ & 1 & 1156.0 & 1.97 & 0.25 \\
\hline$T \times F$ & 1 & 1980.3 & 3.38 & 0.10 \\
\hline
\end{tabular}

competed with, or inhibited the reaction of $\mathrm{CH}_{3} \mathrm{I}$ with the active sites in $\mathrm{Ag}^{\circ} \mathrm{Z}$. The effect of $\mathrm{NO}_{2}$ was mixed. At $3.75 \mathrm{~m} / \mathrm{min}$, a decrease in mean loading occurred, while at $15 \mathrm{~m} / \mathrm{min}$, a slight increase in mean loading occurred. The effect was greater at the low face velocity.

Phase 2 Analysis

In phase 2 all 28 data points were included in the analysis. The same process of eliminating statistically nonsignificant effects and estimating a "pooled" variance was performed. The results of the reduced model ANOVA are presented in Table 10. Because of the incomplete design at $200^{\circ} \mathrm{C}$, where we only evaluated the presence or absence of $\mathrm{NO}_{x}$, the effects of $\mathrm{NO}$ and $\mathrm{NO}_{2}$ are completely confounded at this temperature. Thus the $\mathrm{NOXT}$ and $\mathrm{NO}_{2} \times \mathrm{T}$ two-way interactions are partially confounded for all temperatures. Therefore, for this analysis it was assumed that $\mathrm{NO}_{2} \times T$ is negligible based on the Phase I analysis.

Table 10 shows that $\mathrm{NO}_{2}$ main effect, $\mathrm{NO}_{2} \mathrm{NO}_{2}$ and $\mathrm{NO}_{2} \times \mathrm{T}$ two-way interactions, and the three-way and four-way interactions were nonsignificant. Note 


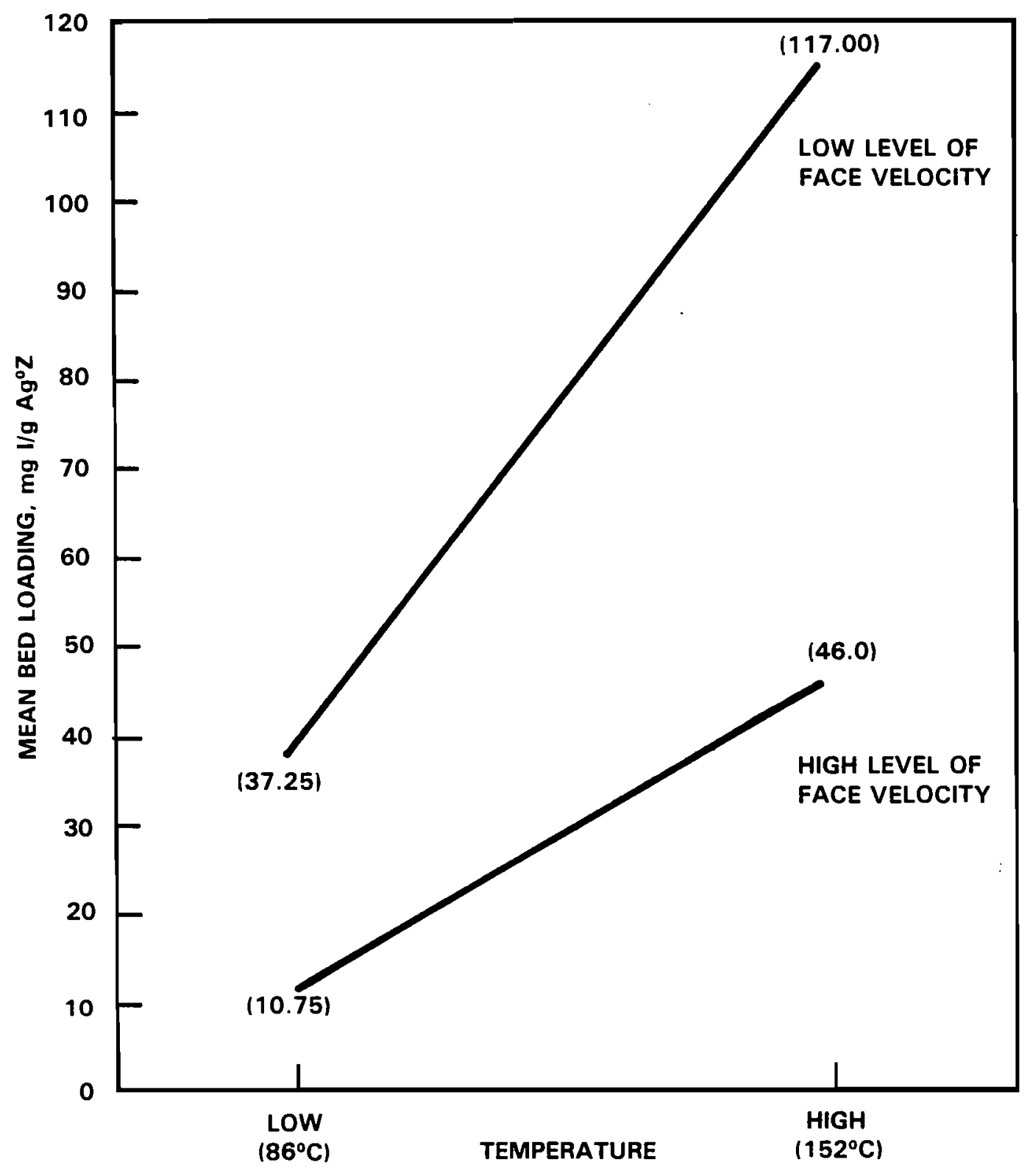

FIGURE 4. Phase 1 Analysis: The Effect of Temperature on $\mathrm{CH}_{3} \mathrm{I}$ Capture by $\mathrm{Ag}^{\circ} \mathrm{Z}$ at Face Velocities of 3.75 and $15 \mathrm{~m} / \mathrm{min}$ 


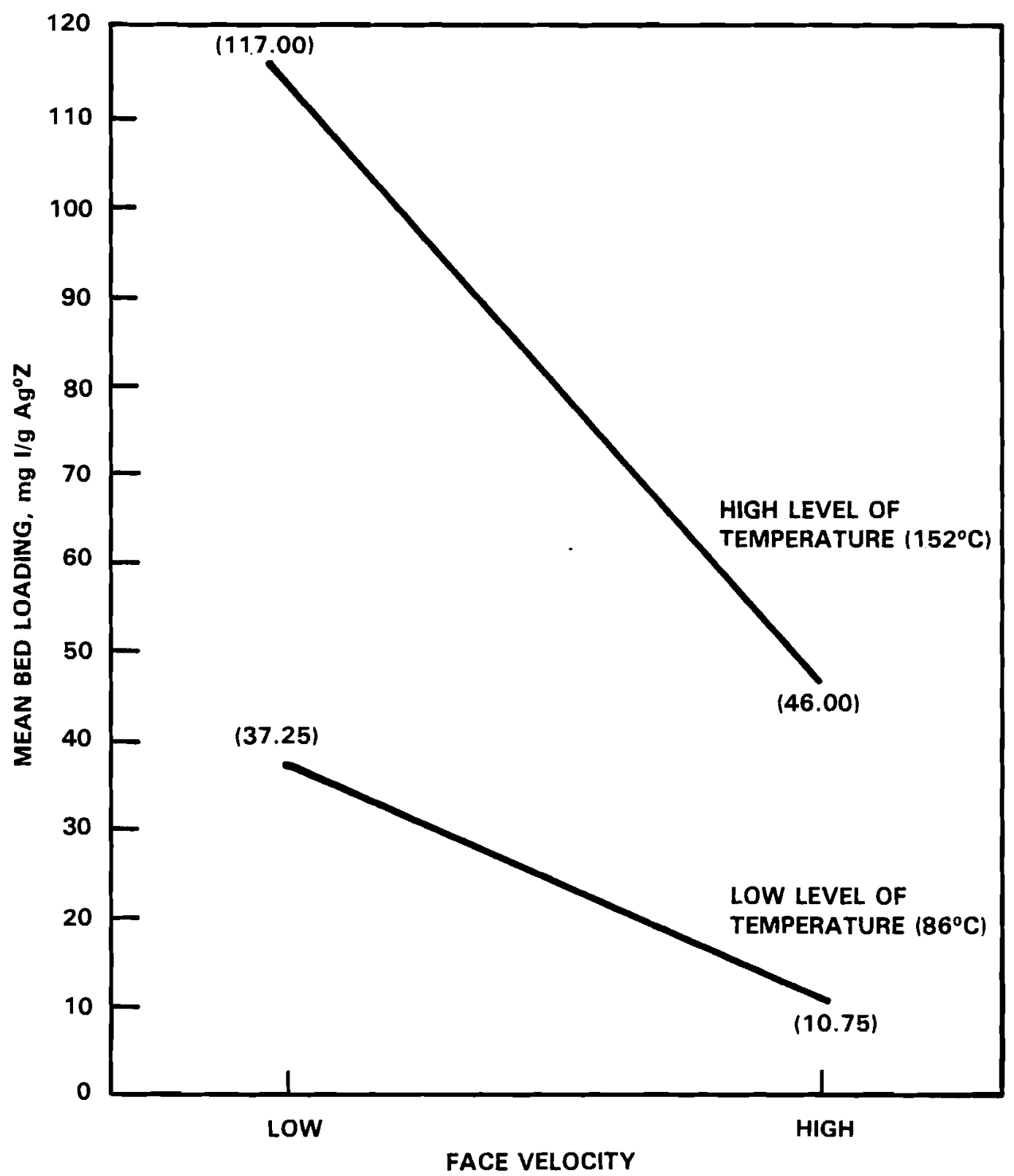

FIGURE 5. Phase 1 Analysis: The Effect of Face Velocity on $\mathrm{CH}_{3} \mathrm{I}$ Capture by $\mathrm{Ag}^{\circ} \mathrm{Z}$ at 86 and $152^{\circ} \mathrm{C}$ 


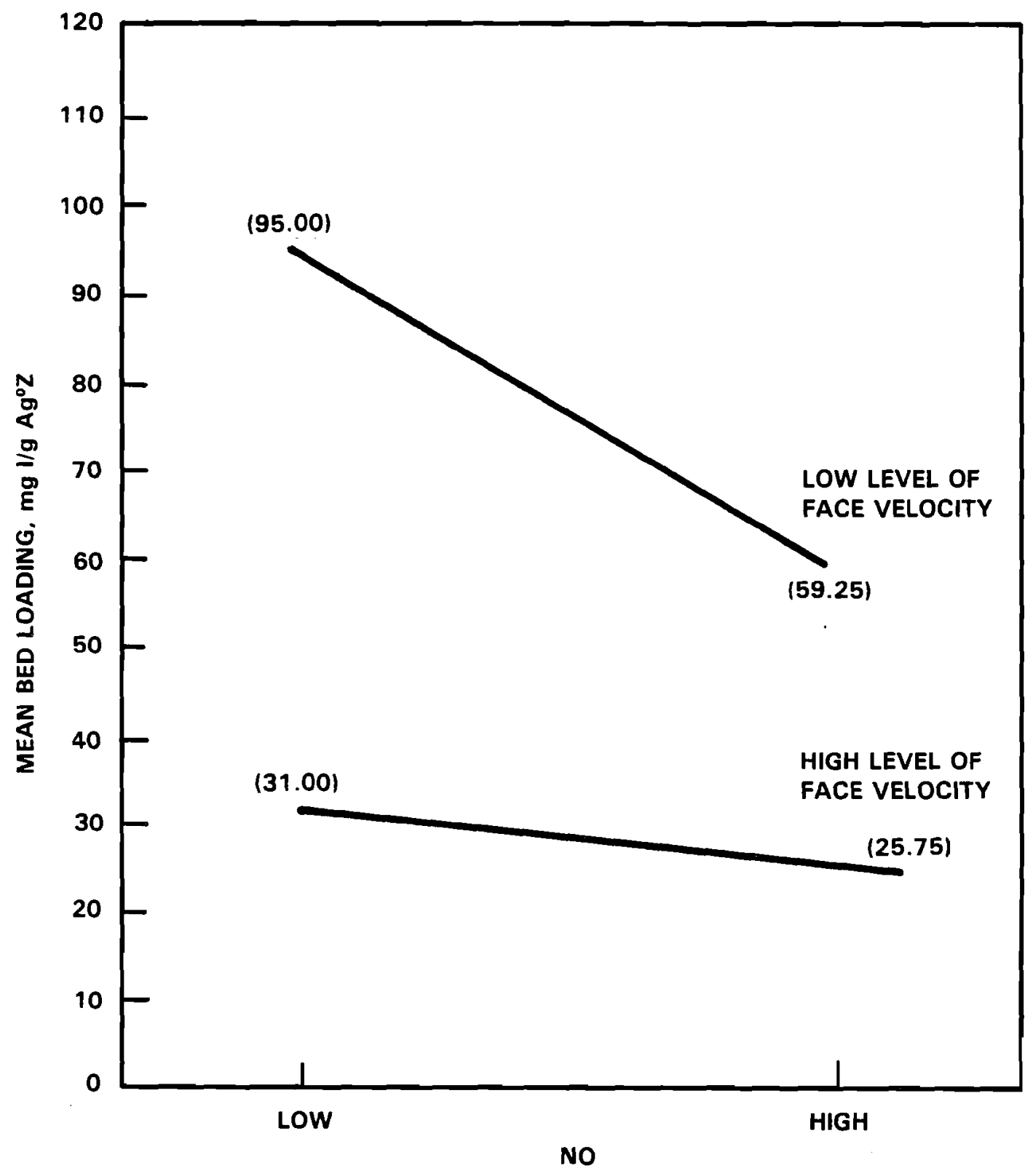

FIGURE 6. Phase 1 Analysis: The Effect of $\mathrm{NO}$ on $\mathrm{CH}_{3} \mathrm{I}$ Capture by $\mathrm{Ag}^{\circ} \mathrm{Z}$ at Face Velocities of 3.75 and $15.0 \mathrm{~m} / \mathrm{min}$ 


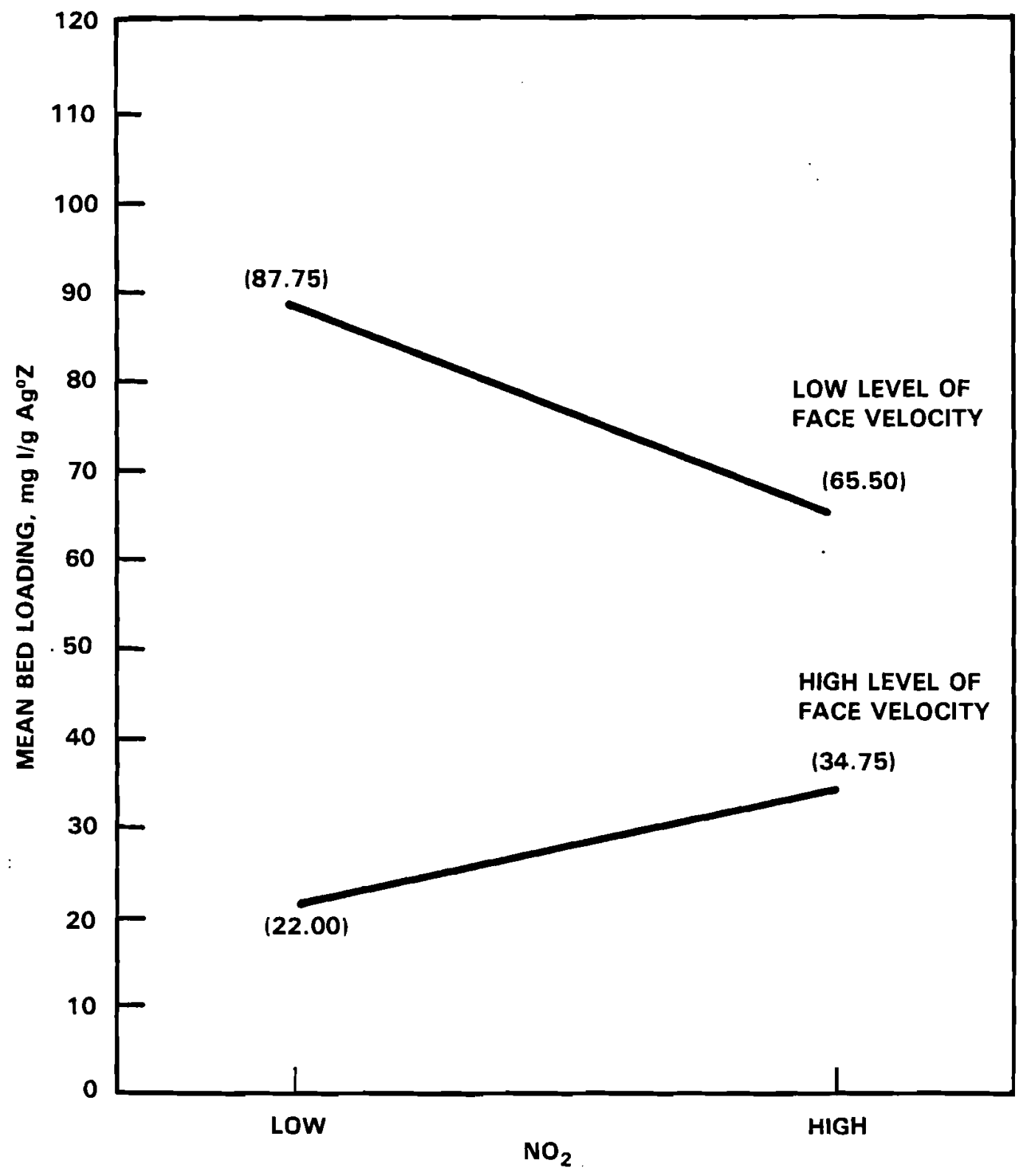

FIGURE 7. Phase 1 Analysis: The Effects of $\mathrm{NO}_{2}$ on $\mathrm{CH}_{3}$ I Capture by $\mathrm{Ag}^{\circ} \mathrm{Z}$ at Face Velocities of 3.75 and $15.0 \mathrm{~m} / \mathrm{min}$ 
TABLE 10. Reduced Model ANOVA For Phase 2 Analysis

\begin{tabular}{|c|c|c|c|c|c|}
\hline Source & $\begin{array}{l}\text { Degrees } \\
\text { Freedom }\end{array}$ & $\begin{array}{l}\text { Sum of } \\
\text { Squares }\end{array}$ & $\begin{array}{c}\text { Mean Sum } \\
\text { of Squares } \\
\end{array}$ & $\begin{array}{c}\text { Variance } \\
\text { Ratio } \\
\end{array}$ & $\begin{array}{c}\text { Significance } \\
\text { Level }\end{array}$ \\
\hline NO & 1 & 8133 & 8133 & 20.49 & 0.0005 \\
\hline Temperature $(\mathrm{T})$ & 2 & 34365 & 17183 & 43.28 & 0.0005 \\
\hline Contrast 1 (C1) & (1) & 13225 & 13225 & 33.31 & 0.0005 \\
\hline Contrast 2 (C2) & (1) & 21140 & 21140 & 53.25 & 0.0005 \\
\hline Face velocity $(F)$ & 1 & 12225 & 12225 & 30.87 & 0.0005 \\
\hline NOXT & 2 & 5871 & 2936 & 7.40 & 0.01 \\
\hline $\mathrm{NO} \times \mathrm{Cl}$ & (1) & 361 & 361 & 1 & \\
\hline $\mathrm{NO} \times \mathrm{C} 2$ & (1) & 5510 & 5510 & 13.88 & 0.005 \\
\hline NOXF & 1 & 2690 & 2690 & 6.78 & 0.025 \\
\hline $\mathrm{NO}_{2} \times \mathrm{F}$ & 1 & 3118 & 3118 & 7.85 & 0.025 \\
\hline TxF & 2 & 2400 & 1200 & 3.02 & 0.10 \\
\hline ClxF & (1) & 1980 & 1980 & 4.99 & 0.05 \\
\hline $\mathrm{C} 2 \mathrm{xF}$ & (1) & 420 & 420 & 1.06 & \\
\hline Lack-of-fit & 1 & 4562 & 4562 & 11.49 & 0.005 \\
\hline Error & 16 & 6351 & MSE $=397$ & & \\
\hline
\end{tabular}

also in Table 10 that temperature is partitioned into two contrasts. Contrast 1 is the same analysis used in Phase 1 . Contrast 2 (C2) compares the average of the means at 86 and $152^{\circ} \mathrm{C}$ with the mean at $200^{\circ} \mathrm{C}$.

There are three significant terms in Table 10 which are not in Table 9: lack-of-fit, C2, and NOxC2. Figure 8 illustrates the NOXT interaction. When NO was present, bed loading sharply increased as $T$ was increased from 152 to $200^{\circ} \mathrm{C}$. At $1 \% \mathrm{NO}$, there is only a slight increase between 152 and $200^{\circ} \mathrm{C}$.

Figures 9 and 10 illustrate the $\mathrm{NOxF}$ and $\mathrm{NO}_{2} \times \mathrm{F}$ two-way interactions, respectively. These are consistent with the results from Phase 1 (see Figures 6 and 7). At high face velocity, $15 \mathrm{~m} / \mathrm{min}$, NO and $\mathrm{NO}_{2}$ have no effect, while at low face velocity, they significantly reduce the mean loading. 


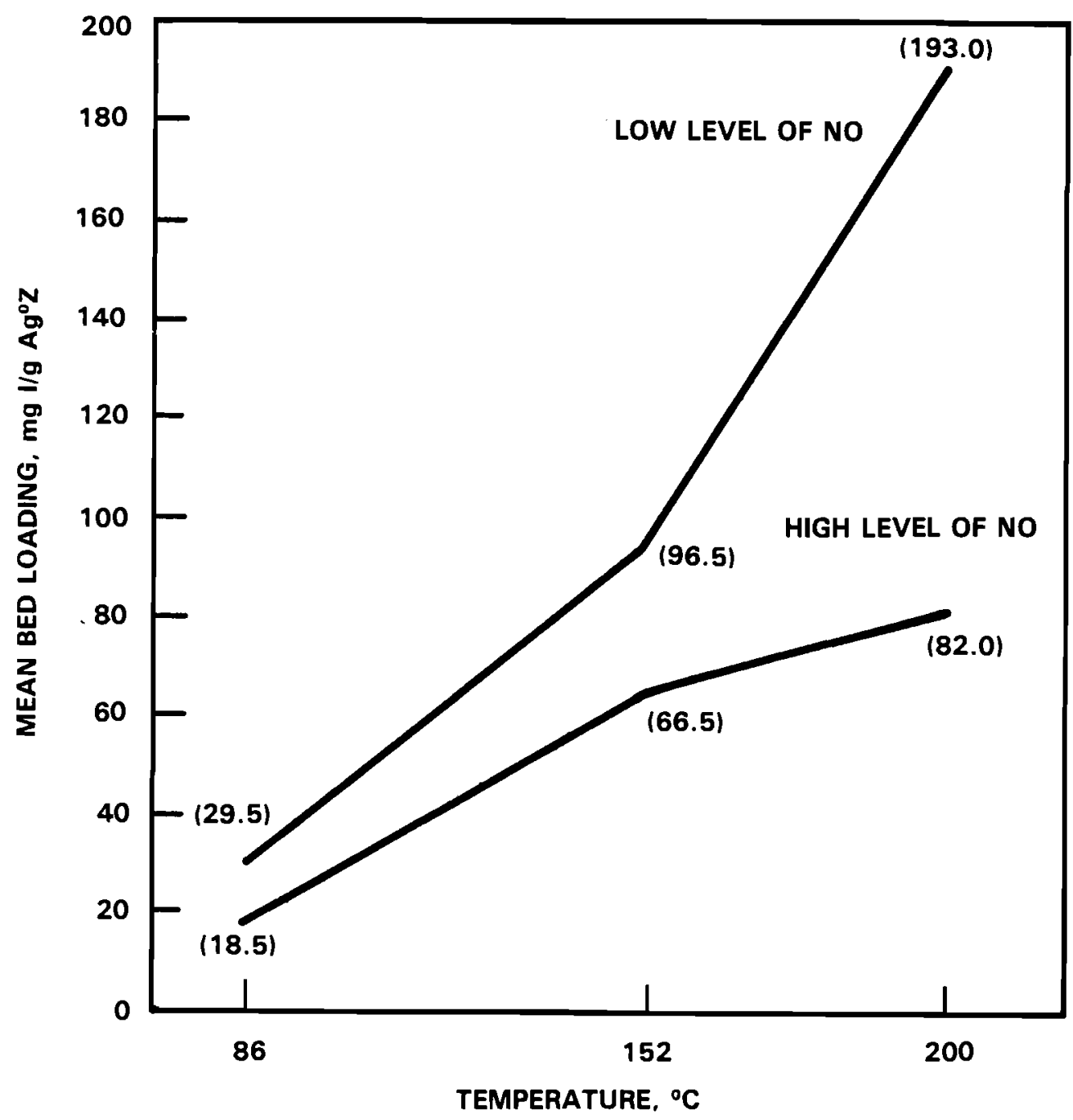

FIGURE 8. Phase 2 Analysis: The Effect of Temperature on $\mathrm{CH}_{3} \mathrm{I}$ Capture by $\mathrm{Ag}^{\circ} \mathrm{Z}$ at 0 and 2 vol\% NO

The typically negative effects seen for the oxides of nitrogen, especially NO, can be attributed to a number of factors. Included in this list are reaction or complex formation between the $\mathrm{NO}_{x}$ species, their condensation products, or their disproportionation products with the active silver; or reaction with the iodine-silver forms; or physical blockage of the zeolite pores, hindering access of the iodine to the active silver sites. Too little information is available to define the correct mechanism or combination of mechanisms. 


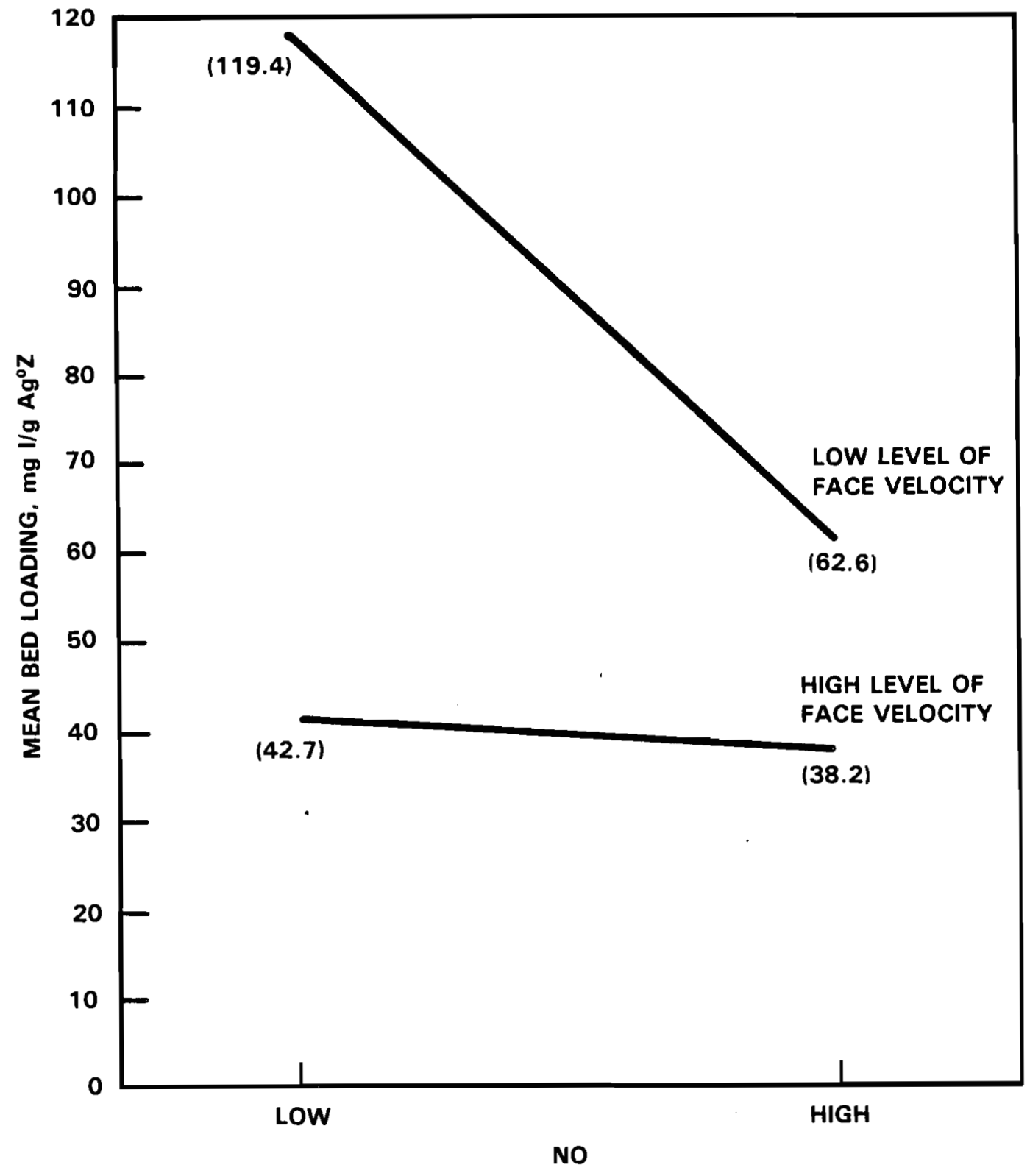

FIGURE 9. Phase 2 Analysis: The Effect of $\mathrm{NO}$ on $\mathrm{CH}_{3} \mathrm{I}$ Capture by $\mathrm{Ag}^{\circ} \mathrm{Z}$ at Face Velocities of 3.75 and $15.0 \mathrm{~m} / \mathrm{min}$ 


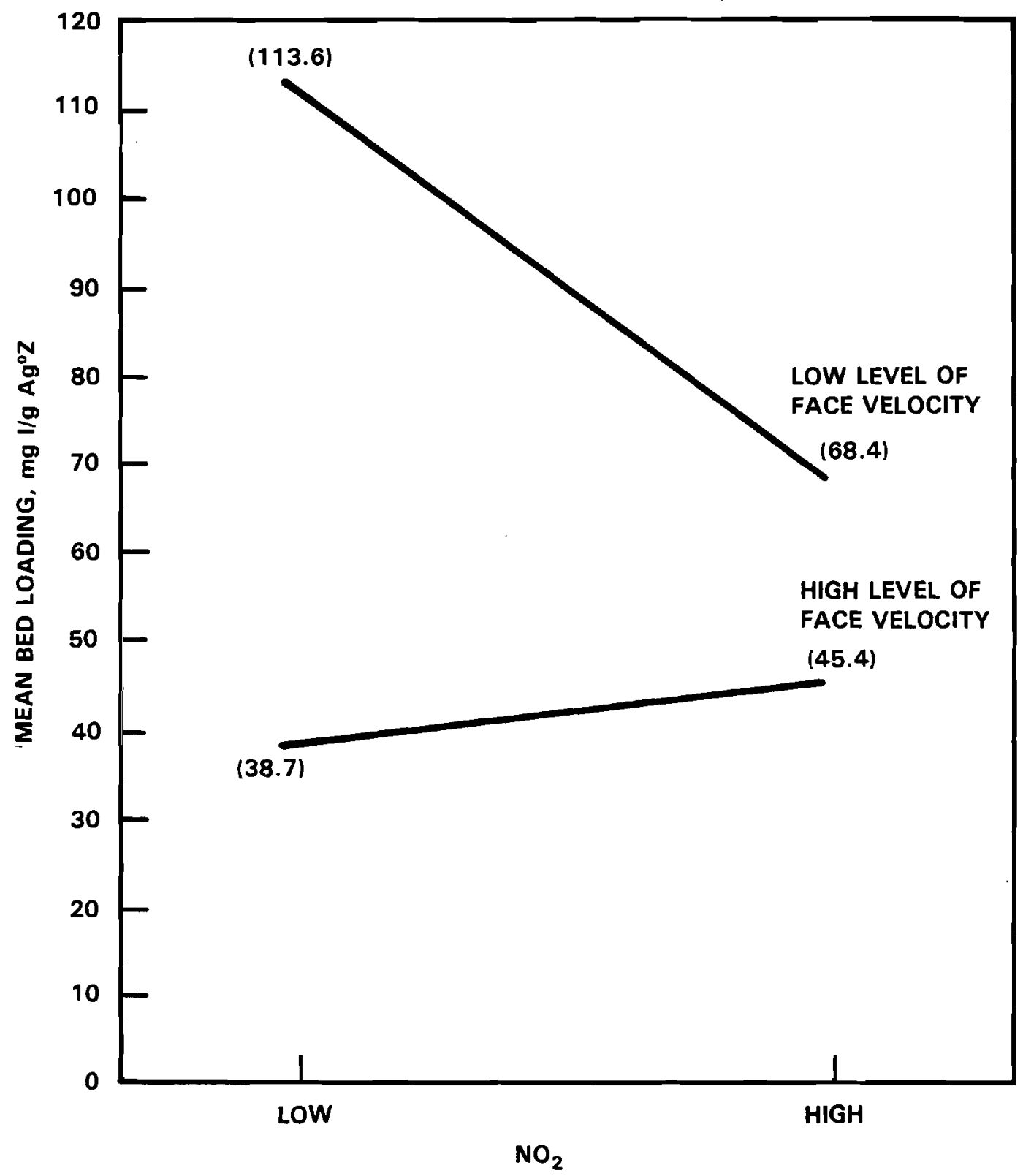

FIGURE 10. Phase 2 Analysis: The Effect of $\mathrm{NO}_{2}$ on $\mathrm{CH}_{3}$ I Capture by $\mathrm{Ag}^{\circ} \mathrm{Z}$ at Face Velocities of 3.75 and $15.0 \mathrm{~m} / \mathrm{min}$ 
Figures 11 and 12 are two illustrations of the TxF interaction. When $T$ was set at 86 or $200^{\circ} \mathrm{C}$, face velocity had only a slight effect; however, when T was at $152^{\circ} \mathrm{C}$, a sharp decrease in loading was seen when $\mathrm{F}$ was increased.

The loading at breakthrough increases with temperature over the complete range, as expected. If we assume that rates are proportional to loadings, admittedly questionable, then the calculated activation energies are smal1, (5 to $10 \mathrm{kcal})$. The fact that the loadings are not linear with the transformed temperature, i.e., exp $(-1 / T)$, over the complete range is not surprising in view of the interactions just discussed. 


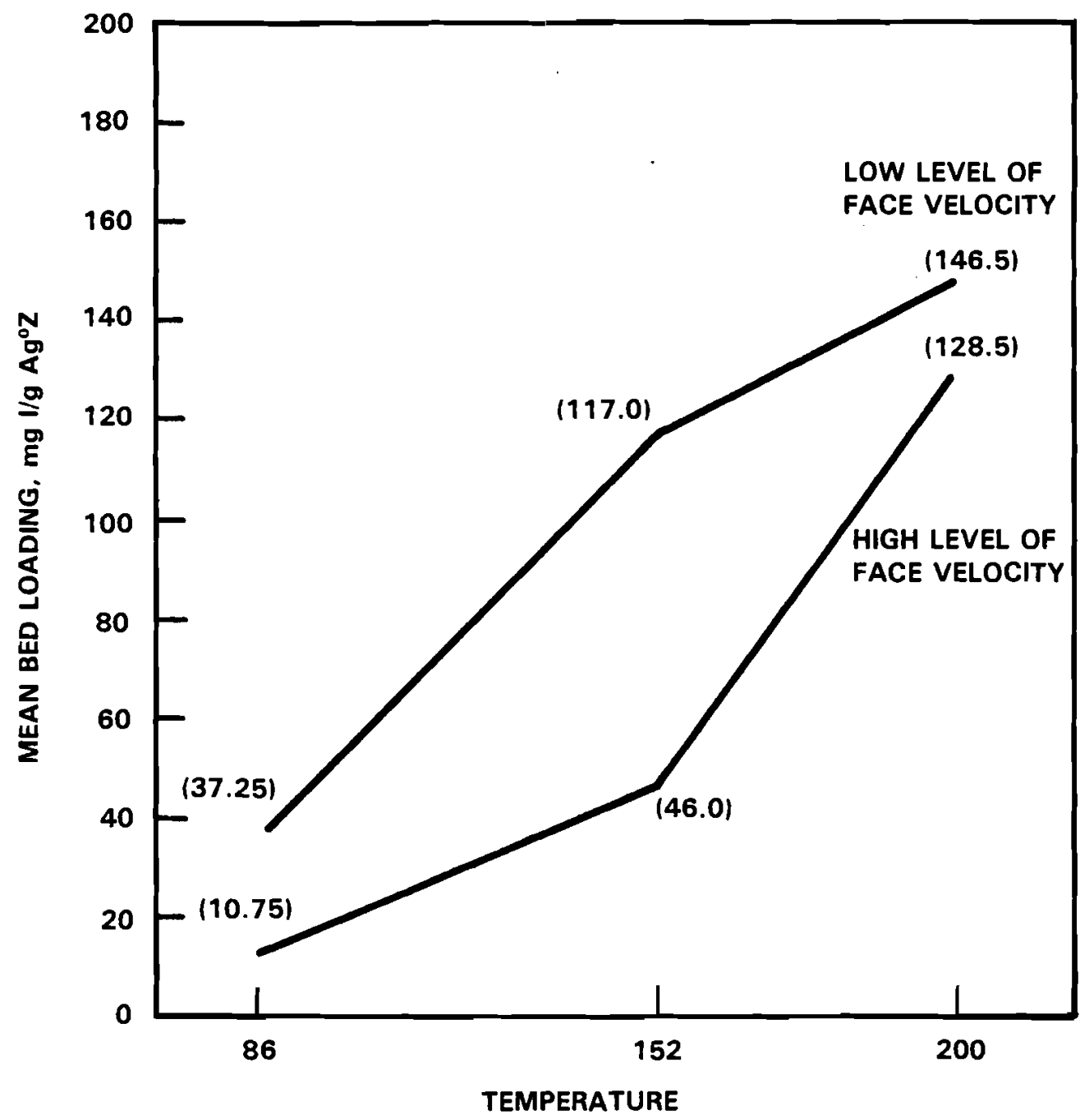

FIGURE 11. Phase 2 Analysis: The Effect of Temperature on $\mathrm{CH}_{3} \mathrm{I}$ Capture by $\mathrm{Ag}^{\circ} \mathrm{Z}$ at Face Velocities of 3.75 and $15.0 \mathrm{~m} / \mathrm{min}$ 


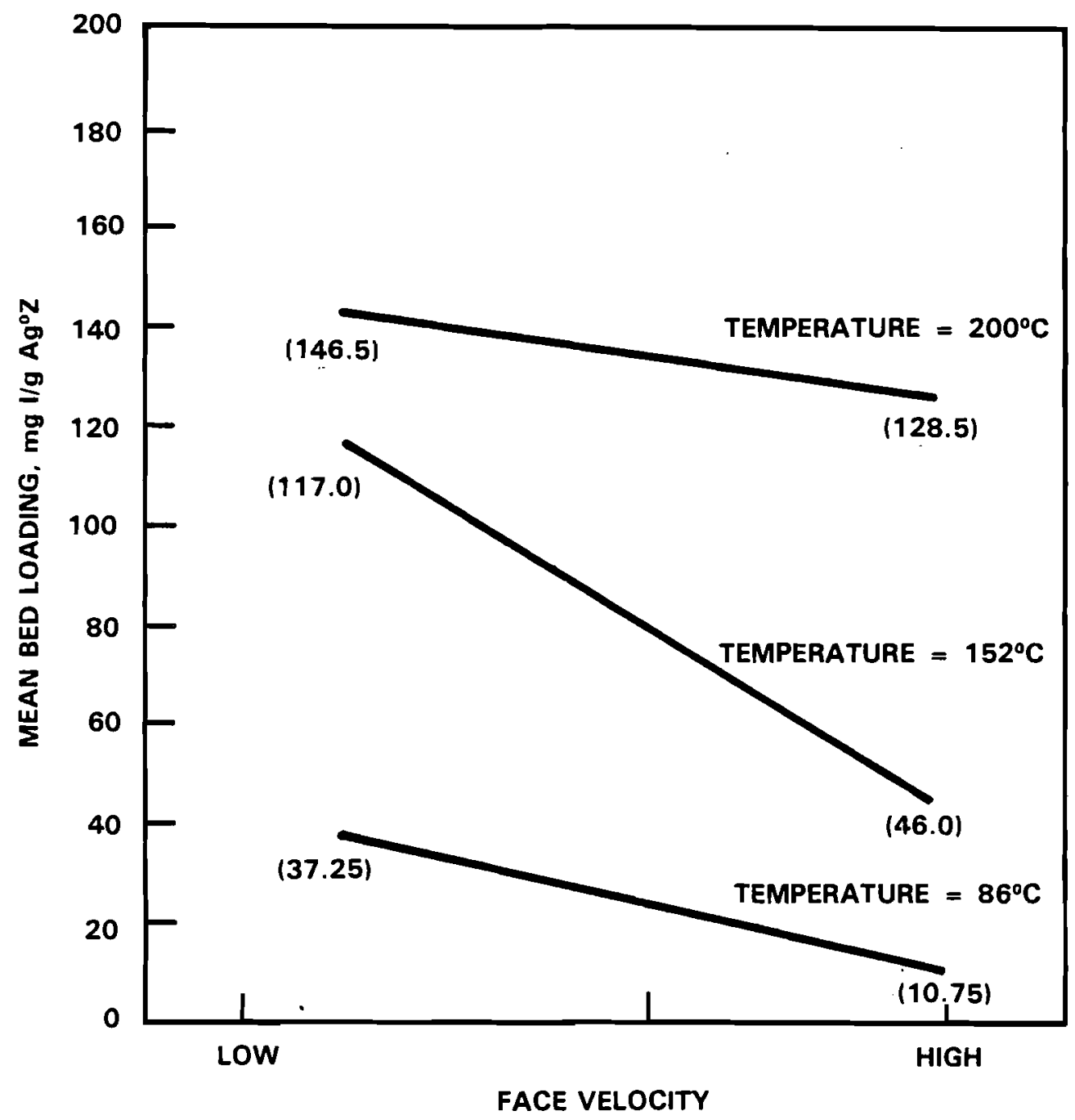

FIGURE 12. Phase 2 Analysis: The Effect of Face Velocity on $\mathrm{CH}_{3} \mathrm{I}$ Capture by $\mathrm{Ag}^{\circ} \mathrm{Z}$ at 86,152 , and $200^{\circ} \mathrm{C}$ 


\section{CONCLUSIONS AND RECOMMENDATIONS}

Our studies have shown the effectiveness of capturing $\mathrm{CH}_{3} \mathrm{I}$ with $\mathrm{AgZ}$ that has been reduced (hydrogen pretreated). By extrapolation, $\mathrm{Ag}^{\circ} \mathrm{Z}$ should be an effective trap for other organic iodides found in the POG. The efficiency of $\mathrm{CH}_{3} \mathrm{I}$ capture is dependent on various operational parameters and is affected by other gases in the POG of a nuclear reprocessing plant.

Maximum efficiency for the removal of $\mathrm{CH}_{3} \mathrm{I}$ from gas streams by $\mathrm{AgZ}$ is obtained by small particle size, low face velocity, absence of NO, presence of water in the gas stream, and elevation of the temperature from 150 to around $200^{\circ} \mathrm{C} . \mathrm{Ag}^{\circ} \mathrm{Z}$ is preferred over $\mathrm{AgZ}$, and for the 10-16 mesh particles, a bed of at least $15 \mathrm{~cm}$ deep is suggested.

Complex interactions exist between the parameters investigated here. A better understanding of these might be obtained with a set of experiments using a relatively shallow bed and by observing the kinetics of capture rather than total bed loading.

Additional studies are recommended to improve knowledge on the basic chemistry of the sorption reaction of $\mathrm{CH}_{3} \mathrm{I}$ and $\mathrm{I}_{2}$ by silver zeolites. 


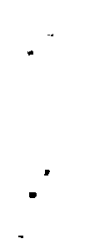




\section{REFERENCES}

Addison, W. E. and R. M. Barrer. 1955. "Sorption and Reactivity of Nitrous Oxide and Nitric Oxide in Crystalline and Amorphous Siliceous Sorbents." Chem. Society Journal 757 .

Barin, I. and 0. Knacke. 1973. Thermochemical Properties of Inorganic Substances. Springer-Verlag, New York.

Barin, I., 0. Knacke, and 0. Kubaschewski. 1977. Thermochemical Properties of Inorganic Substances: Supplement. Springer-Verlag, New York.

Breck, D. W. 1974. Zeolite Molecular Sieves, Structure, Chemistry, and Use. John Wiley \& Sons, New York.

Burger, L. L. and R. D. Scheele. 1981. "Iodine Fixation Studies at the Pacific Northwest Laboratory." In Management Modes for Iodine-129, W. Hebel and G. Cottone, eds. Harwood Academic Publishers, New York.

Burger, L. L. and R. D. Scheele. 1982. Recycle of Iodine-Loaded Silver Mordenite by Hydrogen Reduction. PNL-4490, Pacific Northwest Laboratory, Richland, Washington.

Chao, Chien-Chung, and J. H. Lunsford. 1971a. "Infrared Studies of the Disproportionation Reaction of Nitric Oxide on Y-Type Zeolites." JACS 93(1):71.

Chao, Chien-Chung, and J. H. Lunsford. 1971b. "Adsorption of Nitric Oxide on Y-Type Zeolites: A Low-Temperature Infrared Study." JACS 93(25):6794.

Coleman, J. E. and R. D. Scheele. 1981. "Scanning Electron Microscopy Studies." In "Iodine Fixation," Nuclear Waste Management Quarterly Progress Report, April through June 1981. PNL-3000-10, T. D. Chikalla and J. A. Powe11, eds. Pacific Northwest Laboratory, Richland, Washington.

Daniel, J. L., J.E. Coleman, and R. D. Scheele. 1980. "Scanning Electron Microscopy Studies." In "Iodine Fixation," Nuclear Waste Management Quarterly Report, July through September 1980. PNL-3000-7, T. D. Chikalla and J. A. Powe11, eds., Pacific Northwest Laboratory, Richland, Washington.

Donner, C. and T. Tamberg. 1971. "Zur Abscheidung von Methyl und Athyljodid an Silverzeolithen." P. 28, Atomwirtschaft, Jan 1971.

Donner, C. and T. Tamberg. 1972. "Zur Abscheidung Von Methyljodid an Silverzeol ithen." Z. Naturforsch 27:1323-1328.

Glasstone, S. and G. Bel1. 1946. Textbook of Physical Chemistry. 2nd ed. D. Van Nostrand Company, Inc., New York.

Hirschfelder, J. 0., C. F. Curtiss, and R. B. Bird. 1954. Molecular Theory of Gases and Liquids. John Wiley \& Sons, New York. 
Jubin, R. T. 1982. "Organic Iodine Removal from Simulated Dissolver Offgas Systems Using Partially Exchanged Silver Mordenite." In Proceedings of the 17 th Air Cleaning Conference, CONF-820833-12, National Technical Information Service, Springfield, Virginia.

Jubin, R. T. 1980. "Organic Iodine Removal from Simulated Dissolver Off-Gas Streams Using Silver-Exchanged Mordenite." In Proceedings of the 16th Air Cleaning Conference, CONF-801038, National Technical Information Service, Springfield, Virginia.

Kasai, P. H. and R. J. Bishop, Jr. 1972. "Electron Spin Resonance Study of Nitric 0xide Adsorption on Linde Type X Zeolites." JACS 94(16):5560.

Kennard, E. H. 1938. Kinetic Theory of Gases. McGraw-Hi11, New York.

Latimer, W. M. 1956. Oxidation Potentials. 2nd ed. Prentice-Hall, Inc., Englewood Cliffs, New Jersey.

Meier, W. T. and D. H. 0lson. 1971. "Zeolite Frameworks." In Molecular Sieve Zeolites, ed. R. F. Gould. Advances in Chemistry Series 101, American Chemical Society, Washington, D.C.

Minachev, K. H. and Y. I. Isakov. 1976. "Catalytic Properties of MetalContaining Zeolites." In Zeolite Chemistry and Catalysis, ed. J. A. Rabo, pp. 552-611. ACS Monograph No. 171. American Chemical Society, Washington, D.C.

Murphy, L. P., B. A. Staples, and T. R. Thomas. 1977. The Development of $\mathrm{Ag}^{\circ} \mathrm{Z}$ for Bulk 129 I Removal from Nuclear Fuel Reprocessing $P$ Tants and PbX for I29 I Storage. ICP-1135, Idaho National Engineering Laboratory, Idaho Fal1s, Idaho.

Pietrzak, T. M. and D. E. Wood. 1970. "EPR Study of the Hindered Motion of $\mathrm{NO}_{2}$ and $\mathrm{ClO}_{2}$ Adsorbed in Synthetic Zeolites." J. Chem. Phys. 53(6):2454.

Scheele, R. D., 1981. "Silver Sorbent Characterization." In "Iodine-129 Fixation," Nuclear Waste Management Quarterly Progress Report, July-September 1981. PNL-3000-11, T. D. Chikalla and J. A. Powell, eds., Pacific Northwest Laboratory, Richland, Washington.

Scheele, R. D. and L. L. Burger. 1981. "Characterization Studies of IodineLoaded Silver Zeolites," PNL-SA-9510. Paper presented at the 182nd National Meeting of the American Chemical Society, August 23-28, 1981, New York.

Scheele, R. D., C. L. Matsuzaki, and L. L. Burger. 1981. "Iodine Recovery Studies." In "Iodine-129 Fixation," Nuclear Waste Management Quarterly Progress Report, April through June 1981. PNL-3000-10, T. D. Chikalla and J. A. Powell, eds. Pacific Northwest Laboratory, Richland, Washington.

Snedecor, G. W., and W. G. Cochran. 1980. Statistical Methods. 7th ed. Iowa State University Press, Ames, Iowa. 
Strachan, D. M. 1978. Analysis of the Dissolver Silver Reactors from Hanford's Purex Plant. RHO-ST-2, Rockwell Hanford Operations, Richland, Washington.

Thomas, T. R., L. P. Murphy, B. A. Staples, and J. T. Nichols. 1977 . Airborne Elemental Iodine Loading Capacities of Metal Zeolites and a Method for Recycling Silver Zeolite. ICP-1119, Idaho National Engineering Laboratory, Idaho Falls, Idaho.

Wiemers, K. D. 1978. "Iodine Recovery Studies," Nuclear Waste Management Quarterly Progress Report, October through December 1978. PNL-2378-4, A. M. Platt and J. A. Powell, eds., Pacific Northwest Laboratory, Richland, Washington.

Wiemers, K. D. and R. D. Scheele. 1979. "Iodine Recovery." In "Carbon-14 and Iodine-129 Fixation," Nuclear Waste Management Quarterly Progress Report, April through June 1979. PNL-3000-2, A. M. Platt and J. A. Powe11, eds., Pacific Northwest Laboratory, Richland, Washington. 

APPENDIX A

$\mathrm{CH}_{3} \mathrm{I}$ LOADING CURVES 



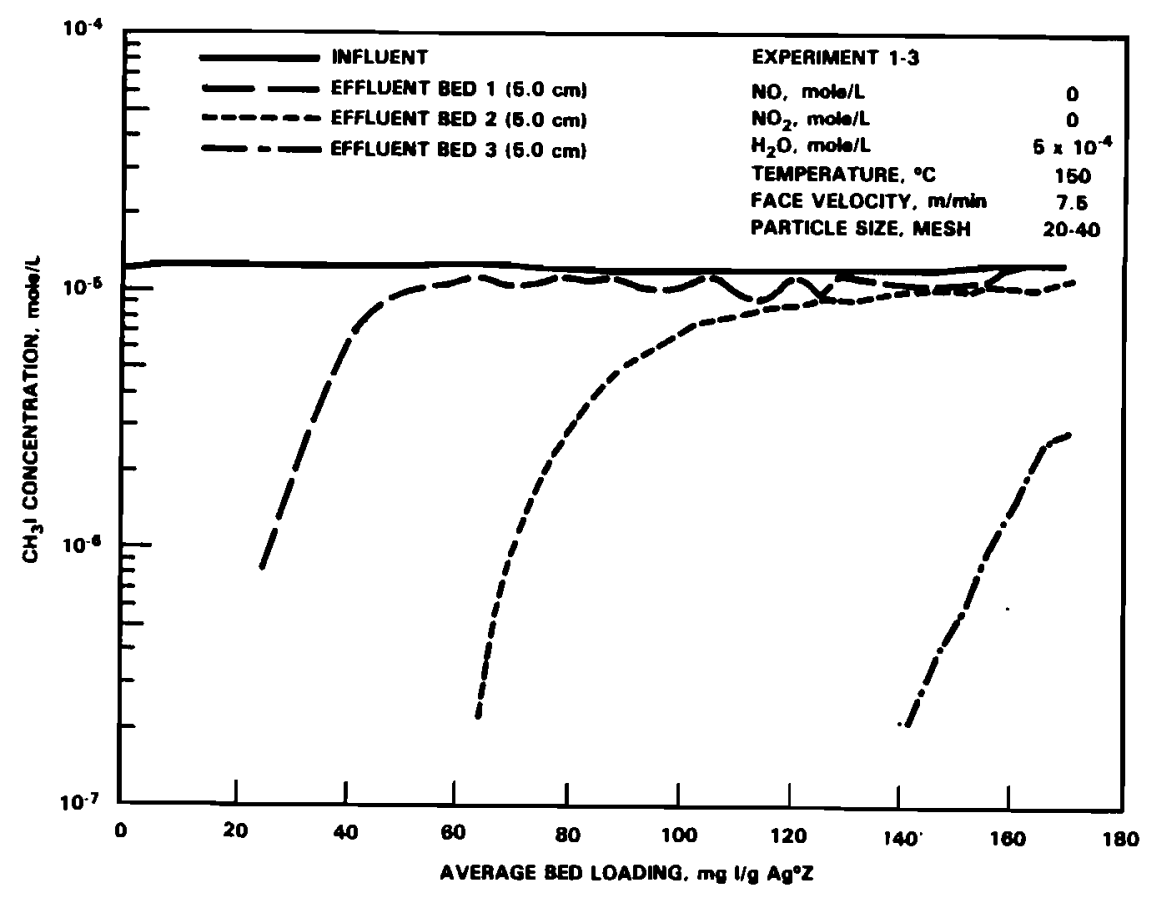

FIGURE A.1. $\quad \mathrm{CH}_{3} \mathrm{I}$ Capture by $\mathrm{Ag}^{\circ} \mathrm{Z}$, Experiment 1-3

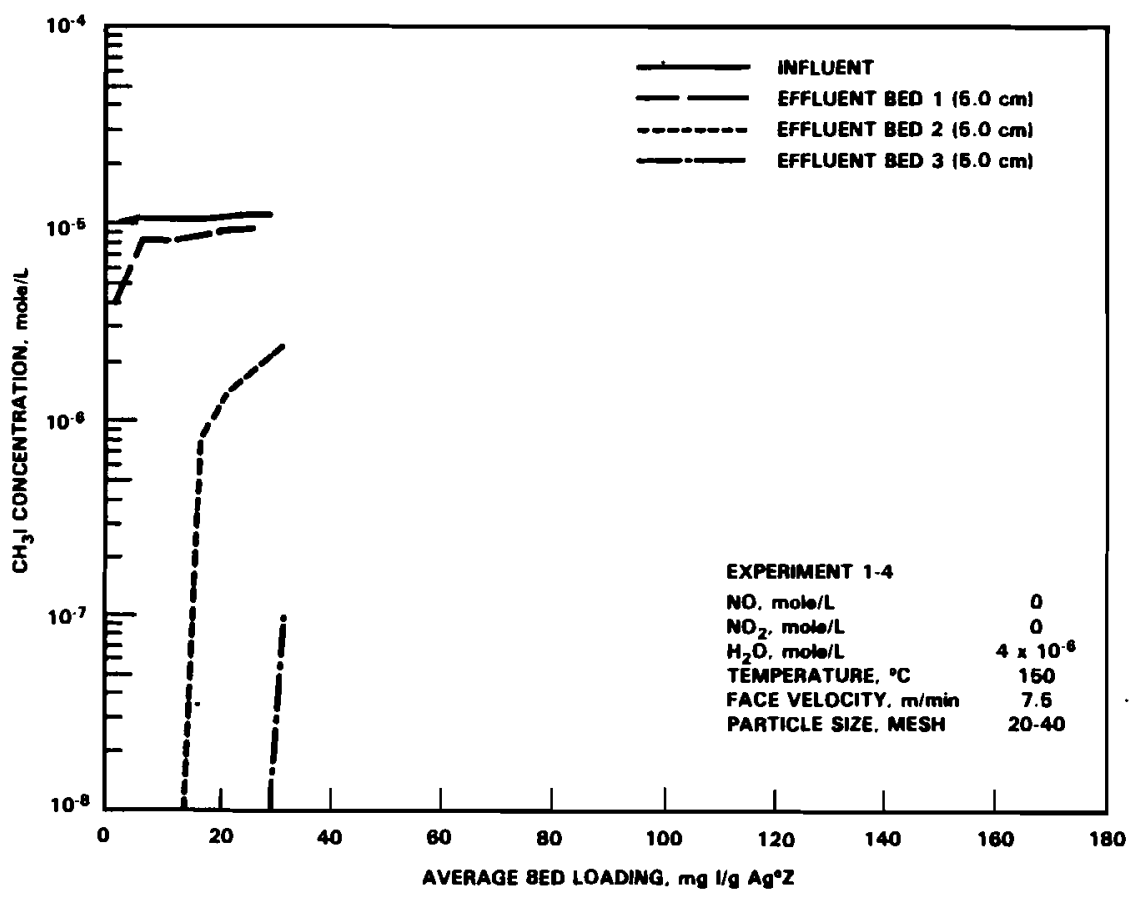

FIGURE A.2. $\mathrm{CH}_{3} \mathrm{I}$ Capture by $\mathrm{Ag}^{\circ} \mathrm{Z}$, Experiment $1-4$ 


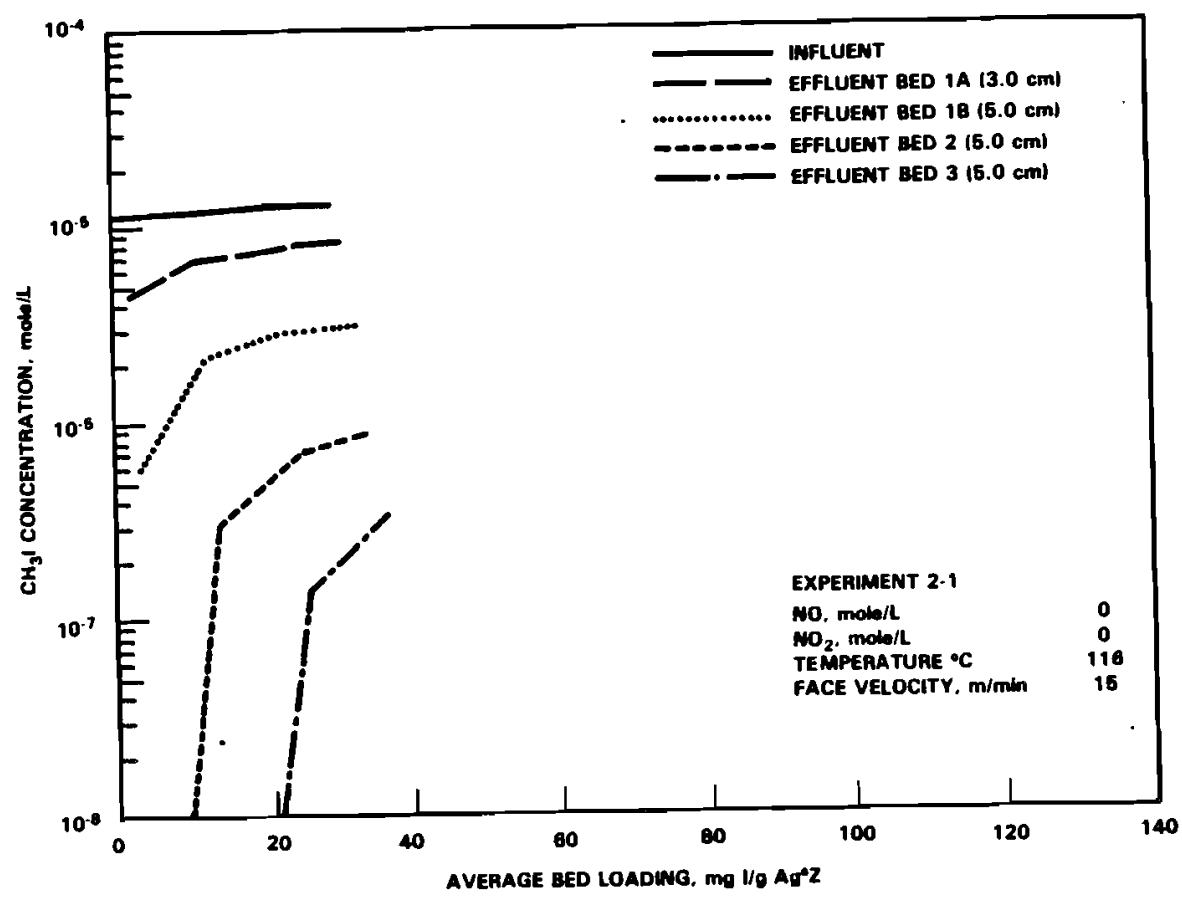

FIGURE A.3. $\quad \mathrm{CH}_{3} \mathrm{I}$ Capture by $\mathrm{Ag}^{\circ} \mathrm{Z}$, Experiment 2-1

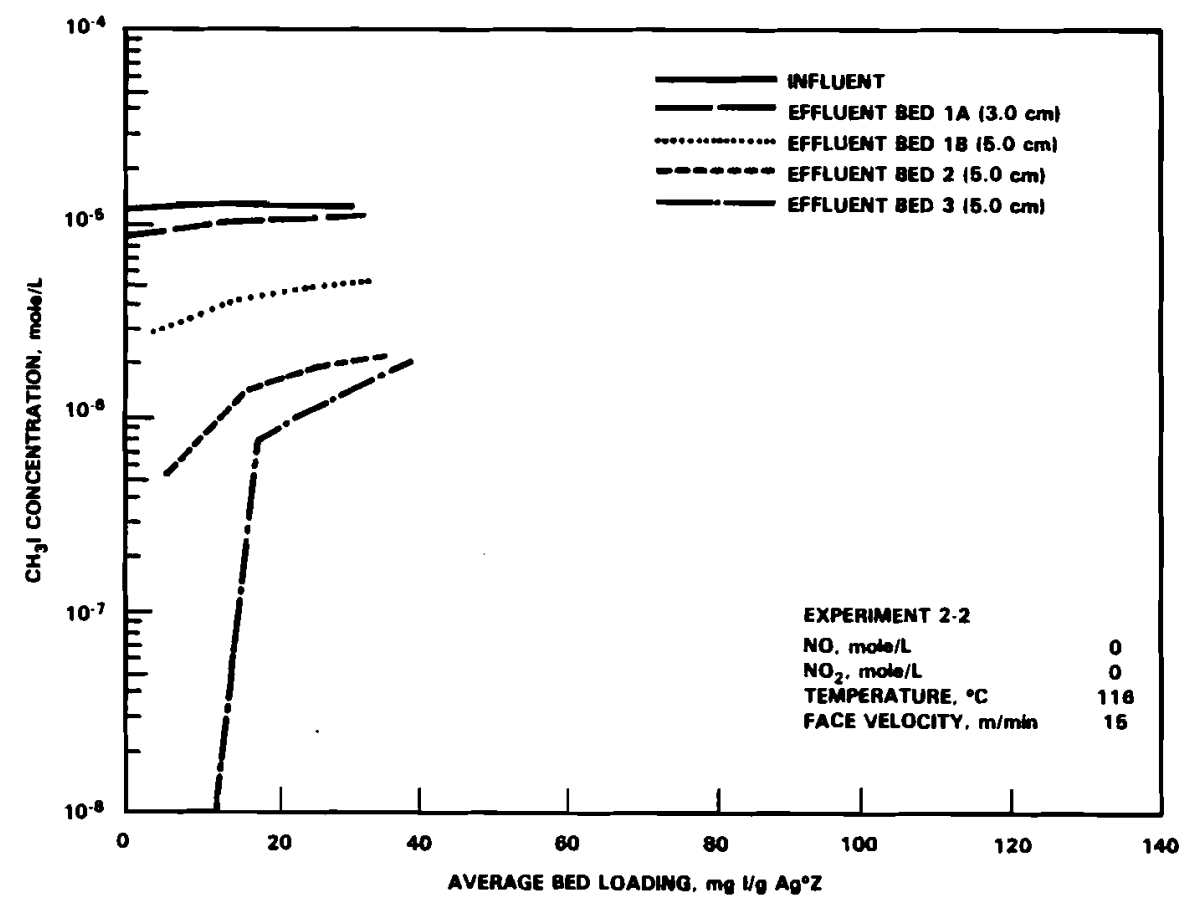

FIGURE A.4. $\quad \mathrm{CH}_{3} \mathrm{I}$ Capture by $\mathrm{Ag}^{\circ} \mathrm{Z}$, Experiment 2-2 


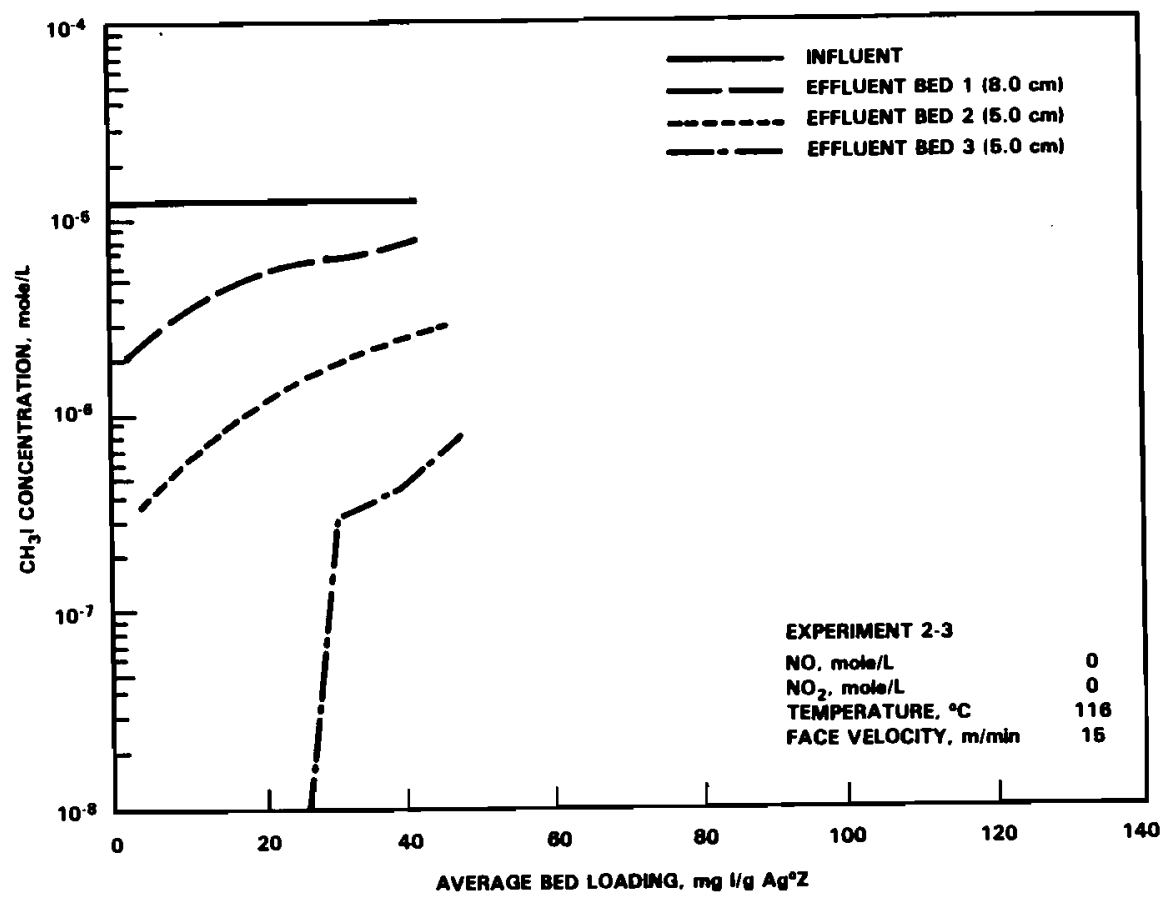

FIGURE A.5. $\quad \mathrm{CH}_{3}$ I Capture by $\mathrm{Ag}^{\circ} \mathrm{Z}$, Experiment 2-3

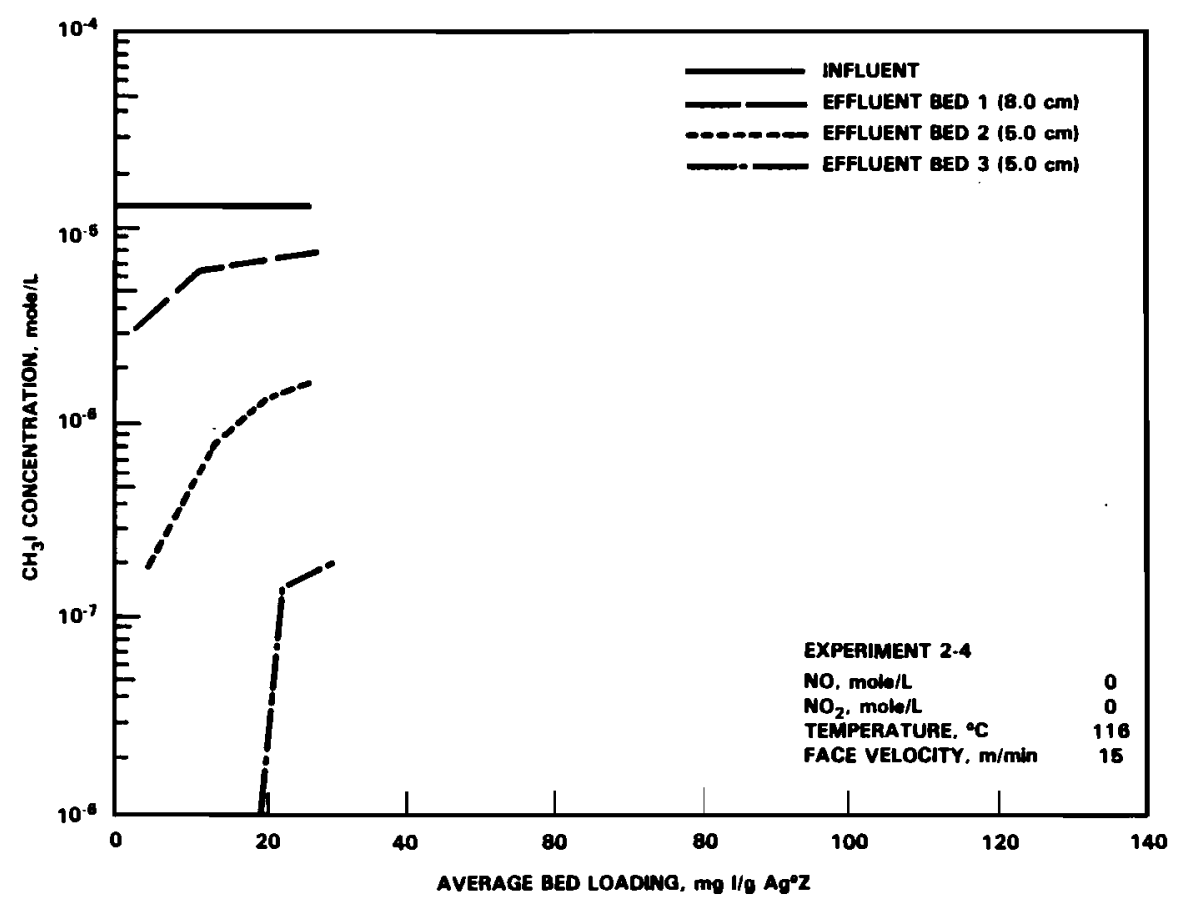

FIGURE A.6. $\quad \mathrm{CH}_{3} \mathrm{I}$ Capture by $\mathrm{Ag}^{\circ} \mathrm{Z}$, Experiment 2-4 


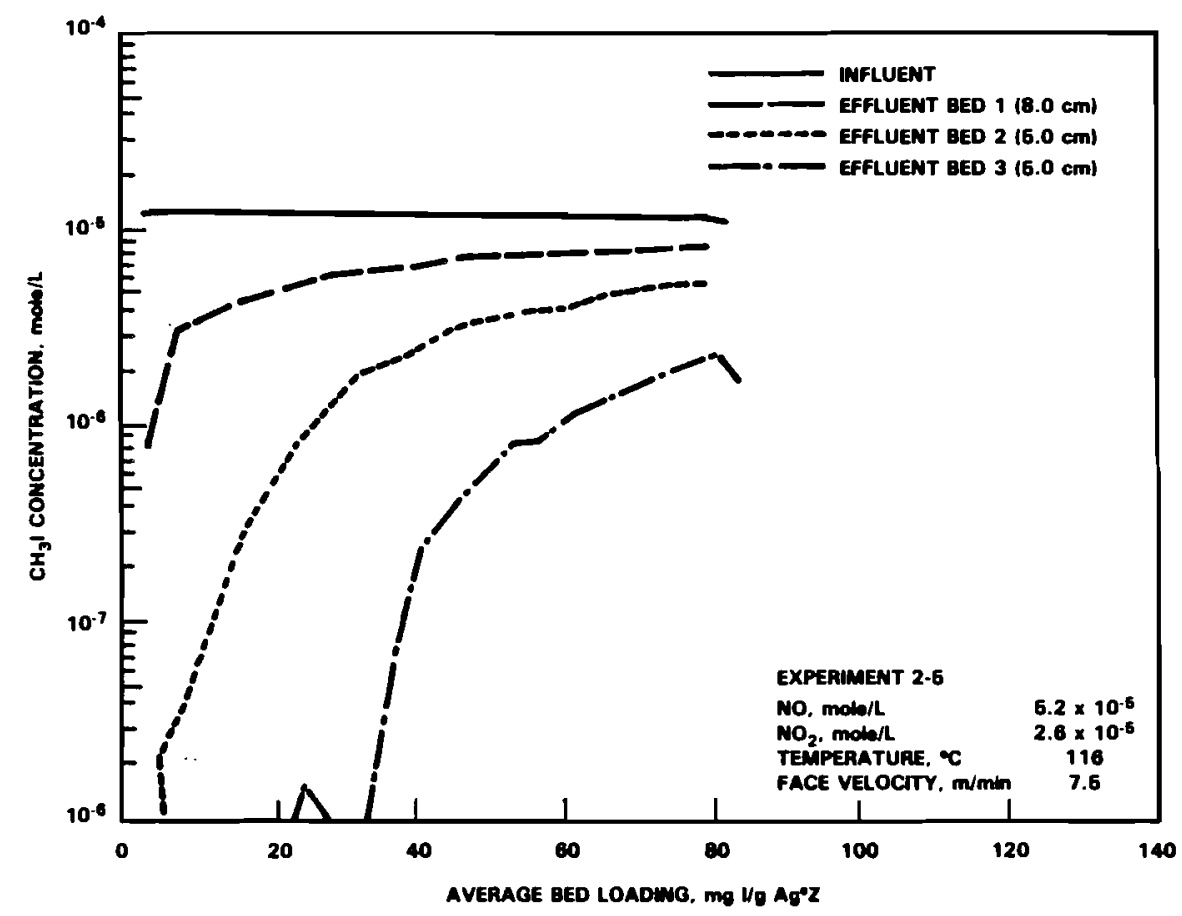

FIGURE A.7. $\mathrm{CH}_{3}$ I Capture by $\mathrm{Ag}^{\circ} \mathrm{Z}$, Experiment 2-5

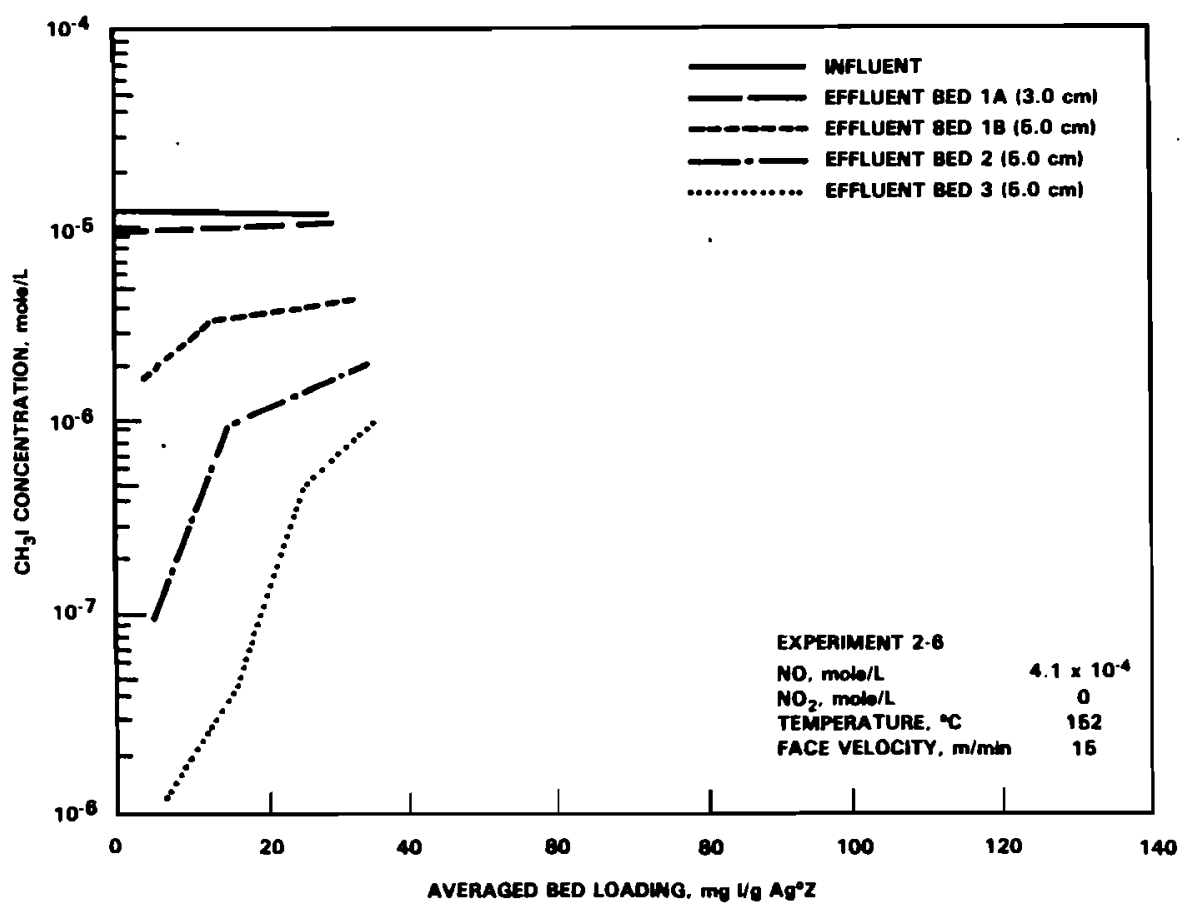

FIGURE A.8. $\quad \mathrm{CH}_{3}$ I Capture by $\mathrm{Ag}^{\circ} \mathrm{Z}$, Experiment 2-6 


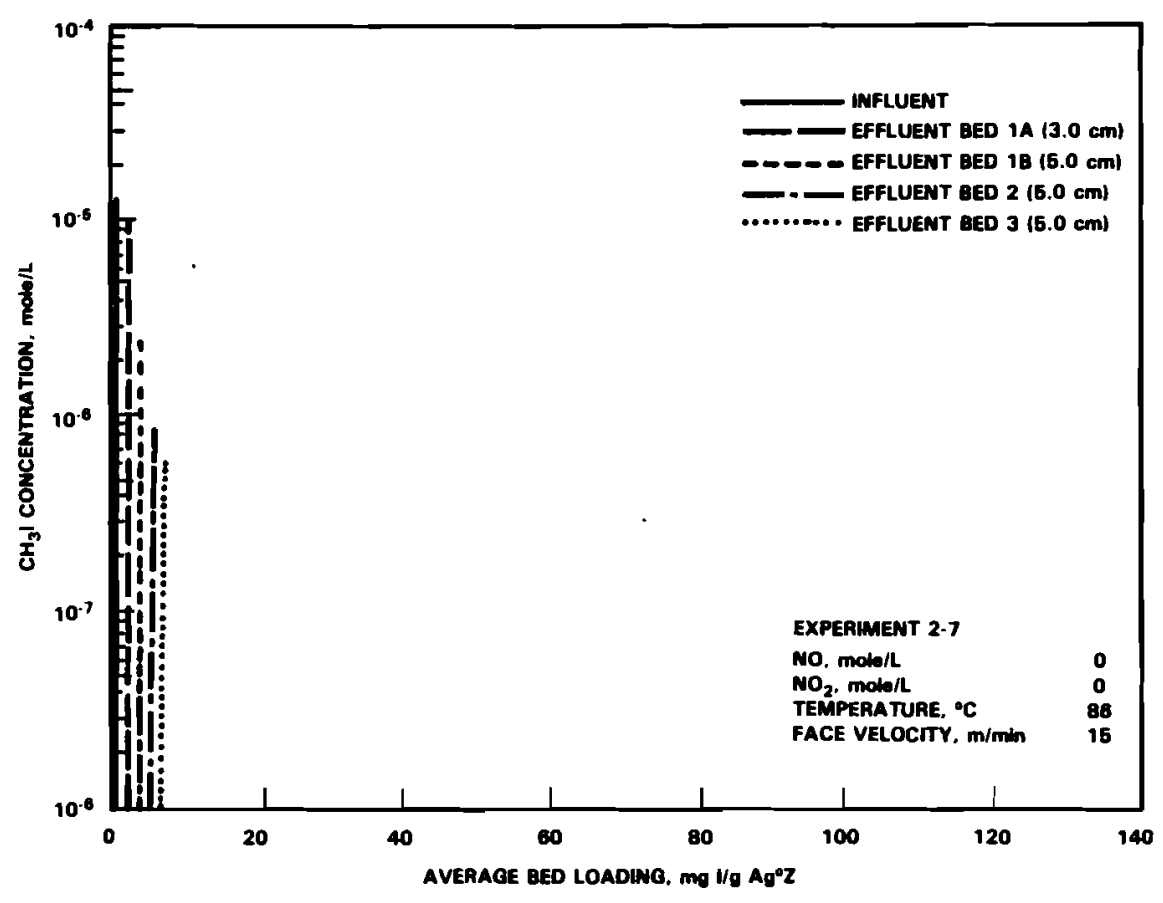

FIGURE A.9. $\quad \mathrm{CH}_{3} \mathrm{I}$ Capture by $\mathrm{Ag}^{\circ} \mathrm{Z}$, Experiment 2-7

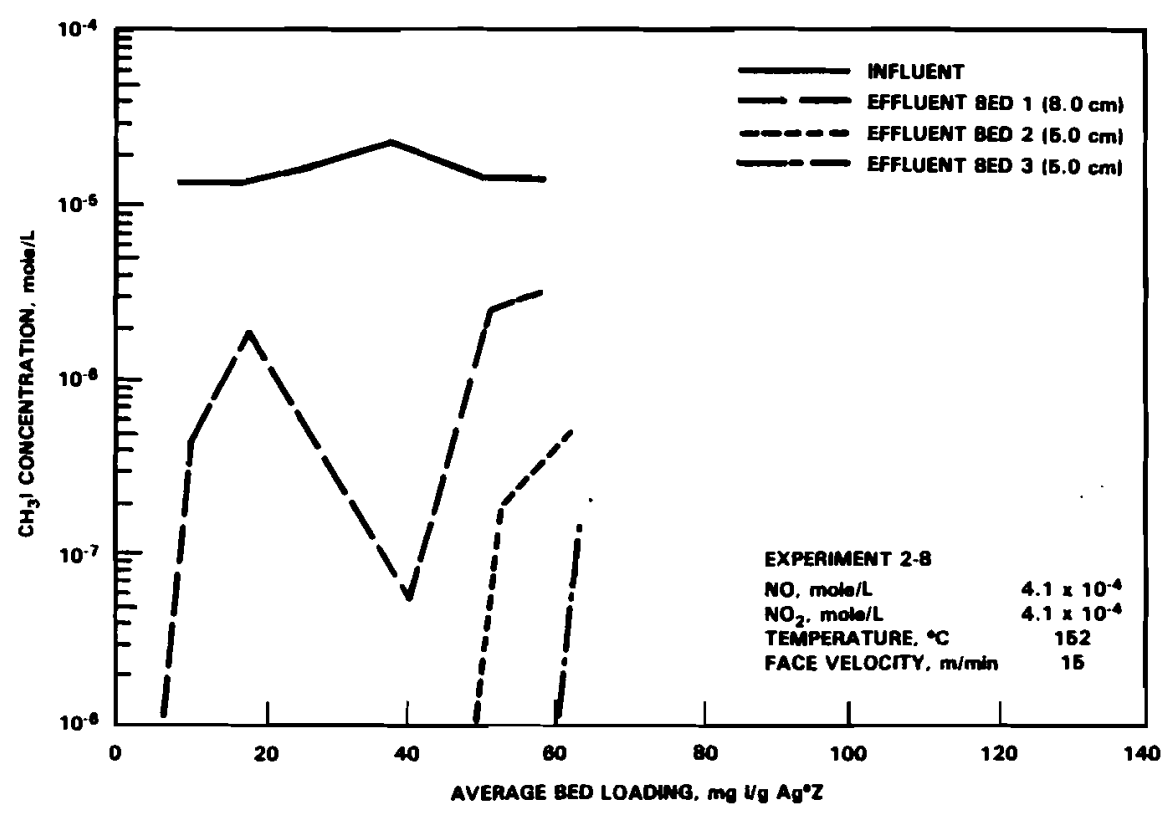

FIGURE A.10. $\mathrm{CH}_{3} \mathrm{I}$ Capture by $\mathrm{Ag}^{\circ} \mathrm{Z}$, Experiment 2-8 


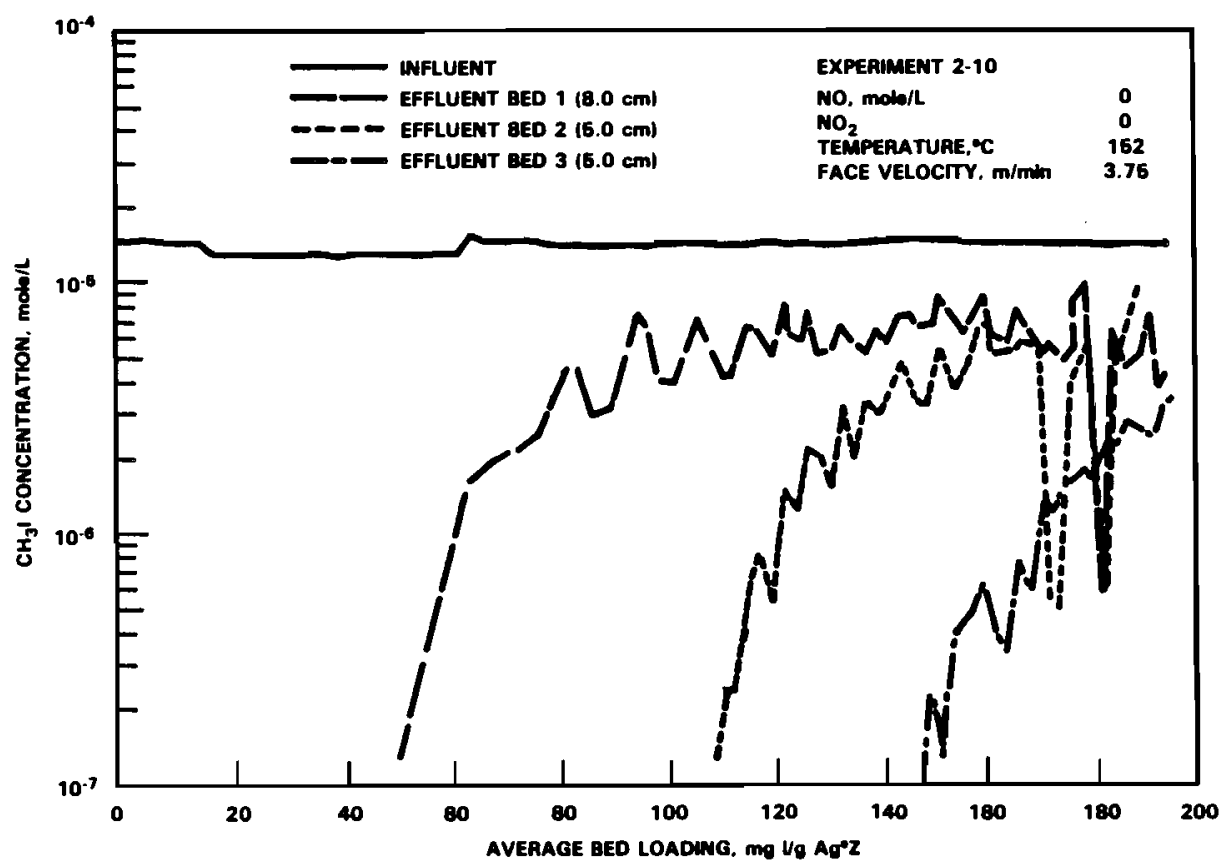

FIGURE A.11 $-\mathrm{CH}_{3}$ I Capture by $\mathrm{Ag}^{\circ} \mathrm{Z}$, Experiment 2-10

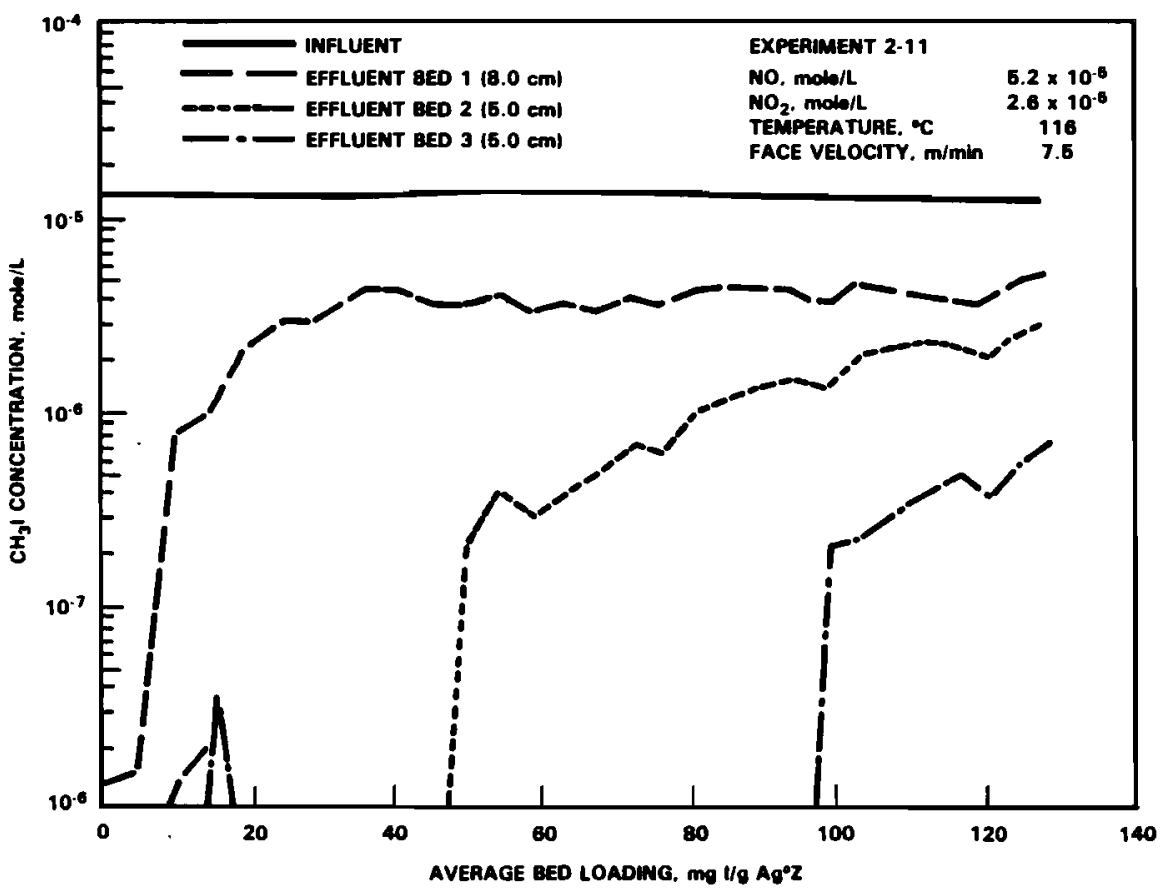

FIGURE A.12. $\mathrm{CH}_{3} \mathrm{I}$ Capture by $\mathrm{Ag}^{\circ} \mathrm{Z}$, Experiment 2-11 


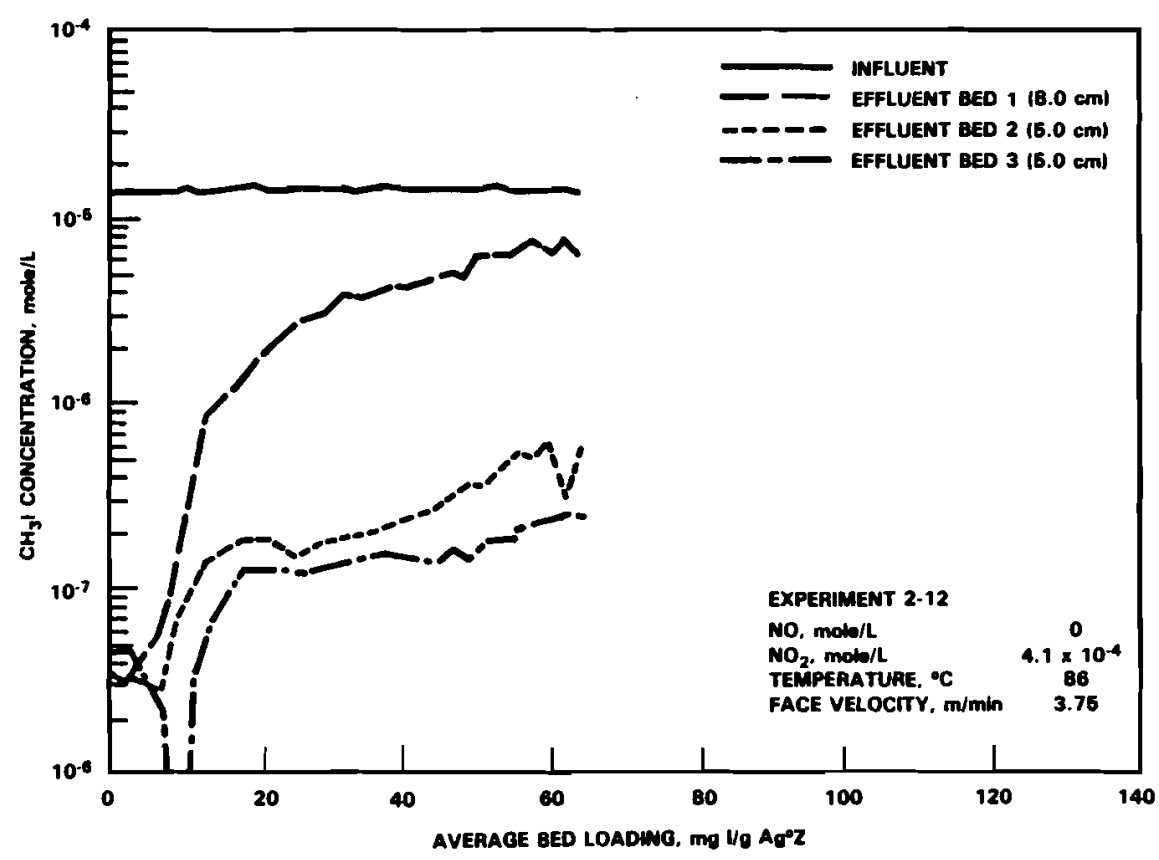

FIGURE A.13. $\mathrm{CH}_{3}$ I Capture by $\mathrm{Ag}^{\circ} \mathrm{Z}$, Experiment 2-12

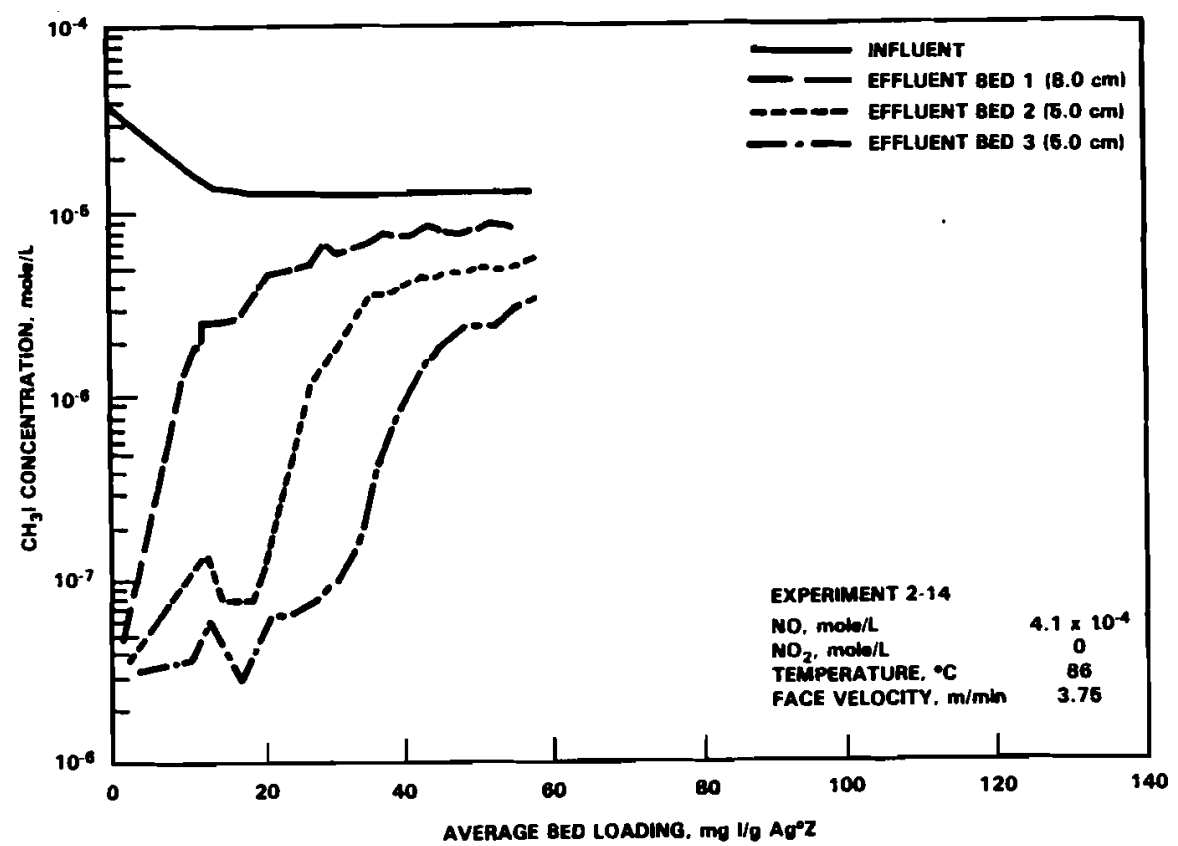

FIGURE A.14. $\mathrm{CH}_{3} \mathrm{I}$ Capture by $\mathrm{Ag}^{\circ} \mathrm{Z}$, Experiment 2-14 


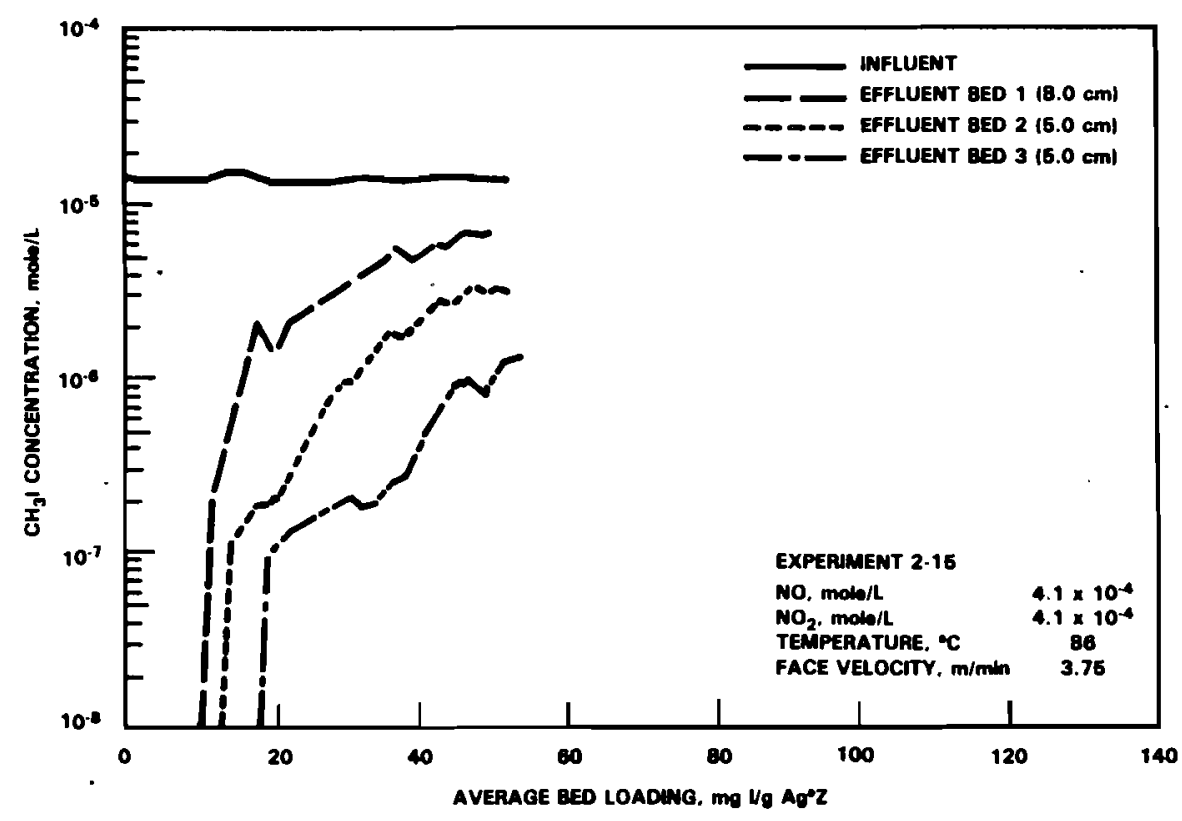

FIGURE A.15. $\mathrm{CH}_{3} \mathrm{I}$ Capture by $\mathrm{Ag}^{\circ} \mathrm{Z}$, Experiment 2-15

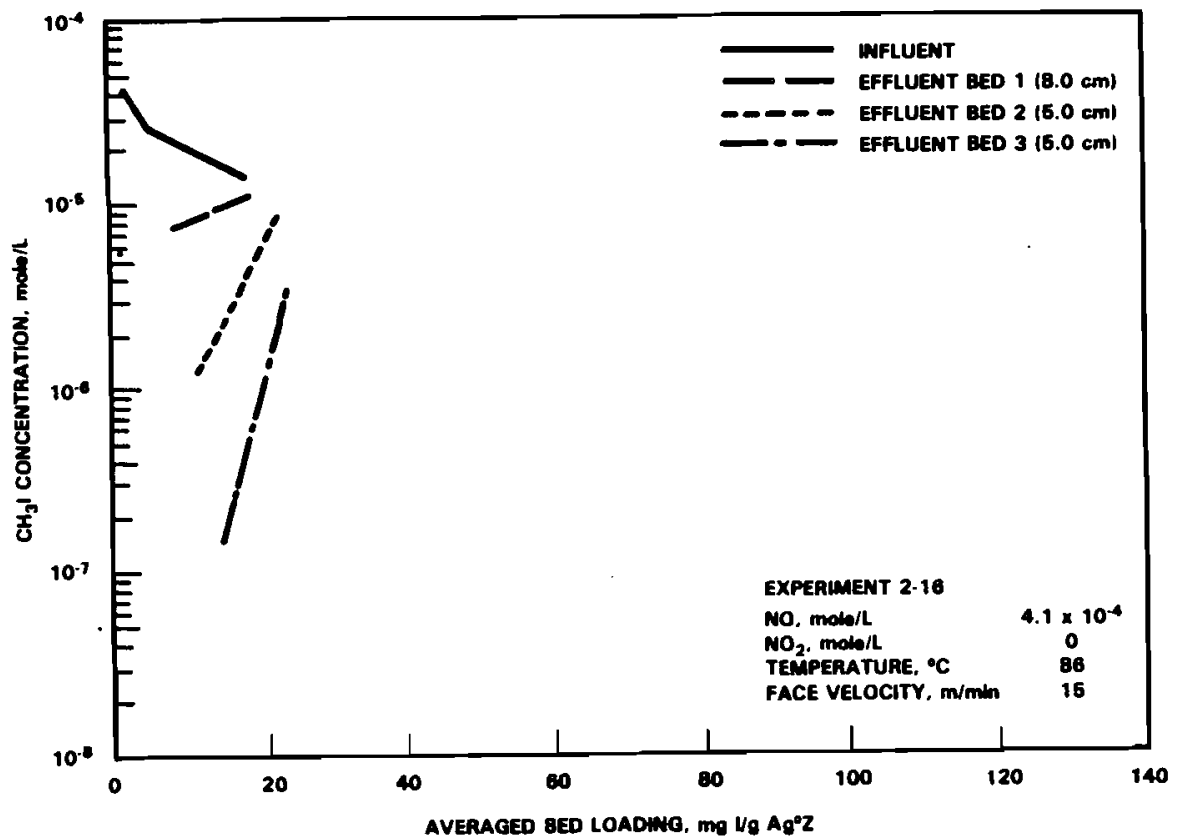

FIGURE A.16. $\mathrm{CH}_{3}$ I Capture by $\mathrm{Ag}^{\circ} \mathrm{Z}$, Experiment 2-16 


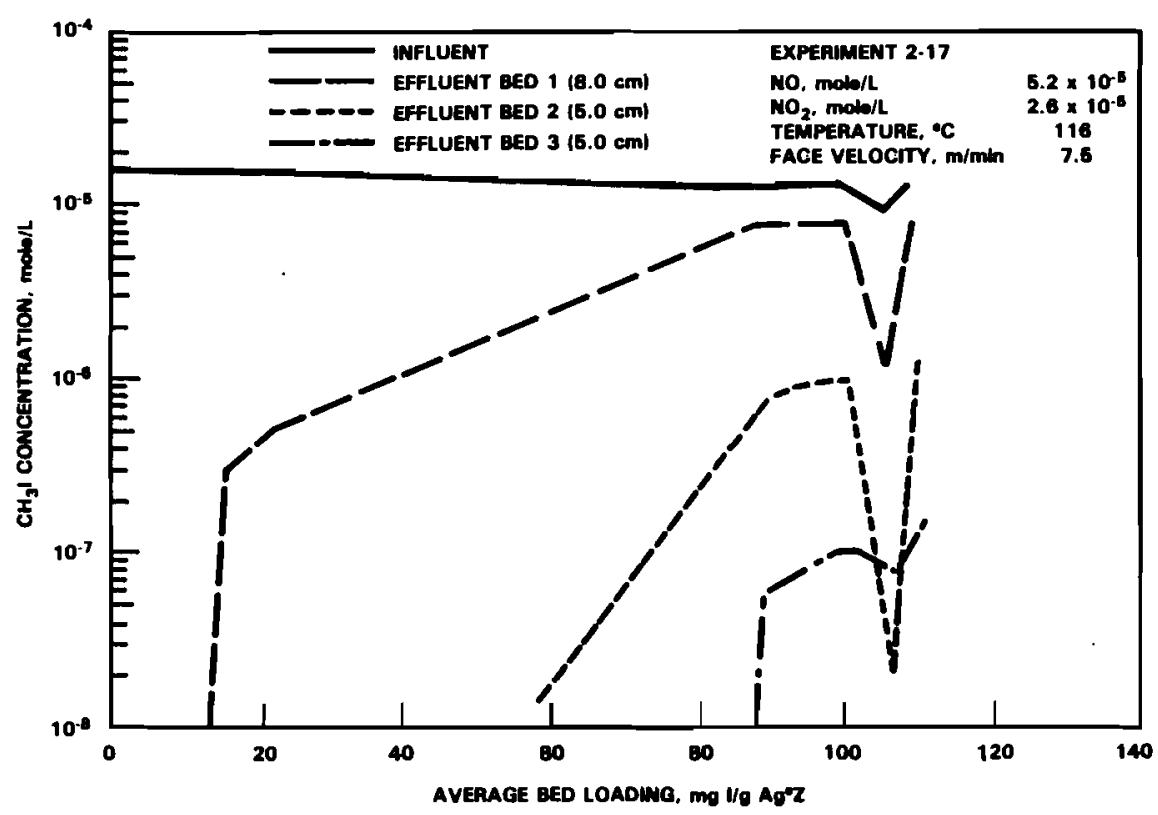

FIGURE A.17. $\mathrm{CH}_{3} \mathrm{I}$ Capture by $\mathrm{Ag}^{\circ} \mathrm{Z}$, Experiment 2-17

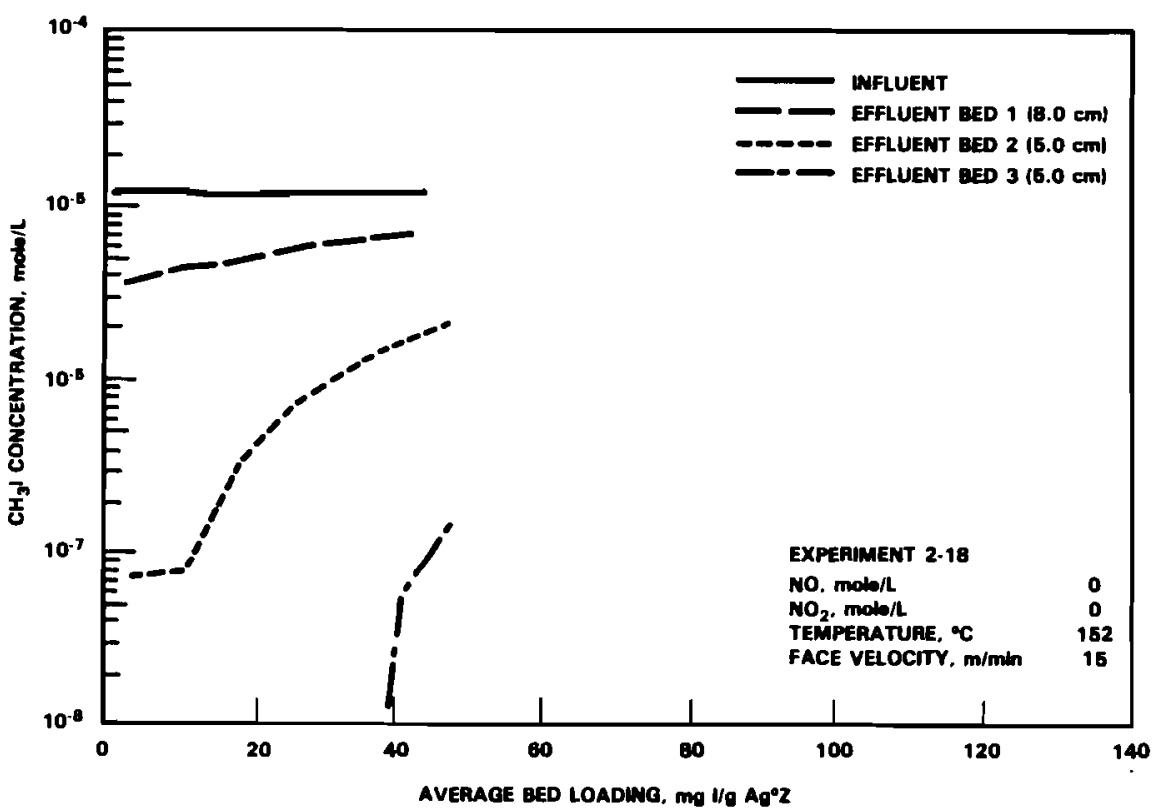

FIGURE A.18. $\mathrm{CH}_{3}$ I Capture by $\mathrm{Ag}^{\circ} \mathrm{Z}$, Experiment 2-18 


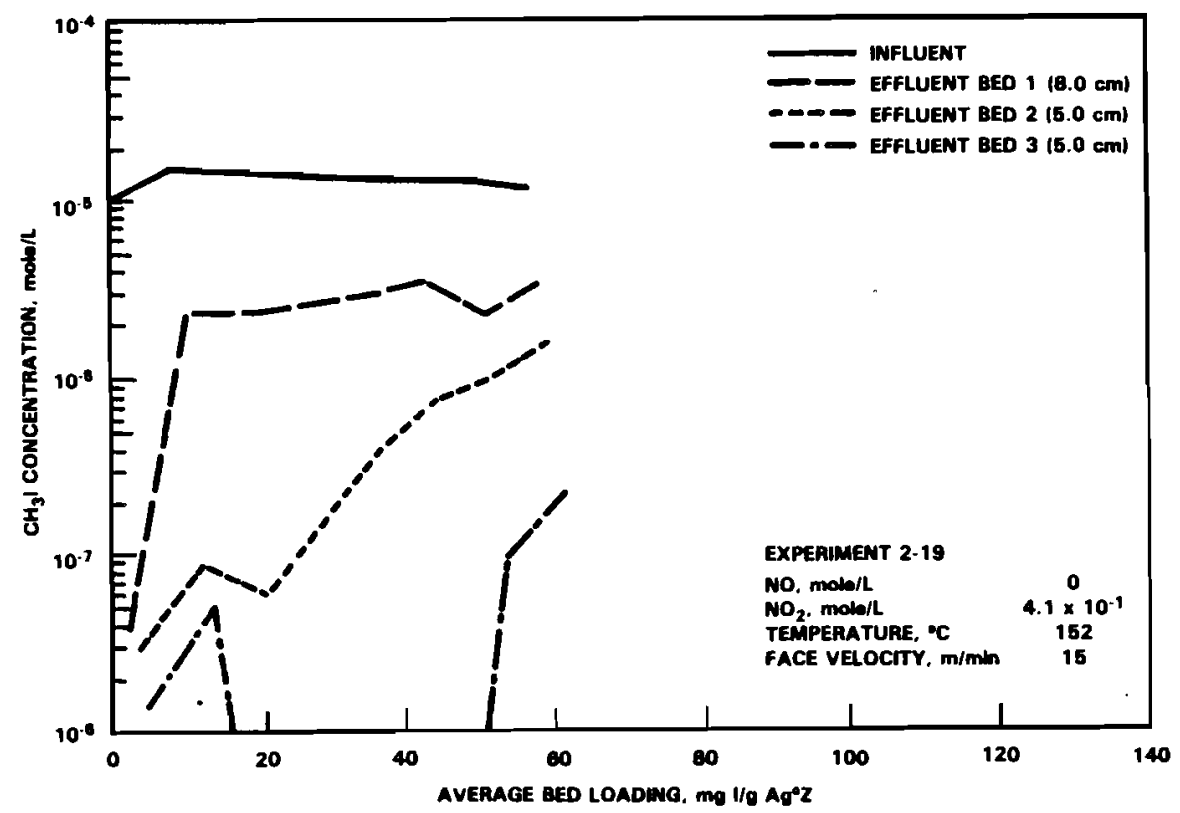

FIGURE A.19 $\quad \mathrm{CH}_{3} \mathrm{I}$ Capture by $\mathrm{Ag}^{\circ} \mathrm{Z}$, Experiment 2-19

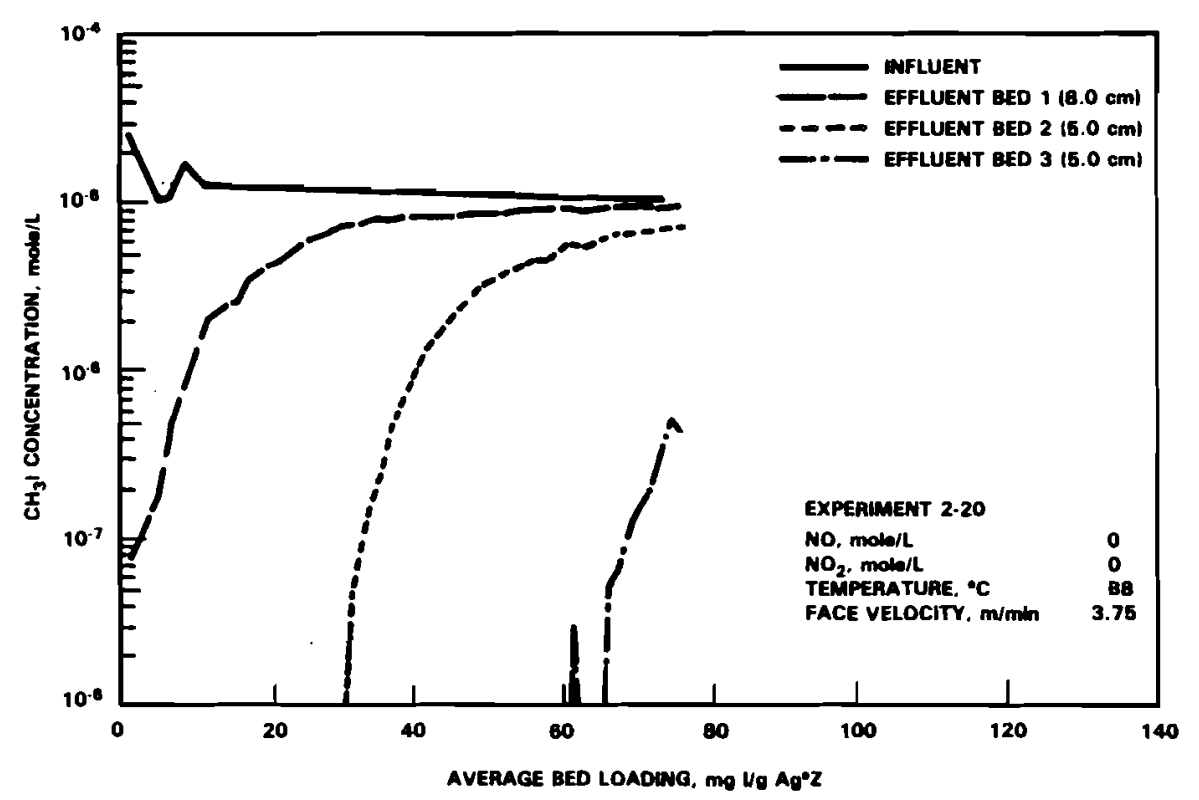

FIGURE A.20. $\mathrm{CH}_{3} \mathrm{I}$ Capture by $\mathrm{Ag}^{\circ} \mathrm{Z}$, Experiment 2-20 


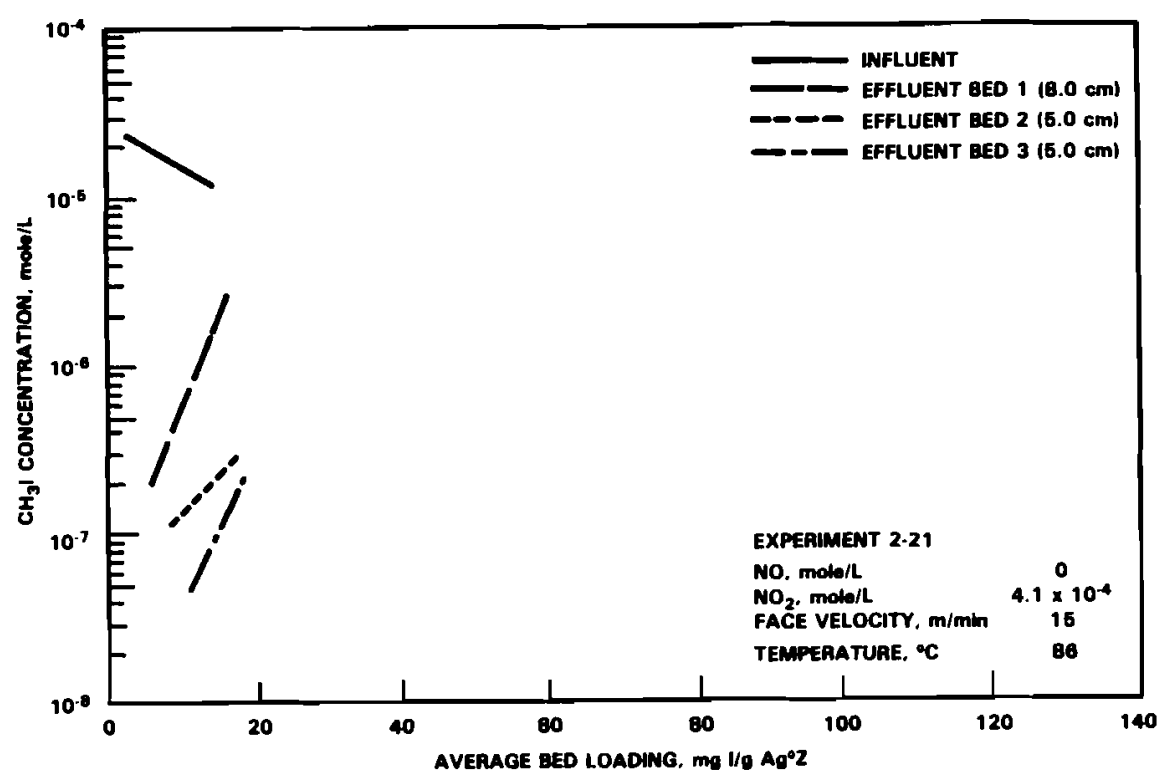

FIGURE A.21 $\quad \mathrm{CH}_{3} \mathrm{I}$ Capture by $\mathrm{Ag}^{\circ} \mathrm{Z}$, Experiment 2-21

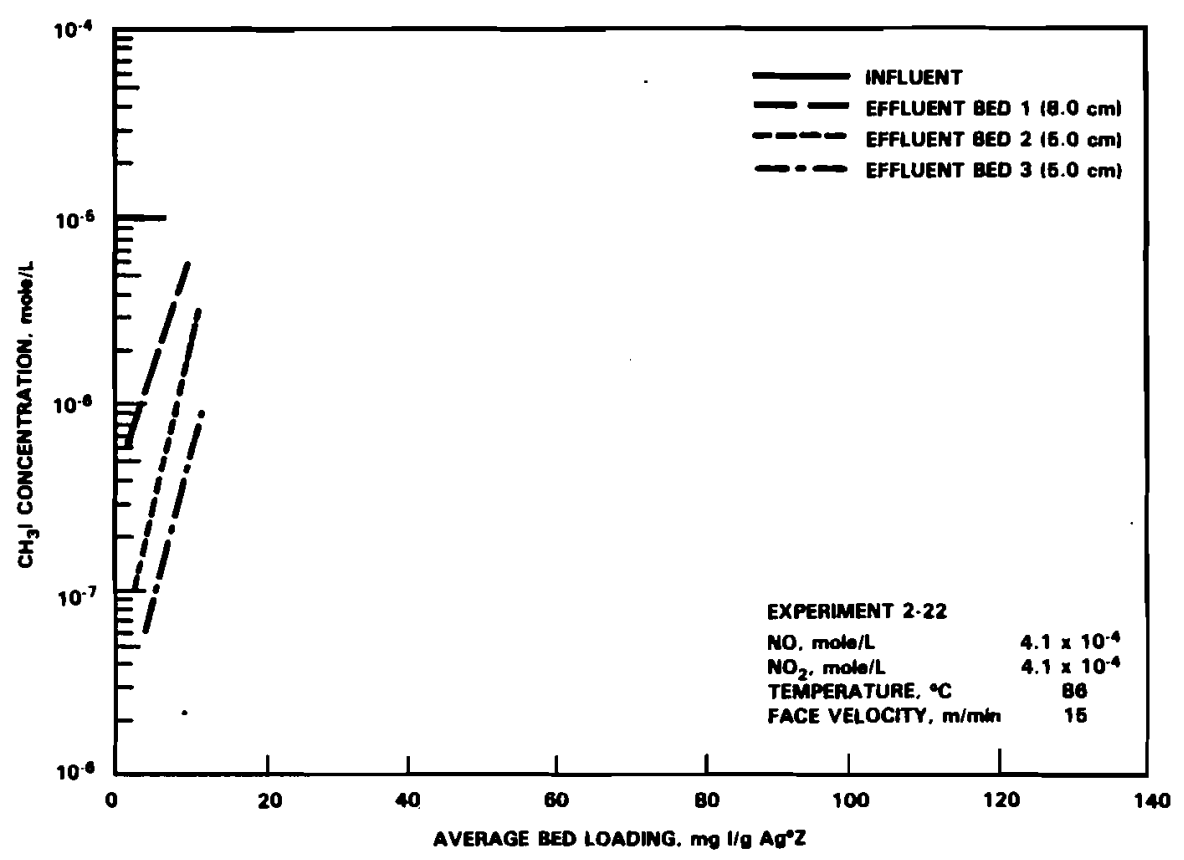

FIGURE A.22. $\mathrm{CH}_{3} \mathrm{I}$ Capture by $\mathrm{Ag}^{\circ} \mathrm{Z}$, Experiment 2-22 


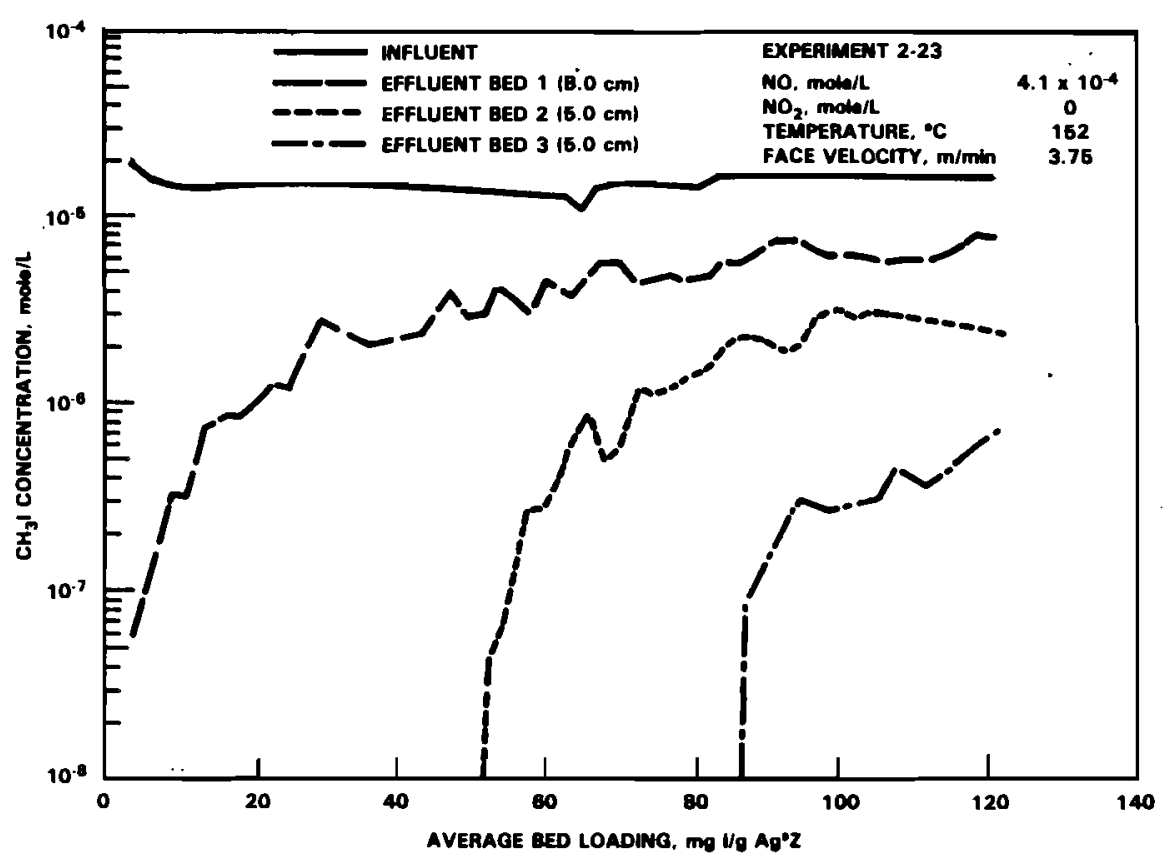

FIGURE A.23. $\mathrm{CH}_{3} \mathrm{I}$ Capture by $\mathrm{Ag}^{\circ} \mathrm{Z}$, Experiment 2-23

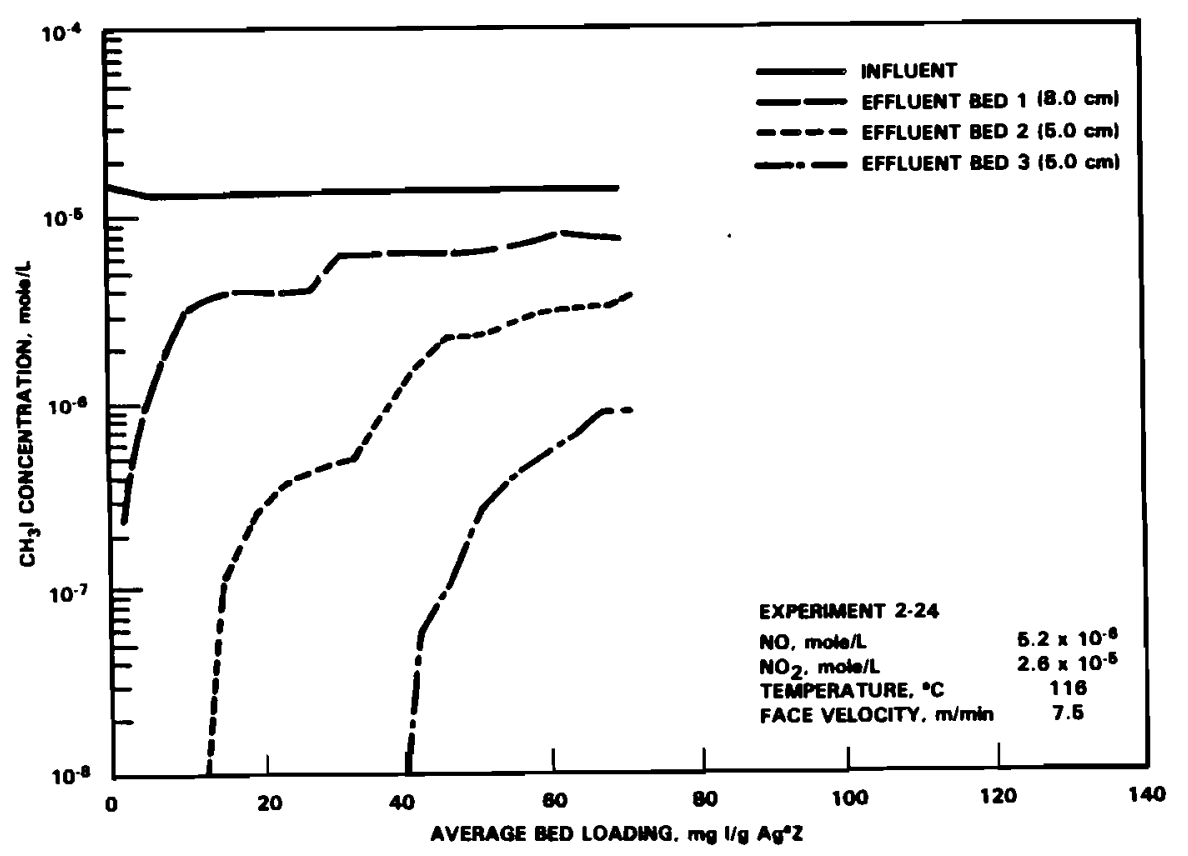

FIGURE A.24. $\mathrm{CH}_{3} \mathrm{I}$ Capture by $\mathrm{Ag}^{\circ} \mathrm{Z}$, Experiment 2-24 


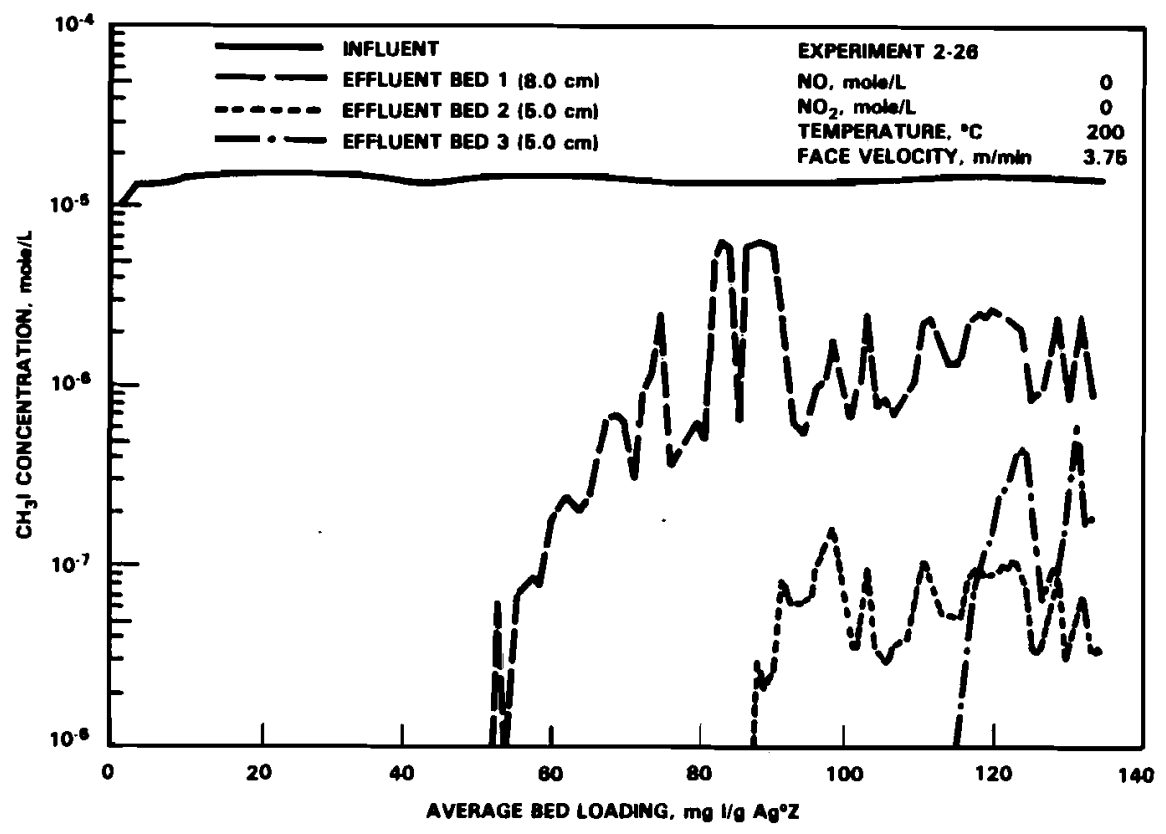

FIGURE A.25. $\mathrm{CH}_{3} \mathrm{I}$ Capture by $\mathrm{Ag}^{\circ} \mathrm{Z}$, Experiment 2-26

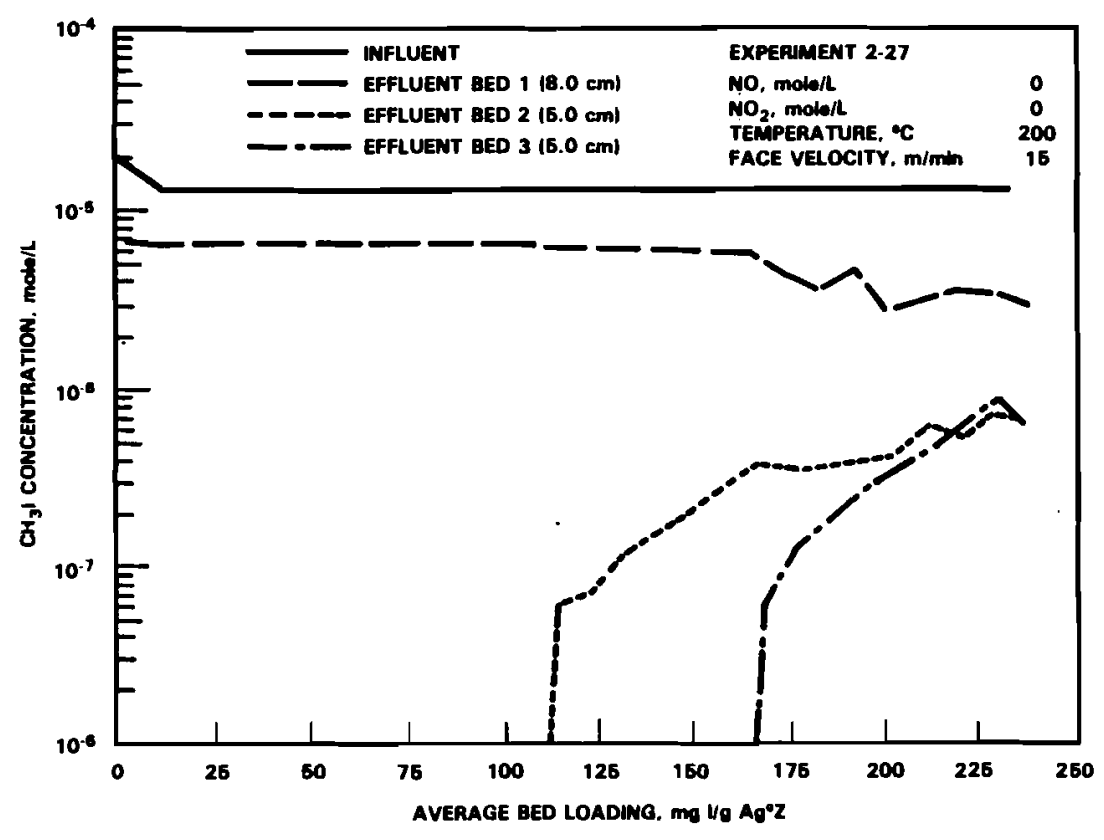

FIGURE A.26. $\mathrm{CH}_{3} \mathrm{I}$ Capture by $\mathrm{Ag}^{\circ} \mathrm{Z}$, Experiment 2-27 
$\therefore$ 


\section{DISTRIBUTION}

No. of

Copies

OFFSITE

27 DOE Technical Information Center

R. E. Cunningham

Office of Nuclear Safety

Materials and Safeguards

Room 562

Nuclear Regulatory Commission

7915 Eastern Avenue

Silver Springs, MD 20910

3 Division of Waste Management

Nuclear Regulatory Commission

Washington, DC 20555

ATTN: J. B. Martin

D. B. Rohrer

R. D. Smith

Materials Section Leader

High Level Waste Licensing Branch

Nuclear Regulatory Commission

Washington, DC 20555

W. E. Mott

DOE Division of Environmental

Control Technology

EV-13, GTN

Washington, DC 20545

3 DOE Office of Terminal Waste

Disposal and Remedial Actions NE30, GTN

Washington, DC 20545

Attn: F. E. Coffman

J. R. Coleman

J. A. Turi
No. of

Copies

4 DOE Office of Spent Fuel

Management and Reprocessing Systems

Washington, DC 20545

Attn: N. W. Ballard

C. B. Bastin

K. O. Laughon

W. H. McVey

3 DOE Office of Defense Waste and Byproducts Management

DP-12, GTN

Washington, DC 20545

ATTN: T. C. Chee

G. Dertel

R. D. Walton

2 Geologic Repository Division

Nuclear Waste Policy Act

Project Office: DOE

S-10 Forrestal Bldg.

Washington, DC 20585

ATTN: J. W. Bennett

M. J. Lawrence

C. R. Cooley

Geologic Repository Division

Nuclear Waste Policy Act

S-10/NE-22 GTN

Washington, DC 20585

Environmental Protection Agency

Technological Assessment Division (AW-559)

Office of Radiation Programs

Washington, DC 20460 
No. of

Copies

S. A. Mann

DOE Chicago Operations and

Region Office

Argonne, IL 60439

J. 0. Neff

DOE Columbus Program Office

$505 \mathrm{King}$ Avenue

Columbus, $\mathrm{OH} 43201$

3 DOE Idaho Operations Office

550 Second Street

Idaho Falls, ID 83401

Attn: J. P. Hamric

J. B. Whitsett

M. A. Widmayer

Office of the Assistant Manager

for Energy Research and

Development

DOE Oak Ridge Operations Office P. 0. Box E

Oak Ridge, TN 37830

3 DOE Savannah River Laboratory

P.0. Box A

Aiken, SC 29801

ATTN: E. S. Goldberg

T. B. Hindman

R. B. Whitfield

R. Y. Lowrey

DOE Albuquerque Operations Office

P. 0. Box 5400

Albuquerque, NM 87185

S. G. Harbinson

DOE San Francisco Operations Office

1333 Broadway

0akland, CA 94612
No. of

Copies

W. F. Holcomb

National Institute of Health

Radiation Safety Branch

Building 21

Bethesda, MD 20205

2 Allied-General Nuclear Services

P. 0. Box 847

Barnwell, SC 29812

ATTN: J. A. Buckham

A. Williams

2 Argonne National Laboratory

9700 South Cass Avenue

Argonne, IL 60439

ATTN: J. H. Kittel

M. J. Steindler/

L. E. Trevorrow

9 Battelle Memorial Institute

505 King Avenue

Columbus, $\mathrm{OH} 43201$

ATTN: S. H. Basham

A. Carbiener

N. E. Carter

J. 0. Duguid

S. Goldsmith

P. L. Hofmann

M. Kehnemuyi

J. F. Kircher

B. Rawles

2 EG\&G Idaho, Inc.

P. 0. Box 1625

Idaho Falls, ID 83415

ATTN: G. B. Levin

R. L. Tallman

R. Williams

Electric Power Research

Institute

3412 Hillview Avenue

P. 0. Box 10412

Palo Alto, CA 94304 
No. of

Copies

Exxon Nuclear Idaho

P. 0. Box 2800

Idaho Falls, ID 83401

ATTN: R. A. Brown

J. D. Christian

T. R. Thomas

6 0ak Ridge National Laboratory P.0. Box X

Oak Ridge, TN 37830

ATTN: J. 0. Blomeke

W. D. Burch

A. G. Croff

R. J. Jubin

R. G. Wymer

T. H. Row

7 E. I. duPont deNemours \& Co. Inc.

Savannah River Laboratory

Aiken, SC 29801

ATTN: H. H. Baker

M. D. Boersma

J. L. Crandall

S. D. Harris

D. L. Mc Intosh

S. Mirshak

S. W. O'Rear

E. Vejvoda

Rockwel1 International

Rocky Flats Plant

P. 0. Box 464

Golden, C0 80401

2 GA Technologies

P. 0. Box 81608

San Diego, CA 92138

ATTN: G. E. Benedict

W. S. Scheib, Jr.

J. L. Larocca, Chairman

Energy Research and Develop-

ment Authority

Empire State Plaza

Albany, NY 12223
No. of

Copies

2 Lawrence Livermore Laboratory

P. 0. Box 808

Livermore, CA 94550

ATTN: J. H. Campbell

W. G. Sutliff

3 Sandia Laboratories

Albuquerque, NM 87185

Attn: 0. E. Jones

R. G. Kepler

W. Weart

R. Roy

202 Materials Research Laboratory

University Park, PA 16802

J. R. Potter

Chem-Nuclear Systems, Inc.

P. 0. Box 1866

Bellevue, WA 98009

R. G. Post

College of Engineering

University of Arizona

Tucson, AZ 85721

W. A. Freeby

Bechtel Group, Inc.

Fifty Beale Street

P. 0. Box 3965

San Francisco, CA 94119

L. L. Hench

Dept. of Materials Science and Engineering

University of Florida

Gainesville, FL 32611

H. Palmour III

2140 Burlington Engineering Laboratories

North Carolina State University

Raleigh, NC 27607 
No. of

Copies

W. Tope

Westinghouse Electric

Corporation

Penn Center, Building 2

Box 355

Pittsburgh, PA 15230

ONSITE

4 DOE Richland Operations Office

P. F. X. Dunigan, Jr.

H. E. Ranson

J. J. Schreiber (2)

13 Rockwell Hanford Operations

J. L. Deichman

J. 0. Honeyman

L. Jensen

J. E. Kinser

H. G. McGuire

R. M. Orme

J. Reser

J. H. Roecker

W. W. Schulz

R. E. Van der Cook

D. G. Wilkins

G. D. Wright

File Copy

2 UNC United Nuclear Industries

F. H. Bouse, Document Control

T. E. Dabrowski

Westinghouse Hanford Company

3 A. G. Blasewitz

R. E. Lerch

J. J. McCown
No. of

Copies

67 Pacific Northwest Laboratory

W. F. Bonner

F. P. Brauer

L. A. Bray

L. L. Burger (15)

T. D. Chikalla

C. R. Hann

0. F. Hill

J. H. Jarrett

A. B. Johnson, Jr.

S. E. King

M. R. Kreiter

L. T. Lakey

R. C. Liikala

R. P. Marshall

E. D. McClanahan

J. L. MCEl roy

J. E. Mende 1

I. C. Nelson

J. M. Nielsen/R. W. Perkins

R. E. Nightingale

A. M. Platt

W. A. Ross

J. M. Rusin

R. D. Scheele (15)

J. K. Soldat

J. L. Swanson

G. L. Tingey

C. L. Unruh

H. H. Van Tuyl

E. C. Watson

E. J. Wheelwright

W. R. Wiley

Technical Information (5)

Publishing Coordination (2) 